\title{
Central Bank Reputation and Inflation-Unemployment Performance: Empirical Evidence from an Executive Survey of 62 Countries
}

In Do Hwang*

The views expressed herein are those of the authors and do not necessarily reflect the official views of the Bank of Korea. When reporting or citing this paper, the authors' names should always be explicitly stated.

* Senior Economist, Micro \& Institutional Economics Team, Economic Research Institute, The Bank of Korea, Tel: +82-2-759-5366, E-mail: hid@bok.or.kr.

I thank Sung Ju Song, Dongweon Lee, Ki Ho Kim, Byoung-Ki Kim, and an external reviewer of the BOK Working Paper Series for valuable comments and suggestions. This paper also benefited from the discussions at the Bank of Korea Seminar (July 2017). 


\section{Contents}

I . Introduction ………………………………………………... 1

II. Literature on Central Bank Reputation and Credibility .. 5

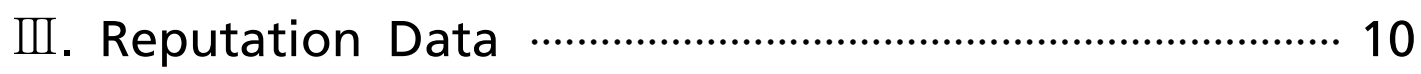

IV. Empirical Analysis ………………………………………... 16

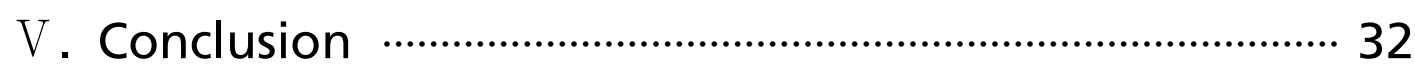

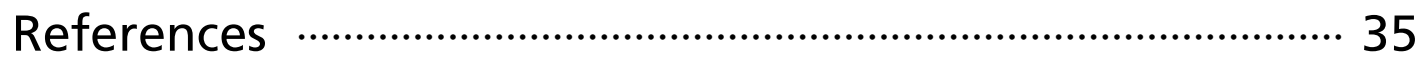

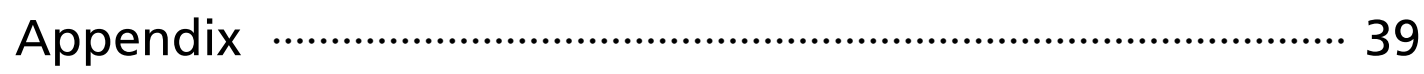




\section{Central Bank Reputation and Inflation-Unemployment Performance: Empirical Evidence from an Executive Survey of 62 Countries}

Although there is a well-established theoretical literature that links central bank (CB) reputation with inflation performance following Barro and Gordon, there is little empirical work testing the relationship rigorously. This paper empirically tests the impact of reputation on inflation-unemployment performance using a novel set of data on CB reputation - an annual local business manager survey on central bank policy covering 62 countries during 1995-2016. This paper finds that CB reputation is a significant determinant of inflation: the results of an FE panel and Arellano-Bond difference GMM model show that high-reputation $\mathrm{CBs}$ have achieved better inflation performances over the past 20 years with lower levels of inflation than others, holding the output gap and unemployment rate constant. This result remains robust to various control variables including money growth, past inflation levels, exchange rates, and financial crisis dummies. This paper also finds that high $\mathrm{CB}$ reputation is associated with a tight anchoring of inflation expectations to inflation targets in inflation-targeting countries. The effects of reputation on the volatility of inflation and unemployment rates are found to be not robust. This paper offers evidence of the opposite-direction causality as well that goes from high inflation to decreased $\mathrm{CB}$ reputation.

Keywords: Reputation, Credibility, Monetary policy, Anchoring of inflation expectation

JEL Classification: E31, E52, E58, N10 


\section{I . Introduction}

Central bank (CB) reputation is a key element in the literature on monetary policy. In their seminal work, Barro and Gordon (1983) consider an economy where a $\mathrm{CB}$ has an incentive to create surprise inflation to stimulate the economy, and show that in a repeated game reputational forces may prevent the CB from generating an inflation surprise. Barro (1986) provides a formal definition of reputation in a subsequent study: private agents' subjective perceptions of the monetary authority's type-whether the monetary authority is committed to low inflation. A closely related notion, credibility, has been defined as follows: "A central bank is credible if people believe it will do what it says" (Blinder, 2000, p. 1,422). The difference between reputation and credibility is that reputation refers to the type of central bank -inflation fighter or not- while credibility is related to a shift in the policy target -if an announced inflation target shifts inflation expectations immediately. For example, Barro (1986) notes that credibility of a policy is affected by the reputation of the $\mathrm{CB}$.

There are, however, few empirical studies that attempt to measure CB reputation and quantify its effects on macro economy. Virtually all prior empirical studies focus on credibility. These studies measure credibility using (i) the deviation of actual inflation or inflation expectations from the inflation target (Cecchetti \& Krause, 2002; Mariscal, 2011; Bordo \& Siklos, 2015; Levieuge et al., 2015) or (ii) interest rates, which reflect private agents' expectations about the CB's policy response (Goldberg \& Klein, 2010). Although these studies are extremely valuable and carefully written, the measures they use may not capture credibility successfully because of the challenge in identifying whether changes in inflation expectations or interest rates are actually caused by private agents' trust in $C B$ policy or other factors affecting inflation or interest rates. That is, since expectations about future business conditions also affect inflation expectations and market interest rates, it can be tricky to separate out the 
contribution of credibility (Kril, Leiser \& Spivak, 2016).

As real-world reputation data are not available, two studies take an experimental approach to examine the role of $\mathrm{CB}$ reputation in laboratory settings. The results are mixed: While Arifovic and Sargent (2003) find that reputational forces emerge and alleviate the inflation bias in a Barro-Gordon game, Duffy and Heinemann (2016) do not find any effect of reputation.

This paper introduces a novel data set that can measure CB reputation among business leaders and investigates how the reputation affects macroeconomic performance in a cross-section and a panel of countries. This paper uses an annual executive opinion survey conducted by the International Institute for Management Development (IMD), which covers 62 countries for the period 1995-2016. The survey asks respondents to evaluate the following statement: "Central bank policy has a positive impact on economic development" (0-10 scale, a high figure means a high reputation).

In section III, this paper explores whether the IMD measure is a reliable proxy for $\mathrm{CB}$ reputation and concludes that the IMD measure is indeed an acceptable proxy for actual reputation. To explore this issue, the section first compares the IMD measure with the large survey conducted by the Bank of England (BOE) regarding public attitudes toward the BOE's handling of policy rates and inflation. Secondly, the section also examines whether the IMD measure, which only surveys firm managers, is biased toward expansionary monetary policy. Thirdly, the section further examines whether the IMD measure has a theoretically correct relationship with the $\mathrm{CB}$ independence index (+), past inflation level (-), and other variables.

Using the direct measure of reputation, this paper examines the following research questions, which have not been empirically investigated in the literature:

[H1. Barro-Gordon Hypothesis (a): Reputation $\Rightarrow$ Inflation \& Unemployment] Barro and Gordon's (1983) reputational equilibrium 
model suggests that $\mathrm{CB}$ reputation is a key determinant of inflation expectations and realizations. Does $C B$ reputation really stabilize inflation holding the level of unemployment constant as the Barro-Gordon model suggests?

[H2. Barro-Gordon Hypothesis (b): Inflation \& Unemployment $\Rightarrow$ Reputation] Can we observe the private sector's punishment of CBs who break their price stability commitments? While the definitive answer to this question may not be derived from the data set in this paper, the following modified question will help draw a broad conclusion: Does high inflation (relative to a given unemployment rate) really lower $C B$ reputation?

[H3. Barro-Gordon Hypothesis (c): Reputation as a Substitute for Formal Rules] If reputation is a substitute for formal monetary policy rules as Barro and Gordon (1983) claim, the effect of reputation on inflation-output performance should be large among those countries without commitment mechanisms such as IT. Can we observe a larger impact of reputation on inflation outcomes in non-IT countries than IT countries?

\section{[H4. Faust-Svensson Hypothesis: Significant Role of Reputation} Even in a Low-inflation Environment] Does reputation remain an important determinant of economic outcomes in an economy that has solved the inflation bias problem and already reached a low-inflation steady-state? Faust and Svensson (2001, pp. 380-381) explore this issue and conclude that reputation may remain an important factor even in a low-inflation economy, as characterized by economies whose equilibrium inflation rates are never above 5 percent, based on the numerical solutions of their model. Verifying their calibration result using historical data is particularly valuable considering that many advanced economies have entered a low-inflation and low-growth stage since the 2008 global financial crisis.

Regarding the main research question ( $\mathrm{H1})$, this paper finds that CBs with high reputations have recorded better inflation performances over the past 20 years with lower levels of inflation than others, holding the level of output gap and unemployment rates constant. This paper 
employs three econometric methods: (i) a cross-section analysis to examine the "between" effects of reputation across 62 countries (OLS and 2SLS), (ii) a fixed effect panel model to explore "within" effects of reputation across different times, and (iii) Arellano-Bond's (1991) difference GMM model to resolve the endogeneity problem. Estimation results from the three methods show that countries with high-reputation CBs indeed have recorded significantly lower levels of inflation. The results remain robust to the inclusion of various control variables such as the output gap, unemployment rates, exchange rates, financial crisis dummies, and the IT adoption dummy, and to data frequency (3-year averaged data vs. annual data). This paper also finds that high CB reputation is associated with a tight anchoring of inflation expectations to inflation targets in IT countries. Regarding the second research question $(\mathrm{H} 2)$, this paper finds that high inflation and unemployment rates lead to low reputation in regression results of the FE panel and Arellano-Bond's Difference GMM. Overall, the results on $\mathrm{H} 1$ and $\mathrm{H} 2$ suggest that there exists a two-way causal relationship between inflation performance and $\mathrm{CB}$ reputation. Regarding the third research question (H3), this paper finds evidence in support of the hypothesis: the impact of reputation is large in non-IT countries (those that do not have an explicit commitment device) in the cross-sectional analysis. Regarding the fourth hypothesis (H4), this paper finds that reputation is a statistically significant determinant of inflation in those countries whose inflation rates are never above 5 percent during 1995-2016, which exemplifies the importance of reputation in a low inflation environment.

This paper is organized as follows. Section II summarizes the related literature. Section III introduces the survey on CB policy and examines whether the survey results are valid proxies for $\mathrm{CB}$ reputation. Section IV conducts an empirical analysis to test the four hypotheses. Section V concludes. 


\section{Literature on Central Bank Reputation and Credibility}

\section{Definition}

\section{Reputation}

Barro and Gordon (1983) focus on the repeated interactions between the policymaker and private agents with rational expectations. The study shows that reputation - the monetary authority's reputation for "not cheating" - can substitute for formal monetary policy rules. Barro and Gordon observe that if private agents rationally expect that the $\mathrm{CB}$ has incentives to generate surprise inflation in order to enjoy temporarily low unemployment (which tends to be seen in a policy regime that is discretionary rather than rule-based), then this leads to a high-inflation and low-welfare equilibrium. However, reputational forces in a repeated game (the CB's incentives to maintain a high reputation among private agents), Barro and Gordon note, may resolve the inflation bias problem even in a discretionary policy regime if the $\mathrm{CB}$ places an appropriate weight on future welfare.

Barro (1986) defines reputation as private agents' subjective perceptions of the monetary authority's type-whether the monetary authority is committed to low inflation. Faust and Svensson (2001) also relate reputation to the public's guess as to the CB's preference for (low) inflation and employment in a circumstance where the public cannot observe the policymaker's true preference. In Faust and Svensson's model, the CB's true preference is summarized by a loss function, $L_{t} \equiv \pi^{2}+\left[l_{t}-\left(l^{*}+z_{t}\right)\right]^{2}$. The terms $l_{t}$ and $l^{*}$ imply actual employment at period $t$ and the long-run socially optimal level of employment, respectively. The term $\left(l^{*}+z_{t}\right)$ represents the CB's implicit employment target for period $t$. The implicit employment target $\left(l^{*}+z_{t}\right)$ can be higher than the socially optimal level $\left(l^{*}\right)$ and the deviation (or 
employment surprise) is denoted by $z_{t}$. The public's guess regarding the deviation, $z_{t \mid t-1}$, defines an inverse of reputation. In other words, if the public believes that the $\mathrm{CB}$ has an implicit employment target (or inflation target) in excess of the socially desirable level, this implies that the CB has a low level of reputation.

\section{Credibility}

A closely related notion is CB credibility. Blinder (2000) points out that there is "no generally agreed-upon definition" of credibility, while reporting that his favorite definition is as follows: "A central bank is credible if people believe it will do what it says" (p. 1,422). He notes that credibility is often defined in various ways in the literature: sometimes it means "strong aversion to inflation," and other times it implies the "incentive compatibility" of monetary policy. He explains these definitions using the loss function of a $\mathrm{CB}, L_{t}=\left(u_{t}-k u_{t}^{*}\right)^{2}+\alpha \pi_{t}^{2}$. Blinder states that some researchers believe that credibility is simply the parameter of inflation aversion, $\alpha>0$, (large $\alpha$ means high credibility), while other researchers think that credibility implies a low temptation to cheat, which is determined by $k<1$ (so that $\mathrm{CB}$ commitments are incentive compatible). Faust and Svensson (2001) define credibility rather simply: the "credibility of the zero-inflation announcement in period $t-1$ " is "the negative of the absolute value of the deviation of inflation expectations from zero" (i.e., credibility $y_{t-1} \equiv-\left|\pi_{t \mid t-1}\right|$ ) (p. 373).

\section{Reputation vs. Credibility}

Most of the above-mentioned studies, including Barro (1986) and Bordo and Siklos (2014), use the terms reputation and credibility almost interchangeably. The difference, although subtle, is that reputation refers to the "type" of "central bank" (inflation fighter or not) while credibility is related to the "shift" in the "policy target" (if an announced inflation 
target shifts inflation expectations immediately). For example, Barro (1986) notes that the credibility of policy is affected by the reputation of the $\mathrm{CB}$ - whether the $\mathrm{CB}$ is a "type 1" policymaker committed to low inflation. Similarly, in Faust and Svensson's (2001) model, reputation $\left(-z_{t \mid t-1}\right)$ and credibility $\left(-\left|\pi_{t \mid t-1}\right|\right)$ are closely linked by the Phillips curve.

\section{Empirical and Experimental Literature}

\section{Empirical Study on CB Credibility}

To my knowledge, there is no empirical study on the macroeconomic effects of $\mathrm{CB}$ reputation. Most prior empirical studies focus on the role of credibility. The studies measure credibility using (i) the deviation of actual inflation or inflation expectations from the inflation target (for example, Cecchetti and Krause, 2002) or (ii) yield curves which reflect perceived policy responses of a CB (Goldberg \& Klein, 2010). These measurement strategies are based on Cukierman and Meltzer's (1986) definition of monetary policy credibility: "Credibility is defined as [an inverse of] the absolute value of the difference between the policymaker's plans and the public's beliefs about those plans." Bordo and Siklos (2015) measure credibility as an inverse of the squared deviation of actual inflation rates from the implicit inflation target and find that (i) $\mathrm{CB}$ credibility changes substantially over time; (ii) its fluctuation depends largely on institutional factors such as the monetary policy regime in place (e.g., the gold standard) and CB independence; and (iii) economic crises lower credibility. In a concurrent study, Bordo and Siklos (2014) further find that adoption of IT has significantly improved CB credibility. Levieuge et al. (2015) measure credibility using the "gap between inflation expectations and the official inflation target," and find that credibility decreases the volatility of short-term interest rates ${ }^{1)}$. Mariscal et al. (2011)

1) A large gap implies a low level of credibility. 
use a similar measurement approach and find that the BOE's credibility increased in 1992 with the adoption of explicit IT and has decreased since 2007 with the onset of financial crisis. Blinder (2000) conducts a survey targeting central bankers and economists around the world and reports that "a history of doing what it says it will do" can be the most important factor for a central bank to establish credibility.

\section{Empirical Literature on Trust in the Central Bank}

A line of research explores the determinants of public trust in CBs using individual-level survey data (Fischer \& Hahn, 2008; Ehrmann, Soudan \& Stracca, 2012; Wälti, 2012; Bursian \& Fürth, 2015). The literature uses the item in the Eurobarometer survey, "[P]lease tell me if you tend to trust [the European Central Bank] or tend not to trust it. (1) Tend to trust; (2) Tend not to trust; (3) Do not know," and measures trust by the share of the population who answer "(1) Tend to trust." Bursian and Fürth (2015) find that trust in the ECB drops significantly in most of the EMU countries during 1999-2010. They report that individual socioeconomic characteristics and macroeconomic conditions such as GDP growth rates (+), unemployment rates (-), government debt (-), and inflation deviation (-, only partially significant) affect the level of trust in the ECB. Ehrmann, Soudan and Stracca (2012) report that demographic factors, economic conditions (unemployment rates and financial crisis dummy variables), attitudes toward EU membership, and the level of knowledge about the ECB are significant determinants of trust in the ECB. Fischer and Hahn (2008) report that the probability of trusting the ECB is negatively associated with inflation rates and positively with national income.

Kril, Leiser and Spivak (2016) differentiate between general trust in the $\mathrm{CB}$ and the credibility of $\mathrm{CB}$ forecasts. The study measures general trust in the Bank of Israel by asking respondents to evaluate the following statement: "The Bank of Israel is trustworthy compared with 
other institutions $[1=$ Not at all, $6=$ Very much $] . " \quad$ The credibility of the economic forecasts of the bank is measured by using the following question: "Assume the Bank of Israel expects the CPI to rise in a particular year between 5 and 6 percent. Please rate on a scale of 1 to 9 , to what extent do you believe that the Bank's forecast will be realized and will the CPI will indeed fall in this range?." The study finds that general trust in the $\mathrm{CB}$ is closely related to the credibility of the bank's economic forecasts. The study further shows that general trust in the $\mathrm{CB}$ is determined by the respondents' assessment of the "professionalism" and "independence" of the CB.

A recent work by Christelis et al. (2016) examines the effects of trust in the ECB on inflation expectations using survey data for Dutch individuals. The study measures trust by asking, "How much do you trust the European Central Bank (ECB)? Please indicate your level of trust on a scale from 0 to 10 , where 0 means you cannot trust at all and 10 means that you fully trust." The study finds that stronger trust in the ECB lowers inflation expectations, increases growth expectations, and reduces uncertainty about future inflation. The study also finds that the more the respondents trust the $\mathrm{ECB}$, the better-anchored their inflation expectations are to the ECB inflation target.

\section{Experimental Studies on CB Reputation}

Two studies take an experimental approach to examine if reputation can alleviate inflation bias in a laboratory setting. The results vary depending on the settings of the experiment: one of the studies finds that reputational forces emerge and alleviate the inflation bias (Arifovic \& Sargent, 2003), while the other study does not find any effect of reputation (Duffy \& Heinemann, 2016).

Arifovic and Sargent (2003) conduct a so-called Barro-Gordon game. Subjects (undergraduate students) are divided into two groups: policymakers and private sector forecasters. Forecaster-role subjects are asked to forecast the next period's inflation, and their payoff is designed to decrease as 
their forecast error widens. Policymaker-role subjects are asked to choose the current period's inflation rate given the private forecasters' inflation expectations formed in the previous period. Their payoffs are similar to an inverse of the CB loss function (a decreasing function of the squared sum of the inflation and unemployment rates). In order for the game to mimic an infinite horizon game, Arifovic and Sargent conduct 12 experiments with up to 100 sessions per experiment. They find that policymaker-role subjects push inflation down to a socially desirable level in nine out of the twelve experiments. This result supports the hypothesis that reputational forces do work to lessen inflation bias.

Duffy and Heinemann (2016) conduct a similar Barro-Gordon game, but they do not find evidence of the reputation effect. They observe a significant inflation bias in a discretionary policy regime and conclude that "reputation is a poor substitute for commitment" (abstract). The experiment settings of Duffy and Heinemann differ from those of Arifovic and Sargent (2003) in two key respects. First, while Arifovic and Sargent informed subjects that they were playing a monetary policy game, Duffy and Heinemann did not, instead framing the game in terms of moving water from one container to another to imply the trade-off between inflation and unemployment. Second, in contrast to Arifovic and Sargent, Duffy and Heinemann informed subjects of the payoffs to counterpart players.

\section{Reputation Data}

\section{IMD Executive Opinion Survey on Central Bank Policy}

This paper uses an annual executive opinion survey conducted by the International Institute for Management Development (IMD), which covers a maximum of 62 countries for the period 1995-2016. The following sentence is one of the survey items, which has been published in the World Competitiveness Yearbook. 
"Central bank policy has a positive impact on economic development."

(1-2-3-4-5-6)

Disagree Agree

The IMD converts the average rates to a 0-10 scale by the following formula: “average rating *2-2." This paper uses $0-10$ scale data. Responses to the above question seem to match well with the definition of reputation in Faust and Svensson (2001), who define it as private agents' belief that the $\mathrm{CB}$ is pursuing the optimal inflation and employment target minimizing the social loss function. The IMD explains the survey measure as follows:

"The Executive Opinion Survey is sent to mid- and upper-level managers in all the economies studied. The sample of respondents is representative of the entire economy, covering a cross-section of the business community in all economic sectors. In order to be statistically representative, we select a sample size that is proportional to the GDP breakdown of economic sectors of the economy. The survey respondents are nationals or expatriates, in domestic or international enterprises who have resided at least a year in the economy under consideration. They are asked to evaluate the present and future competitiveness conditions of the economy in which they work, drawing from their domestic and international experience." (IMD webpage,2) 2017, all bolds are mine)

In 2016, approximately 5,400 executives responded to the survey. Therefore, the reputation measure of a country in 2016 is based on, on average, the responses of 87 local executives. The trend of the reputation measure for 62 countries is presented in Figure 1. The average and median reputations of the 62 countries are presented in Figure Al (Appendix). The level of reputation tends to show a declining trend in most countries. Reputation exhibits a significant drop with the onset of economic crises such as the collapse of the "dot-com" bubble in 2000 and

2) Retrieved from http://www.imd.org/globalassets/wcc/docs/methodology_world_competitiveness_center.pdf 
Figure 1. Central Bank Reputation Data

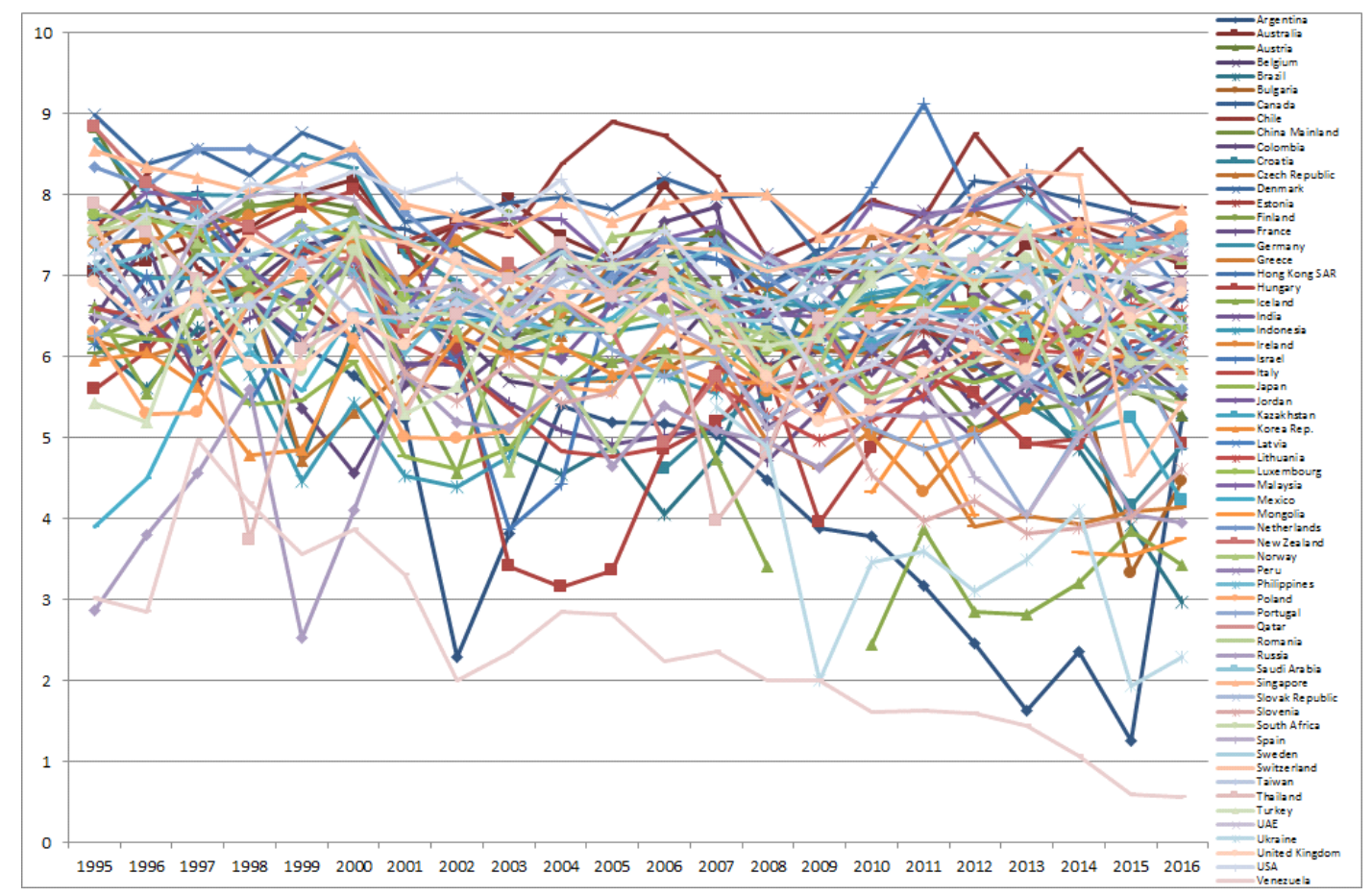

Source: IMD, World Competitiveness Yearbook (1995-2016), Executive Opinion Survey on "central bank policy." The data has 0-10 scale. A high value means a positive perception of CB policy.

the global financial crisis in 2008. The two patterns -the downward trend since the late 1990 s and the sharp fall during the crisis period- are also observed in $\mathrm{CB}$ credibility measures derived from inflation expectations (Bordo \& Siklos, 2014), in the measure for trust in the ECB derived from the Eurobarometer survey (Bursian \& Fürth, 2015), and in the net satisfaction measure regarding the Bank of England's handling of interest rates and inflation (see Figure 2).

By country, the CBs of Chile (7.84), Singapore (7.82), Poland (7.59), and New Zealand (7.54) received high scores in 2016, whereas the CBs of Iceland (3.43), Brazil (2.96), Ukraine (2.29), and Venezuela (0.56) recorded low marks. 


\section{Is the IMD Reputation Data a Reliable Measure for CB Reputation?}

The IMD reputation data has several limitations. First, the IMD only surveys business managers. Hence, the survey result basically reflects the views of producers, not consumers, with respect to $\mathrm{CB}$ policy. This in turn draws concerns that the reputation measure is biased toward inflationary pressure because firms and managers may benefit from increases in product prices. Similarly, the reputation measure may be biased toward expansionary monetary policy as expansionary policy can be beneficial to firms' earnings. Second, the sample size of respondents is small (the reputation measure for a CB in 2016 is based on, on average, the responses of 87 executives). Hence the survey result is not representative of the opinions of all firm managers. Since respondents may change from year to year, the reputation measure can be affected by the characteristics of respondents.

Although the reputation measure has some limitations by construction, a close look at the data reveals that it is an acceptable proxy for $\mathrm{CB}$ reputation.

First, the reputation measure of this paper is not systematically different from the opinion of the general public, including consumers. Figure 2 compares the trend of the IMD reputation data for the UK with results of the BOE's Inflation Attitudes Survey. When conducting the Inflation Attitudes Survey, the BOE asks respondents how well they think the bank is doing its job. Specifically, the survey item is as follows. "Overall, how satisfied or dissatisfied are you with the way the Bank of England is doing its job to set interest rates in order to control inflation?" Representative samples of more than 2,000 UK individuals aged 16 and over are interviewed in the BOE survey. The dotted line in Figure 2 represents the percentage of those "satisfied" less those "dissatisfied." The net satisfaction percentage may be a good proxy for the reputation of the BOE. 
Figure 2. IMD Reputation Measure for BOE vs. BOE' s Large Survey Results on Public Satisfaction with BOE's Handling of Interest Rates and Inflation

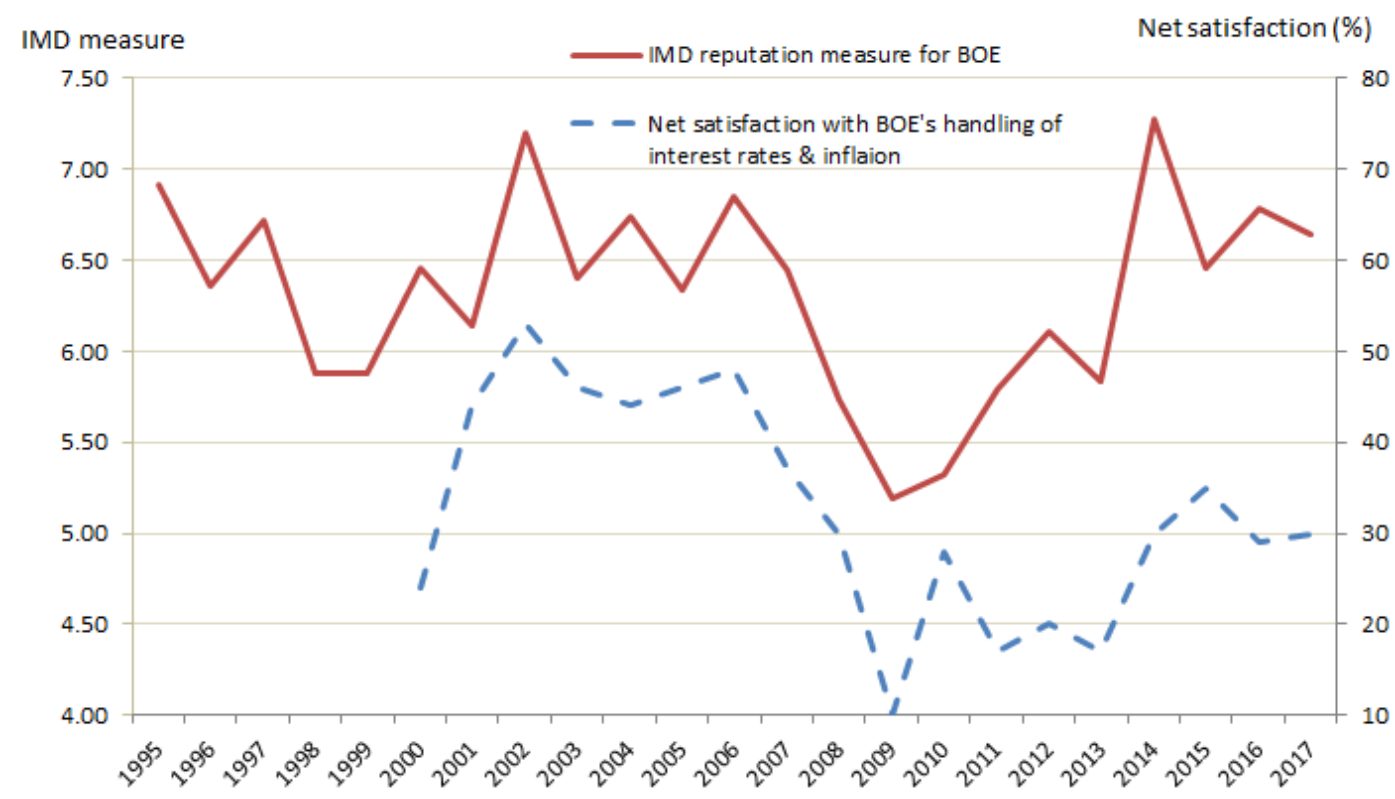

Source: IMD, World Competitiveness Yearbook; Bank of England, Inflation Attitudes Survey

Notes: BOE's survey question is as follows: "Overall, how satisfied or dissatisfied are you with the way the Bank of England is doing its job to set interest rates in order to control inflation?" The BOE surveys more than 2,000 people.

Although there are differences between the IMD survey and the BOE survey in terms of respondents (firm executives vs. general public), sample size (87 vs. 2,000), and focus (positive impact on economic development vs. control of inflation), the results of the two surveys appear to be not systematically different. The similarity of the trends in Figure 2 suggests that the IMD reputation measure may be an acceptable proxy for CB reputation in conducting monetary policy.

Secondly, the trends in Figure A2 (Appendix) indicate that the IMD data are not systematically biased toward expansionary monetary policy. The left panel of Figure A2 presents the IMD reputation data for the US and the federal funds rate, while the right panel shows the data for the ECB and its policy rate. The left panel shows that although Fed lowered its policy rate during 2000-2004 and 2008-2010, the reputation measure 
for the Fed decreased. Similarly, although the ECB cut its policy rate during 2001-2003, its reputation among German executives worsened. These patterns suggest that the direction of monetary policy (expansionary vs. contractionary) may not be a dominant determinant of reputation.

Thirdly, the IMD reputation measure has a reasonable (theoretically correct) relationship with the $\mathrm{CB}$ independence index (+), past inflation rates (-), past unemployment rates (-), and an indicator variable for adopting IT (+). Literature on reputation (Barro \& Gordon, 1983; Barro, 1986), credibility, and CB independence (Cukierman et al., 1992; Alesina and Summers, 1993; Arnone et al., 2007; Crowe and Meade 2008) suggests that $\mathrm{CB}$ independence should have a positive effect on reputation. The scatter plot in Figure A3 (Appendix) is in line with this argument. It illustrates that CBs reputation is low in countries which experienced frequent changes (high turnover rates) of $\mathrm{CB}$ governors. Although outliers seem to affect the linear regression line in the figure, even when quantile regression is employed, one can get similar results: high turnover rates result in low reputation (See Figure A4). Since virtually all $\mathrm{CBs}$ principally pursue stable prices and sustainable growth (or maximum employment), CB reputation should be negatively associated with past inflation, and positively with past growth rates. The introduction of IT may enhance CB credibility and the effectiveness of monetary policy (Gonçalves \& Carvalho, 2009) and therefore may have positive impacts on CB reputation. Cross-sectional OLS regression results in Table A3 show that the reputation measure from IMD has a reasonable relationship with past inflation (-), unemployment rates (-), communication as measured by the average number of $\mathrm{CB}$ speeches per month during 1998-2014 (+), and the dummy variable for adopting IT as of $1999(+)$. The negative association between past inflation and $\mathrm{CB}$ reputation is consistent with the prediction of $\mathrm{H} 2$. The second hypothesis will be fully examined in the panel data analyses. 


\section{Empirical Analysis}

\section{Cross-sectional Analysis}

The main empirical model for $\mathrm{H} 1$ and $\mathrm{H} 2$ is as follows:

$$
\begin{aligned}
\text { INFLATION }_{i}=\alpha & +\beta_{1} \text { REPUTATION }_{i}+\beta_{2} I T_{i} \\
& \times \operatorname{REPUTATION}{ }_{i}+\beta_{3} I T_{i}+\gamma X_{i}+\epsilon_{i}
\end{aligned}
$$

where $I T_{i}$ is an indicator variable for adopting IT, and $X_{i}$ is a set of control variables.

Details of the data set are explained in Table A2 (Appendix). Following the literature standard, this paper uses transformed values of inflation to reduce heteroskedasticity (Cukierman et al., 1992; Crowe \& Meade, 2008). The main dependent variable INFLATION is ' $\pi /(100+\pi)$ ', where $\pi$ is the annual inflation rate of CPI during 2000-2016 (for example, if $\pi$ is 2 percent, then INFLATION is 0.0196). Other dependent variables are standard deviation (S.D.) of INFLATION and UNEMPLOYMENT RATE (average during 2000-2016). For a main explanatory variable, a predetermined value of REPUTATION (i.e., average over 1995-1999) is used to reduce the reverse causality problem.

Figures 3 and 4 indicate that a high reputation is associated with low levels of subsequent inflation and low variability of inflation. They illustrate that the average inflation rate (transformed values) during 2000-16 and its standard deviation are negatively correlated with REPUTATION during 1995-99. Figure 5 indicates that unemployment rates are only weakly negatively correlated with the past reputation. 
Figure 3. Reputation and Inflation (Cross-section)

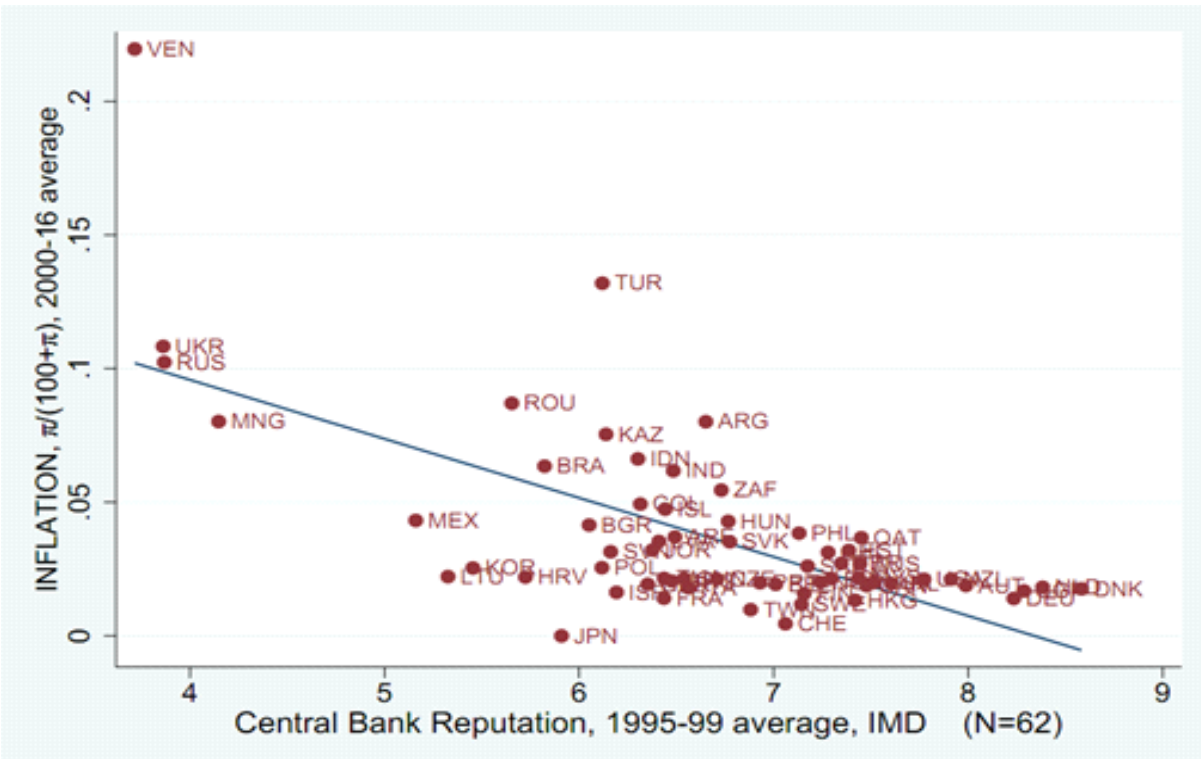

Note: The $\mathrm{Y}$-axis is the transformed value of the inflation rate $(\pi)$. If $\pi=5$ percent, then INFLATION is 0.0476 . The linear regression line does not change substantially when potential outliers such as VEN and TUR are removed.

Figure 4. Reputation and Standard Deviation of Inflation (Cross-section)

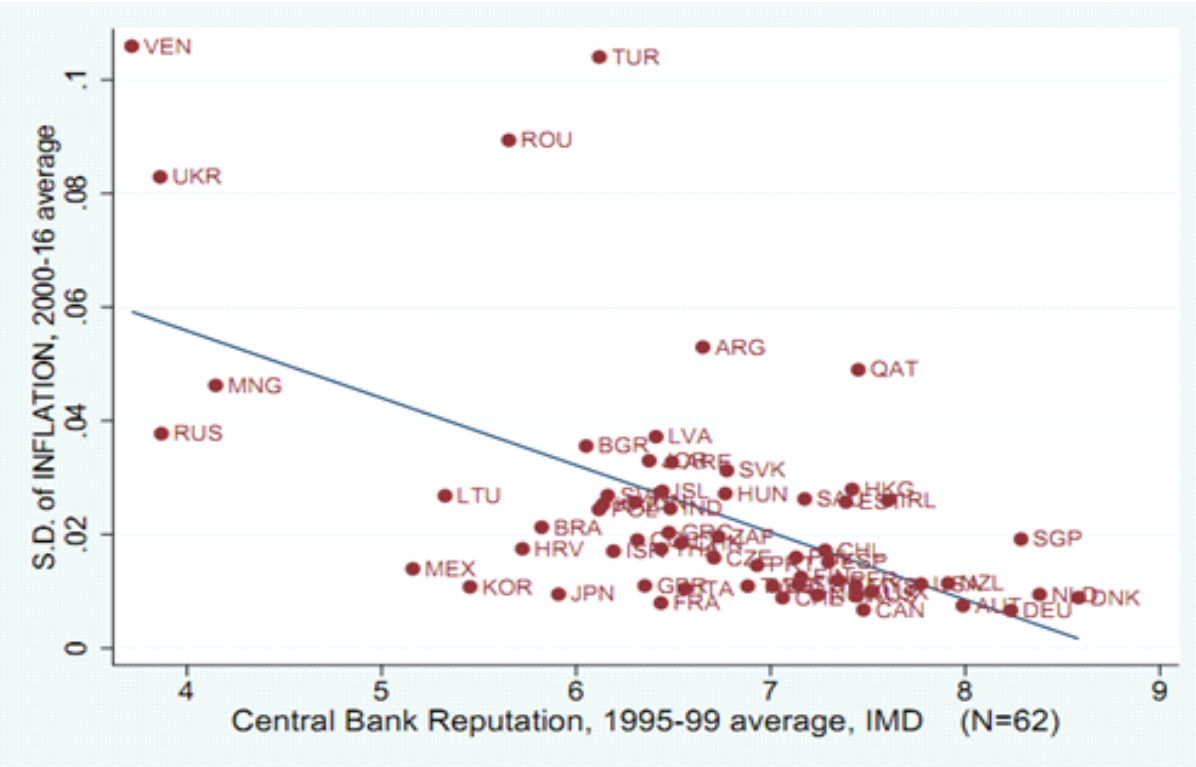

Note: The linear regression line does not change substantially when potential outliers such as VEN and TUR are removed. 
Figure 5. Reputation and Unemployment Rate (Cross-section)

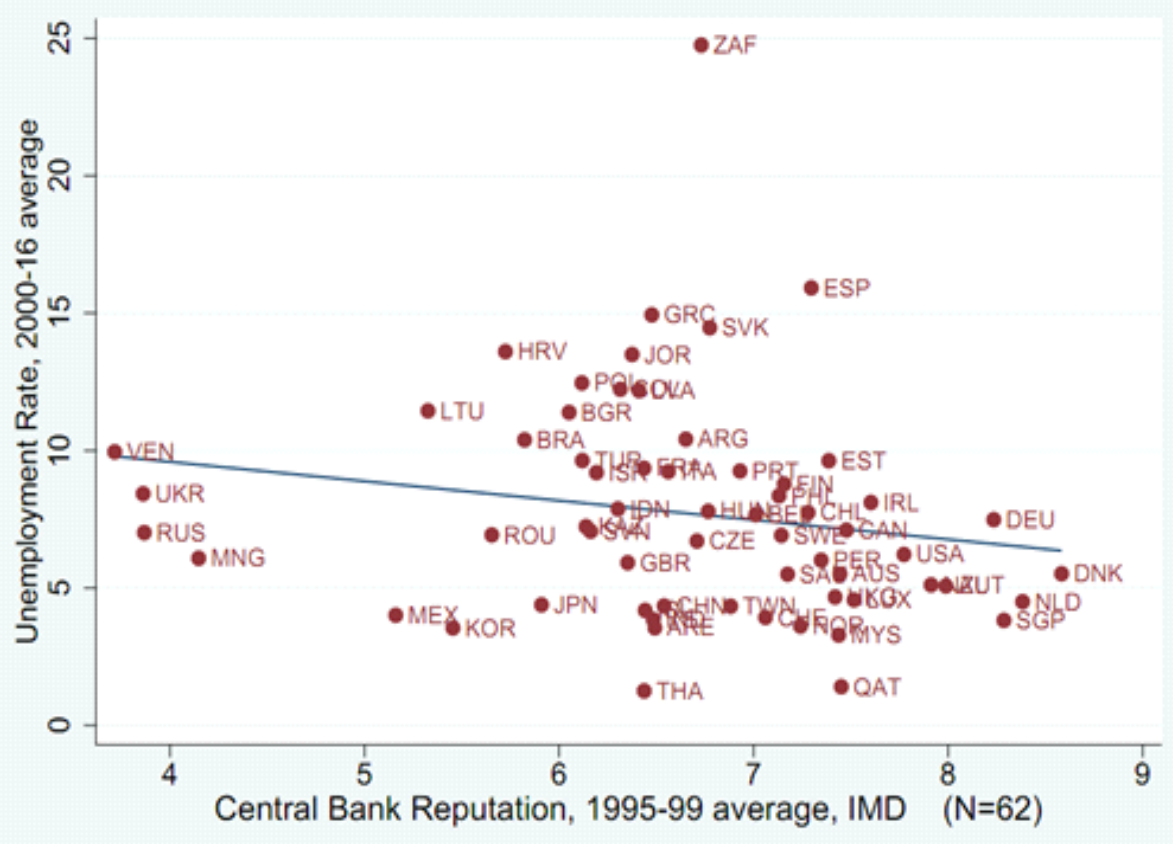

The regression results in Panel A of Table 1 suggest that CB reputation may stabilize inflation and the stabilizing effect is larger in non-IT than IT countries, supporting $\mathrm{H1}$ and H3. The cross-sectional OLS results in columns (1)-(3) indicate that a one point increase in REPUTATION (average during 1995-99) is associated with a 0.0192 0.0221 fall in average INFLATION during 2000-16 for non-IT countries (an approximately two percent point decrease in annual CPI inflation), suggesting that reputation has economically meaningful effects on inflation levels. One can verify that the results are similar when various control variables are included, such as the dummy variable for adopting IT as of 1999, growth rates, openness, per capita GDP, past levels of inflation, and regional dummies for East Asia, Latin America, Nordic countries, and the euro area. ${ }^{3)}$ Significant negative coefficients of the INFLATION TARGETING_1999 term suggest that countries that adopted IT achieved

3) The reason for including these control variables is explained in the panel data analysis. 
lower inflation rates than others. Significant positive coefficients of the interaction term, REPUTATION(1995-99) $\mathrm{x}$ INFLATION TARGETING _1999, indicate that the inflation-stabilizing effect of reputation is small in IT countries (those that have an alternative commitment mechanism other than reputation), consistent with $\mathrm{H} 3$.

The results in columns (4)-(6) of Panel A of Table 1 show that a one point increase in REPUTATION is associated with a $0.0105 \sim 0.0134$ decrease in the standard deviation of INFLATION (approximately 1 percent point decrease in the standard deviation of annual CPI inflation). The results in columns (8)-(9) show that reputation has an insignificant effect on unemployment rates when control variables are added.

Panel B of Table 1 reports the 2SLS results where REPUTATION(1995-99) is instrumented by the turnover rates of CB governors (average during 1950-1989). The first-stage results show that the relevance condition of the instrument holds (i.e., a frequent change of $\mathrm{CB}$ governors significantly lowers reputation) although the F-statistics are not satisfactorily large. The exogeneity condition of the instrument (or exclusion restriction) is based on the assumption that governor turnover rates during 1950-89 affect inflation and unemployment only through the channel of reputation. This paper allows a time gap of more than 10-years between the instrument (1950-89 figure) and the dependent variable (2000-16 figures) so that channels other than reputational forces do not bias the result. The second-stage results show that reputation lowers the level and variance of inflation even when endogeneity issues are controlled (columns (1)-(6) of Panel B). The difference between the 2SLS estimators and the OLS estimators seems to be associated with the different sample countries (46 countries vs. 62 countries), different control variables, and estimation methods (2SLS vs OLS). Columns (7)-(9) indicate that reputation has insignificant effects on unemployment rates. 


\section{Robustness and Heterogeneity}

To show that cross-sectional results are not driven by outliers, a median regression is estimated and presented in Table A4 (Appendix). Estimation results, which measure responses of the conditional median of the dependent variable, are similar: high reputation leads to a low level and variance of subsequent inflation (columns (1)-(6)). The impact of reputation on unemployment rate is not statistically significant (columns (7)-(9)).

To examine the heterogeneous impact of reputation between high-income and low-income countries, samples are divided into two groups depending on per capita GDP in 1999. The impact of reputation is significant only in 31 low-income countries (Panel A). Insignificant coefficients of reputation in high-income countries seem to be associated with a small "between-country" variation in inflation rates: The mean and standard deviation of INFLATION(2000-16) among low-income countries are 0.056 and 0.042 , respectively, while those of high-income countries are only 0.020 and 0.0092 . 
Table 1. CB Reputation and Inflation-Unemployment Performance: Cross-section

Panel A: OLS

\begin{tabular}{|c|c|c|c|c|c|c|c|c|c|}
\hline \multirow[t]{2}{*}{ Dep Var= } & \multicolumn{3}{|c|}{$\begin{array}{c}\text { INFLATION } \\
(\pi /(100+\pi), 2000-16)\end{array}$} & \multicolumn{3}{|c|}{ S.D. of INFLATION (2000-16) } & \multicolumn{3}{|c|}{$\begin{array}{l}\text { UNEMPLOYMENT RATE } \\
(2000-16)\end{array}$} \\
\hline & (1) & (2) & (3) & (4) & (5) & (6) & (7) & (8) & (9) \\
\hline \multirow[t]{2}{*}{$\begin{array}{l}\text { REPUTATION } \\
\text { (1995-99) }\end{array}$} & $-0.0221^{* * *}$ & $-0.0209^{* *}$ & $-0.0192^{* *}$ & $-0.0118^{* * *}$ & $-0.0134^{* * *}$ & $-0.0105^{* *}$ & $-0.706^{* *}$ & -0.156 & 0.0122 \\
\hline & $(0.00569)$ & $(0.00913)$ & $(0.00954)$ & (0.00295) & (0.00396) & (0.00501) & (0.319) & $(0.486)$ & (0.510) \\
\hline \multirow{4}{*}{$\begin{array}{l}\text { REPUTATION } \\
\text { (1995-99) } \\
\text { XINFLATION } \\
\text { TARGETING } \\
\text { _1999 }\end{array}$} & & & & & & & & & \\
\hline & & $0.0145^{*}$ & $0.0163^{*}$ & & $0.0111^{* * *}$ & $0.0118^{* *}$ & & -0.0877 & 0.0675 \\
\hline & & & & & & & & & \\
\hline & & $(0.00835)$ & (0.00969) & & $(0.00387)$ & (0.00475) & & $(0.144)$ & (0.162) \\
\hline \multirow{2}{*}{$\begin{array}{l}\text { INFLATION } \\
\text { TARGETING } \\
\text {-1999 }\end{array}$} & & $-0.108^{*}$ & $-0.129^{*}$ & & $-0.0859^{* * *}$ & $-0.0947^{* * *}$ & & & \\
\hline & & (0.0600) & $(0.0697)$ & & (0.0278) & $(0.0348)$ & & & \\
\hline \multirow{2}{*}{$\begin{array}{l}\text { GROWTH } \\
(2000-16)\end{array}$} & & 0.00117 & 0.00180 & & 0.00173 & $0.00230^{*}$ & & & $-0.733^{* * *}$ \\
\hline & & (0.00158) & $(0.00133)$ & & $(0.00145)$ & $(0.00121)$ & & & (0.258) \\
\hline \multirow[t]{2}{*}{$\begin{array}{l}\text { OPENNESS } \\
(2000-16)\end{array}$} & & $-3.43 e-05$ & $1.95 e-05$ & & $1.14 \mathrm{e}-05$ & $2.98 \mathrm{e}-05$ & & $-0.0101^{*}$ & -0.00435 \\
\hline & & $(3.96 e-05)$ & $(3.94 e-05)$ & & $(2.70 \mathrm{e}-05)$ & $(2.61 \mathrm{e}-05)$ & & $(0.00518)$ & $(0.00553)$ \\
\hline \multirow[t]{2}{*}{$\begin{array}{l}\text { In(GDP per } \\
\text { capita, 1999) }\end{array}$} & & -0.00317 & 0.00103 & & 0.000325 & $0.00432^{*}$ & & -0.504 & $-1.450^{* * *}$ \\
\hline & & $(0.00413)$ & $(0.00331)$ & & $(0.00243)$ & (0.00233) & & $(0.473)$ & (0.448) \\
\hline \multirow[t]{2}{*}{ EAST ASIA } & & & $-0.0227^{* *}$ & & & $-0.00996^{*}$ & & & -1.268 \\
\hline & & & (0.0101) & & & $(0.00507)$ & & & (0.889) \\
\hline \multirow[t]{2}{*}{ LATIN } & & & 0.0310 & & & 0.00351 & & & -0.482 \\
\hline & & & $(0.0276)$ & & & $(0.0149)$ & & & (1.349) \\
\hline \multirow[t]{2}{*}{ NORDIC } & & & -0.000351 & & & -0.00437 & & & -1.167 \\
\hline & & & $(0.00691)$ & & & $(0.00449)$ & & & (0.981) \\
\hline \multirow[t]{2}{*}{ EURO } & & & -0.0122 & & & -0.00635 & & & 2.331* \\
\hline & & & $(0.00777)$ & & & $(0.00440)$ & & & (1.330) \\
\hline \multirow[t]{2}{*}{$\begin{array}{l}\text { INFLATION } \\
(1980-99)\end{array}$} & & & 0.0293 & & & 0.0559 & & & \\
\hline & & & $(0.0536)$ & & & (0.0382) & & & \\
\hline \multirow[t]{2}{*}{ Constant } & $0.184^{* * *}$ & $0.207^{* * *}$ & $0.151^{* *}$ & $0.103^{* * *}$ & $0.106^{* * *}$ & 0.0428 & $12.42^{* * *}$ & $14.36^{* * *}$ & $23.08^{* * *}$ \\
\hline & $(0.0401)$ & $(0.0352)$ & $(0.0607)$ & (0.0210) & $(0.0270)$ & $(0.0360)$ & (2.205) & (3.099) & (3.925) \\
\hline Observations & 62 & 62 & 62 & 62 & 62 & 62 & 62 & 62 & 62 \\
\hline R-squared & 0.427 & 0.501 & 0.641 & 0.323 & 0.448 & 0.575 & 0.034 & 0.084 & 0.311 \\
\hline
\end{tabular}

Robust standard errors in parentheses, ${ }^{* * *} \mathrm{p}<0.01, * * \mathrm{p}<0.05, * \mathrm{p}<0.1$ 
Central Bank Reputation and Inflation-Unemployment Performance: Empirical Evidence from an Executive Survey of 62 Countries

Panel B: 2 SLS

\begin{tabular}{|c|c|c|c|c|c|c|c|c|c|}
\hline \multicolumn{10}{|l|}{ 1st STAGE } \\
\hline \multirow[t]{2}{*}{ Dep Var= } & \multicolumn{6}{|c|}{ REPUTATION (1995-99) } & \multirow[b]{2}{*}{ (7) } & \multirow[b]{2}{*}{ (8) } & \multirow[b]{2}{*}{ (9) } \\
\hline & (1) & (2) & (3) & $(4)$ & (5) & (6) & & & \\
\hline \multirow{2}{*}{$\begin{array}{l}\text { GOVERNOR } \\
\text { TURNOVER } \\
\text { RATES } \\
\text { _1950_89 }\end{array}$} & $-1.710^{\text {** }}$ & $-1.595^{* *}$ & $-1.586^{\text {** }}$ & $-1.710^{* *}$ & $-1.595^{* *}$ & $-1.588^{* *}$ & $-1.710^{* *}$ & -0.955 & -0.934 \\
\hline & $(0.817)$ & $(0.778)$ & $(0.783)$ & $(0.817)$ & $(0.778)$ & $(0.783)$ & $(0.817)$ & $(0.683)$ & $(0.697)$ \\
\hline $\begin{array}{l}\text { Other } \\
\text { Variables }\end{array}$ & No & Yes & Yes & No & Yes & Yes & No & Yes & Yes \\
\hline F-stat & 4.37 & 3.96 & 2.65 & 4.37 & 3.96 & 2.65 & 4.37 & 7.35 & 5.93 \\
\hline \multicolumn{10}{|l|}{ 2nd STAGE } \\
\hline \multirow[t]{2}{*}{ Dep Var= } & \multicolumn{3}{|c|}{$\begin{array}{c}\text { INFLATION } \\
(\pi /(100+\pi), 2000-16)\end{array}$} & \multicolumn{3}{|c|}{ S.D. of INFLATION (2000-16) } & \multicolumn{2}{|c|}{$\begin{array}{r}\text { UNEMPLOYMENT } \\
(2000-16)\end{array}$} & RATE \\
\hline & (1) & (2) & (3) & (4) & (5) & (6) & (7) & (8) & (9) \\
\hline \multirow[t]{2}{*}{$\begin{array}{l}\text { REPUTATION } \\
(1995-99)\end{array}$} & $-0.0488^{* *}$ & $-0.0550^{* * *}$ & $-0.0526^{* * *}$ & $-0.0274^{*}$ & $-0.0322^{* *}$ & $-0.0291^{* *}$ & -1.987 & -2.249 & -2.070 \\
\hline & (0.0190) & $(0.0180)$ & (0.0172) & $(0.0145)$ & $(0.0131)$ & $(0.0129)$ & (1.623) & $(4.059)$ & (3.765) \\
\hline \multirow{2}{*}{$\begin{array}{l}\text { INFLATION } \\
\text { TARGETING } \\
\text { _1999 }\end{array}$} & & $-0.0300^{*}$ & $-0.0288^{*}$ & & $-0.0229^{* *}$ & $-0.0214^{* *}$ & & & \\
\hline & & $(0.0155)$ & (0.0152) & & $(0.0101)$ & (0.00952) & & & \\
\hline \multirow[t]{2}{*}{$\begin{array}{l}\text { GROWTH } \\
(2000-16)\end{array}$} & & & 0.00144 & & & 0.00182 & & & -0.810 \\
\hline & & & $(0.00243)$ & & & (0.00172) & & & $(0.557)$ \\
\hline \multirow[t]{2}{*}{$\begin{array}{l}\text { In(GDP per } \\
\text { capita, 1999) }\end{array}$} & & & & & & & & 0.150 & -0.661 \\
\hline & & & & & & & & (1.512) & $(1.925)$ \\
\hline \multirow[t]{2}{*}{ Constant } & $0.369^{* * *}$ & $0.420^{* 2 * *}$ & $0.399^{* * * *}$ & $0.210^{* *}$ & $0.248^{* * *}$ & $0.221^{* *}$ & $20.94^{*}$ & 21.36 & $30.17^{* * *}$ \\
\hline & $(0.131)$ & $(0.125)$ & $(0.120)$ & $(0.100)$ & $(0.0920)$ & $(0.0913)$ & (10.97) & $(14.61)$ & (7.959) \\
\hline Observations & 46 & 46 & 46 & 46 & 46 & 46 & 46 & 46 & 46 \\
\hline
\end{tabular}

Robust standard errors, ${ }^{* * *} \mathrm{p}<0.01, * * \mathrm{p}<0.05, * \mathrm{p}<0.1$, REPUTATION is instrumented by the GOVERNOR TURNOVER RATES. 


\section{2. (Dynamic) Panel Model}

While the previous analysis uses "between-country variation" in reputation to investigate if reputation explains heterogeneous inflation performances across countries, this section uses "within-country variation" in reputation to examine if the evolution of reputation explains changes in inflation performance over time within a country.

Data sets are constructed as follows. Three-year averaged data are used in order to average out year-specific shocks and to reflect sluggish responses of macro variables, as in Brito and Bystedt (2010) and Hwang (2017). Specifically, data are averaged over three-year non-overlapping periods between 1995 and 2016. As a result, the data set has 8 periods for 62 countries $(t=8, \quad \mathrm{~N}=62$; first period: average during 1995-97, second period: average during 1998-2000, and so on; see Table A1 in Appendix).

Following the literature standard, transformed values of inflation rates are used $(\pi /(100+\pi)=$ INFLATION). In the case of S.D. of INFLATION, the deviation of the transformed annual inflation rate from a three-year average is used.

The scatter plot in Figure 6 illustrates the three-year averaged data in a Phillips curve format. In developed countries, the level of reputation does not seem to affect inflation rates. In contrast, a high reputation appears to be associated with low inflation rates in developing countries. The Phillips curve (scatter plot) of developing countries suggests that CB reputation may be a factor that shifts the Phillips curve. 
Figure 6. Reputation-Augmented Phillips Curve

a. Developed Countries (21 countries)

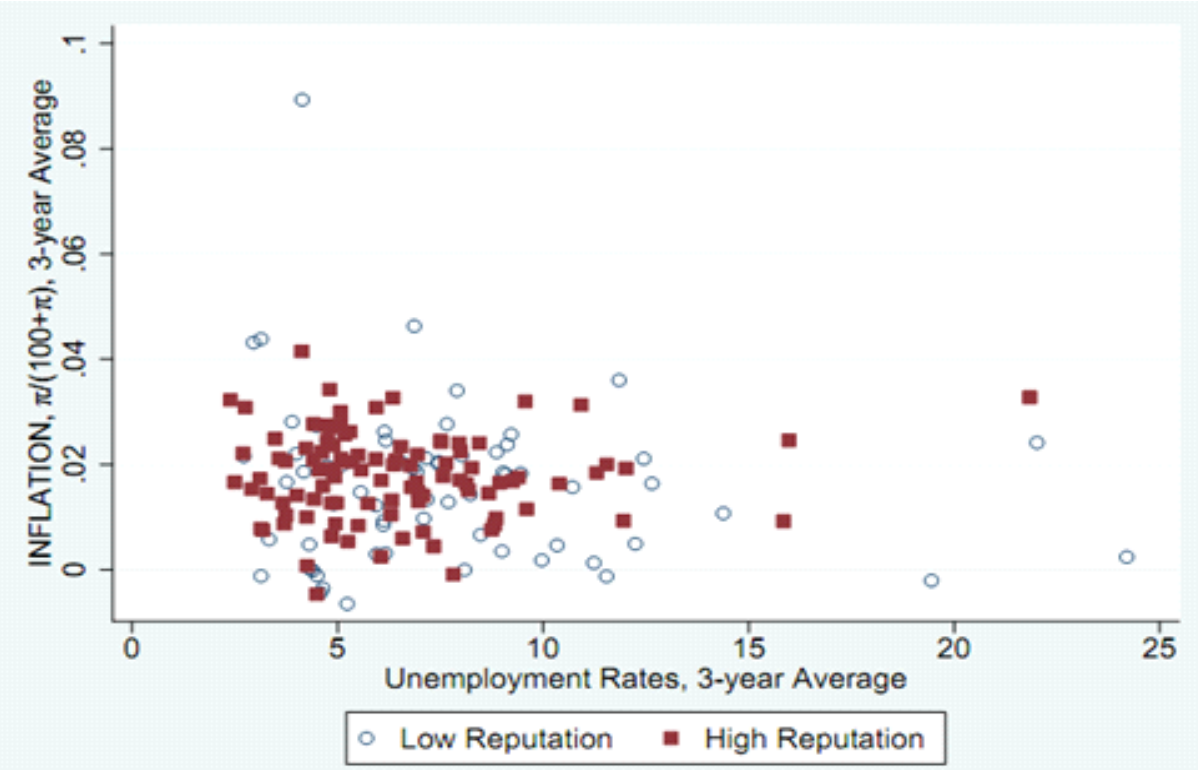

b. Developing Countries (41 countries)

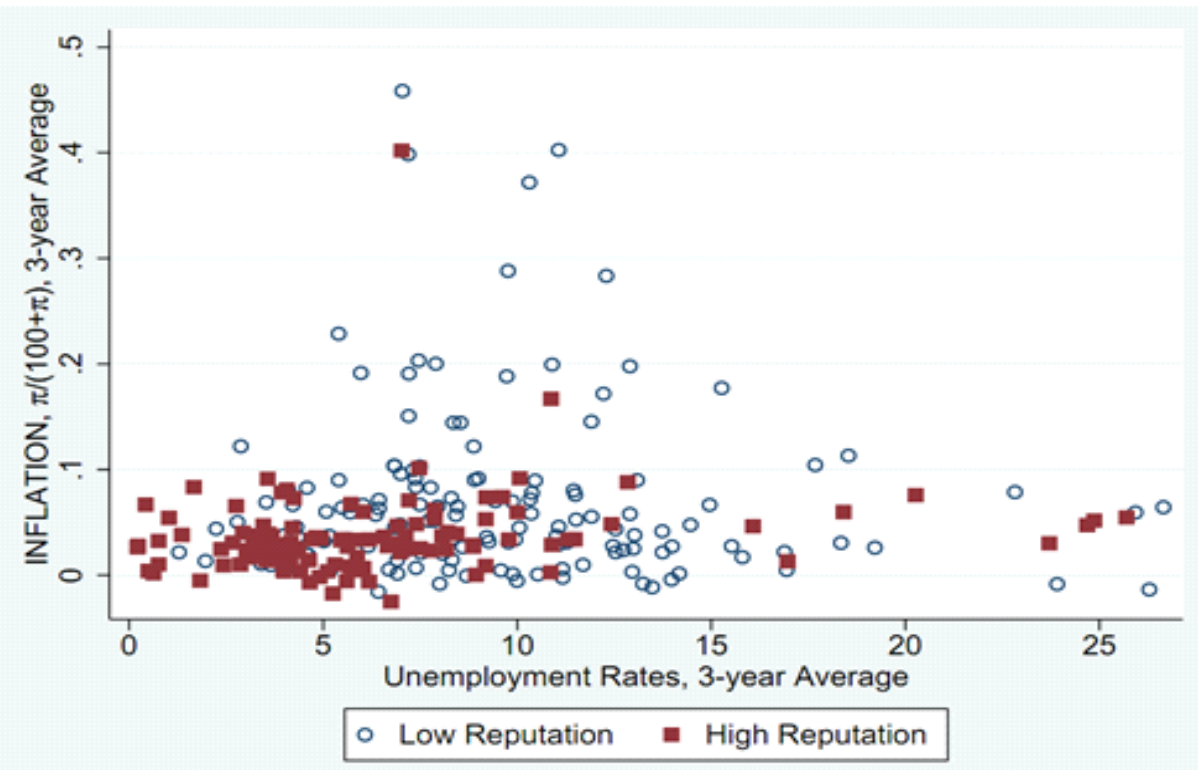

Notes: Observations are based on three-year averaged data ( $\mathrm{t}=8, \mathrm{~N}=62$ countries). A 'low reputation' means REPUTATION ${ }_{i t}<6.5$ (median), a 'high reputation' means REPUTATION $_{i t} \geq 6.5$. The $\mathrm{Y}$-axis is the transformed value of the inflation rate $(\pi)$. If $\pi=5$ percent, then INFLATION $=0.0476$ (5/105). The developed countries are 21 advanced economies defined in Cukierman et al (1992). The rest are classified as developing countries. 
For quantitative analysis, two panel-data models are employed: a fixed-effect panel model and Arellano-Bond's difference GMM model. While the fixed-effect panel model allows us to explore the effect of reputation on inflation when country-fixed effects and time-fixed effects are controlled for, it does not address a possible endogeneity problem. For example, the main explanatory variable, REPUTATION, may be an endogenous variable as reputation can be affected by, for instance, the business conditions of the country. To address the endogeneity problem in the "small $t$, large $N$ " panel data, Arellano-Bond's (1991) difference GMM model is also estimated. The difference GMM equation (3) can be obtained by taking the first difference of equation (2), the basic dynamic inflation equation.

$$
\begin{aligned}
\operatorname{INFLATION}_{i t}= & \alpha \operatorname{INFLATION}_{i t-1}+\beta X_{i, t}+u_{i t}, \\
& \text { where } X_{i t}=\text { contrlvariables, } u_{i t}=\mu_{i}+v_{i t}
\end{aligned}
$$

$$
\begin{aligned}
& \text { INFLATION }_{i t}-\text { INFLATION }_{i t-1} \\
& =\alpha\left(\text { INFLATION }_{i t-1}-\text { INFLATION }_{i t-2}\right)+\beta\left(X_{i t}-X_{i t-1}\right)+v_{i t}-v_{i t-1}
\end{aligned}
$$

Although country-fixed effect term $\mu_{i}$ (which may cause an inconsistency problem) is removed by taking the difference, equation (3) may also have endogeneity problem because both INFLATION ${ }_{i t-1}$ $-I N F L A T I O N_{i t-2}$ and $v_{i t}-v_{i t-1}$ are affected by $v_{i t-1}$. Arellano and Bond's (1991) difference GMM method is a type of instrumental variable (IV) approach which uses INFLATION $N_{i t-2}$ and $\triangle I N F L A T I O N_{i t-2}$ as instruments for INFLATION $N_{i t-1}-I_{N F L A T I O N_{i t-2}}$. The difference GMM estimator can be a consistent estimator if two moment conditions are met: (i) there is no second-order serial correlation in $v$ and (ii) instruments are not correlated with the error term $\left(v_{i t}-v_{i t-1}\right)$. 
Table 2. Reputation, Inflation, and Unemployment: (Dynamic) Panel Model

\begin{tabular}{|c|c|c|c|c|c|c|c|c|c|c|}
\hline \multirow{3}{*}{$\begin{array}{c}\text { Dep Var= } \\
\text { VARIABLES }\end{array}$} & \multicolumn{4}{|c|}{$I_{N F L A T I O N_{i t}}$} & \multicolumn{3}{|c|}{ S.D._INFLA TION } & \multicolumn{3}{|c|}{$\begin{array}{c}\text { UNEMPLOYMENT } \\
\text { RATE } \\
\end{array}$} \\
\hline & \multicolumn{3}{|c|}{ Fixed Effect Panel } & \multirow{2}{*}{$\begin{array}{c}\begin{array}{c}\text { AB Diff } \\
\text { GMM }\end{array} \\
(4)\end{array}$} & \multicolumn{2}{|c|}{$\begin{array}{l}\text { Fixed Effect } \\
\text { Panel }\end{array}$} & \multirow{2}{*}{$\begin{array}{c}\begin{array}{c}\text { AB Diff } \\
\text { GMM }\end{array} \\
(7)\end{array}$} & \multicolumn{2}{|c|}{$\begin{array}{l}\text { Fixed Effect } \\
\text { Panel }\end{array}$} & \multirow{2}{*}{$\begin{array}{l}\text { ABDiff } \\
\text { GMM } \\
(10)\end{array}$} \\
\hline & (1) & (2) & (3) & & (5) & (6) & & (8) & (9) & \\
\hline \multirow[t]{2}{*}{ REPUTA TION ${ }_{i t}$} & $-0.0125^{* * *}$ & $-0.0125^{* *}$ & $-0.00551^{*}$ & $-0.0110^{* * *}$ & $-0.00924^{* *}$ & -0.00267 & -0.00752 & $-0.918^{* * *}$ & $-0.715^{* * *}$ & $-0.528^{*}$ \\
\hline & $(0.00469)$ & $(0.00548)$ & $(0.00284)$ & $(0.00393)$ & $(0.00361)$ & $(0.00220)$ & $(0.00471)$ & $(0.341)$ & $\quad(0.246)$ & $(0.301)$ \\
\hline \multirow{2}{*}{$G D P_{-} G A P_{i t}$} & & 0.258 & 0.261 & $0.535^{* * *}$ & & -0.00651 & 0.231 & & $-65.41^{* * *}$ & $-81.94^{* * *}$ \\
\hline & & $(0.226)$ & $(0.206)$ & $(0.187)$ & & $(0.161)$ & $(0.228)$ & & (18.07) & (23.56) \\
\hline \multirow[t]{2}{*}{$\begin{array}{l}E F F E C T I V E \\
E X R A T E_{i t}\end{array}$} & & $-0.00131^{* * *}$ & $-0.000488^{* *}$ & -0.000204 & & -0.000269 & $-6.12 \mathrm{e}-05$ & & $-0.0340^{* *}$ & -0.0235 \\
\hline & & $(0.000366)$ & (0.000183) & (0.000196) & & $(0.000189)$ & $(0.000207)$ & & $(0.0160)$ & $(0.0154)$ \\
\hline \multirow[t]{2}{*}{$U N E M P R A T E_{i t}$} & & $-0.00261^{* * *}$ & -0.00128 & -0.00185 & & 0.000363 & 0.000326 & & & \\
\hline & & $(0.000816)$ & $(0.00123)$ & $(0.00118)$ & & $(0.000614)$ & $(0.000961)$ & & & \\
\hline \multirow[t]{2}{*}{$\begin{array}{l}\text { MONEY } \\
\text { GROWTH }\end{array}$} & & & $0.000582^{*}$ & 0.000333 & & $-6.24 e-06$ & $-9.63 e-05$ & & -0.0305 & $-0.0587^{*}$ \\
\hline & & & $(0.000327)$ & $(0.000327)$ & & $(0.000259)$ & $(0.000274)$ & & $(0.0209)$ & $(0.0302)$ \\
\hline \multirow[t]{2}{*}{$\begin{array}{l}\text { DEPENDENT } \\
\text { VARIABLE }\end{array}$} & & & $0.327^{* * *}$ & $0.409^{* * *}$ & & $0.259^{* *}$ & $0.309^{* *}$ & & $0.271^{* * *}$ & $0.544^{* * *}$ \\
\hline & & & (0.0604) & $(0.0711)$ & & $(0.120)$ & $(0.129)$ & & $(0.0721)$ & $(0.105)$ \\
\hline \multirow[t]{2}{*}{$\begin{array}{l}\text { INFLATION } \\
\text { TARGETING }_{i t}\end{array}$} & & & $-0.0192^{*}$ & -0.00218 & & -0.00925 & -0.00524 & & 0.589 & 1.149 \\
\hline & & & $(0.0104)$ & $(0.00532)$ & & $(0.00871)$ & $(0.00398)$ & & $(0.606)$ & $(0.709)$ \\
\hline \multirow[t]{2}{*}{$I_{N F L A T I O N}$} & & & & & & & & & 4.896 & $9.060^{*}$ \\
\hline & & & & & & & & & $(6.607)$ & $(5.026)$ \\
\hline \multirow[t]{2}{*}{ Constant } & $0.163^{* * *}$ & $0.274^{* * *}$ & $0.119^{* * *}$ & $0.114^{* * *}$ & $0.0865^{* * *}$ & 0.0539 & 0.0681 & $14.26^{* * *}$ & $12.99^{* * *}$ & $8.227^{* *}$ \\
\hline & $(0.0380)$ & $(0.0710)$ & (0.0354) & $(0.0369)$ & $(0.0283)$ & $(0.0346)$ & $(0.0446)$ & $(2.181)$ & (2.678) & (3.158) \\
\hline $\begin{array}{l}\text { Time Fixed } \\
\text { Effects }\end{array}$ & O & 0 & 0 & O & O & O & $\mathrm{O}$ & O & $\mathrm{O}$ & $\mathrm{O}$ \\
\hline $\begin{array}{l}\text { County Fixed } \\
\text { Effects }\end{array}$ & $\mathrm{O}$ & 0 & 0 & $\mathrm{O}^{\mathrm{a}}$ & 0 & O & $\mathrm{O}^{\mathrm{a}}$ & O & $\mathrm{O}$ & $\mathrm{O}^{\mathrm{a}}$ \\
\hline Observations $\left(\mathrm{N}^{*} \mathrm{t}\right)$ & 437 & 288 & 169 & 169 & 377 & 169 & 169 & 440 & 169 & 169 \\
\hline Number of Country(N) & 62 & 45 & 31 & 31 & 62 & 31 & 31 & 62 & 31 & 31 \\
\hline R-squared & 0.223 & 0.379 & 0.565 & - & 0.158 & 0.377 & - & 0.124 & 0.474 & - \\
\hline AR(1) Test ( $p$-value) & - & - & - & 0.014 & - & - & 0.041 & - & - & 0.039 \\
\hline AR(2) Test ( $p$-value) & - & - & - & 0.707 & - & - & 0.456 & - & - & 0.280 \\
\hline Sargan Test (p-value) & - & - & - & 0.212 & - & - & 0.000 & - & - & 0.000 \\
\hline Hansen J Test (p-value) & - & - & - & 1.000 & - & - & 1.000 & - & - & 1.000 \\
\hline
\end{tabular}

Notes: Heteroskedasticity and country-specific autocorrelation consistent t-statistics are in parentheses. Levels of significance: *** $1 \%, * * 5 \%, * 10 \%$. Columns (4), (7) and (10) report the first step estimators of Arellano-Bond difference GMM. (a) Since this paper estimates the first differenced equation, country-fixed effects cancel out in the difference GMM model. 
Control variables $X_{i t}$ are selected based on the literature on inflation dynamics. Money growth $(+)$, output gap $(+)$, past inflation levels $(+)$, real effective exchange rates (-), and a dummy variable for adopting IT (-) are used following the study by Deniz, Tekçe, and Yilmaz (2016). (The signs in parentheses indicate the expected relationship between the variable and inflation levels). These variables have well-established theoretical backgrounds. Since inflation is a monetary phenomenon (Friedman, 1963), money growth may affect inflation. The output gap may contribute to inflation according to the new Keynesian Phillips curve. (A simple form of the curve is as follows: $\pi_{t}=\beta E_{t}\left(\pi_{t+1}\right)+k\left(y-y^{p}\right)$, where $y-y^{p}=$ output gap or a proxy for real marginal cost.) The past level of inflation affects inflation through adaptive inflation expectations (Orphanides \& Williams, 2004). Real effective exchange rates may affect inflation through import prices of traded goods and their pass-through to non-traded goods (Kim, 2012). IT may stabilize inflation through increased credibility (Brito \& Bystedt, 2010).

The results in Table 2 show that a one-point increase in reputation leads to an approximately one-percent point decrease in inflation.4) All fixed-effect panel models in columns (1)-(3) include time fixed-effects terms as well as country fixed-effects terms. One can see that the effect of reputation on inflation is significant even after controlling for the effects of the GDP gap, effective exchange rates, unemployment rates, money growth rates, the lagged dependent variable ${ }^{5}$, and the indicator variable for adopting IT. The control variables have the right sign in their coefficients (Deniz et al. (2016) report similar panel regression results). Arellano and Bond's (1991) difference GMM estimators in column (4) confirm that reputation indeed affects inflation after

4) The effect of reputation is similar to that of Christelis et al. (2016), who report that a one standard deviation increase in trust in the ECB lowers expected inflation by 0.38 percent point, which is 22 percent of the sample mean of expected inflation rates. Considering the standard deviation of REPUTATION (1.2), the result in this paper implies that an increase in CB reputation of one standard deviation lowers inflation rates by approximately 1.2 percent point, which is 26 percent of the sample mean of INFLATION.

5) The coefficient of REPUTATION in column (3) is relatively small compared with those in columns (1)-(2) of Table 2. This seems to be caused by the addition of the lagged dependent variable capturing the persistent movement of inflation. 
controlling for the endogeneity problem. The results of the second-order serial correlation test $(\operatorname{AR}(2))$ and the Sargan test for overidentification restrictions show that two moment conditions are met.

The results in columns (5)-(7) in Table 2 indicate that reputation is associated with low variability of inflation, but the effect is not statistically significant when many control variables are added (column (6)) or endogeneity problems are controlled for (column (7)).

The results in columns (8)-(10) in Table 2 report the impact of reputation on unemployment rates. Contrary to the cross-sectional results, high CB reputation appears to be associated with low unemployment rates in a panel of countries, but this association turns out to be not robust (see the robustness check, column (9) of Table A8-A10 in the Appendix).

\section{Robustness Checks}

To check the robustness, (i) more control variables are added; (ii) a random effect model is estimated; and (iii) annual data instead of 3-year average data are used. Even when financial crisis and Eurozone dummy variables and the openness variable are controlled, CB reputation maintains a significant negative sign (columns (1)-(3) in Table A8). The impact of reputation on S.D._INFLATION and UNEMPLOYMENT RATE are negative as well, but the results are insignificant when GMM is employed (columns (6) and (9) in Table A8). When a random effect panel model is estimated, reputation has a significant effect on the level and variance of inflation (Table A9). Even when yearly data are used, the negative sign of reputation does not change and most of the results are statistically significant (Table A10). The use of annual data, however, raises a second-order serial correlation problem in the GMM model (column (4) in Table A10).

\section{H2. High Inflation $\Rightarrow$ Low Reputation}

To examine the two-way causal relationship between inflation and $\mathrm{CB}$ reputation, more regressions are estimated. The results in Table A7 (Appendix) 
show that high inflation lowers the level of $\mathrm{CB}$ reputation, supporting two-way causality. This result is consistent with the prediction of the Barro-Gordon model, which predicts that the private sector responds to the CB's inflation bias by lowering its confidence in $\mathrm{CB}$ policy.

\section{H4. Role of Reputation in a Low-Inflation Economy}

To test whether $\mathrm{CB}$ reputation remains an important determinant of economic outcomes in those countries that achieved the low-inflation steady-state, samples are limited to those countries whose 3-year-average inflation rates are never above 5 percent during 1995-2016 (See Table Al for details). The panel regression results for those 25 countries in Table A11 supports Faust and Svensson's (2001) claim: a one point increase in REPUTATION lowers INFLATION by 0.0091 in the FE model (column (2)) or by 0.0163 in the GMM model (column (4)), and the results are significant at the 5 percent level. Considering that the coefficients are similar to those of the baseline (-0.0125 and -0.011 ; columns (2) and (4) in Table 2), one may conclude that reputation plays a significant role in inflation performance even in the low-inflation environment.

\section{The Channel: Reputation and the (Anchoring of) Inflation Expectation}

While previous sections link reputation directly with inflation performance, this section considers the channel through which reputation affects inflation performance. Barro and Gordon (1983) and other studies suggest that CB reputation affects inflation performance through inflation expectations. This section examines if the data support that idea.

Long-run inflation expectation data are from the estimation results by Mehrotra and Yetman (2014), which uses multiple-horizon inflation forecast surveys collected by Consensus Economics. The scatter plot in Figure A5 in the Appendix shows that a high reputation (1995-1999 average) is associated with

low inflation expectations $\left(\pi^{*}\right)$ for the period of 2005-2012. Figure A6 shows 
Figure 7. Reputation and Anchoring of Inflation Expectation to Targets in IT Countries (Cross-section)

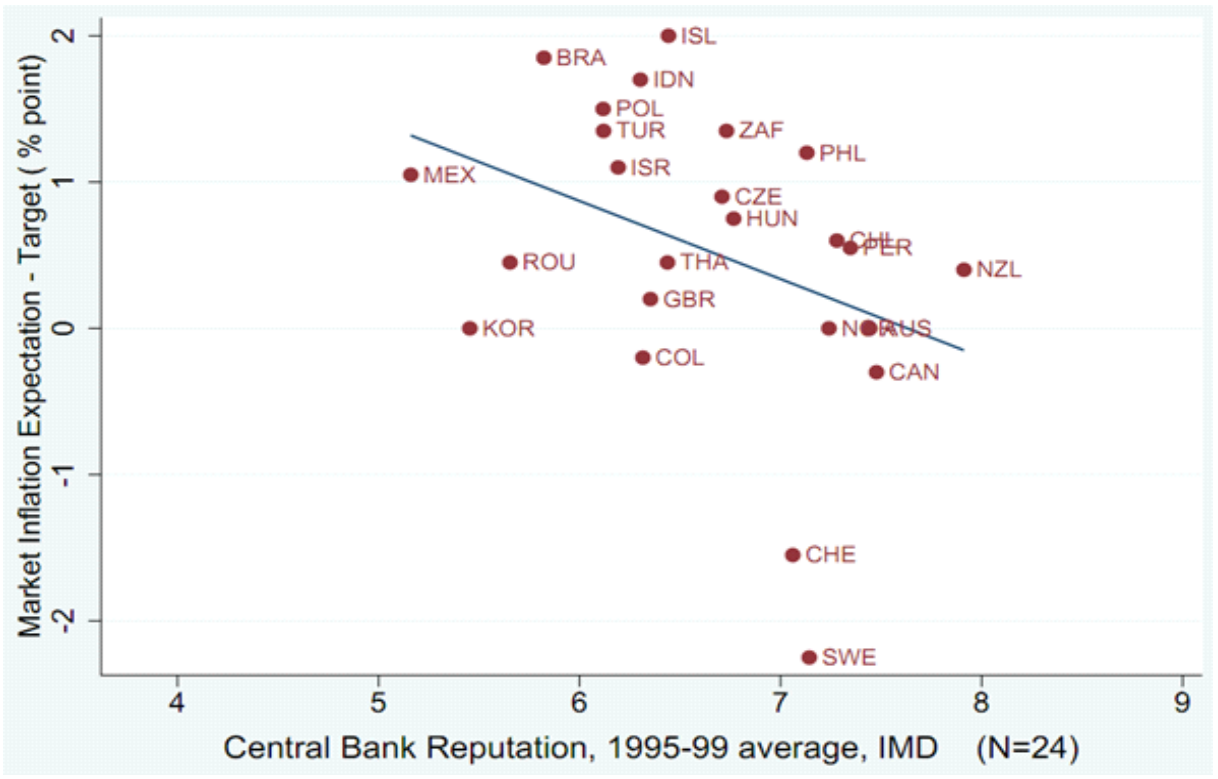

Notes: This plot shows that high reputation is associated with the tight anchoring of inflation expectations to the inflation targets. Market inflation expectations are averages of perceived inflation targets (annual, \%) from 199x to 2011 in Tas and Peker's study (2017). In their study, perceived inflation targets are extracted from the term structure of market interest rates. The exact year of the 199x varies depending on the IT-adoption year (see Table A1 for the IT adoption year). Targets are announced inflation targets (\%) during the same period.

that a high reputation is associated with low standard errors of the estimated inflation expectations (s.e. $\left(\pi^{*}\right)$ ).

Figure 7 examines whether high reputation leads to an anchoring of inflation expectations to the inflation targets using a different measure for inflation expectations. The Y-axis represents "Market $\pi^{e}$-target" from the 1990s to 2011, where Market $\pi^{e}$ is the perceived inflation target extracted from the term structure of long-term interest rates in Tas and Peker's (2017) study. The term is the announced inflation target of each country from 199x (IT adoption year) to 2011. The figure indicates that inflation expectations are well anchored to their targets in countries with high-reputation CBs.

Overall, the scatter plots in Figures A5-A6 and Figure 7 are consistent with the working of the expectation channel: a high reputation affects inflation 
performance through the channel of inflation expectations. However, important limitations in the analysis should be noted: (i) the analysis only applies a cross-sectional analysis (ii) the sample size is small (iii) control variables are not considered in the scatter plot analysis.

\section{Implications of Inflation Stabilizing Effects of Reputation in the Low-growth and Low-inflation Environment}

One may argue that achieving low inflation does not necessarily mean a better outcome considering the low growth and low inflation environment of the early- and mid-2010s. For example, the Bank of Japan has adopted quantitative easing (QE) to alleviate the deflationary pressure. However, the inflation -stabilizing effects of reputation are important for the following reasons. First, the inflation stabilizing effect of reputation is significant even when the output gap and unemployment rates are included as control variables. This implies that reputational forces may shift the inflation level down holding the output gap and unemployment rates constant. Similarly, when we set the dependent variable as unemployment rates instead of just controlling them, high reputation is estimated to lower unemployment rates whenever they are significant. Secondly, as Figure 7 illustrates, inflation expectations are above the inflation target in a large fraction of countries and hence lowering the expectations is still the primary objective of many CBs. The inflation records presented in Table Al show that a significant fraction of developing and transitional economies are still experiencing high inflation rates. For example, Argentina, India, Mongolia, Russia, Ukraine and Venezuela have experienced double-digit inflation rates in terms of three-year average rates since 2010. Only 25 out of 62 sample countries showed stable price trends, recording inflation rates of below 5 percent. Furthermore, even in these 25 low-inflation countries, reputation is estimated to play a significant role (See Table A11). Thirdly, the inflation-stabilizing effect of reputation is not driven by those countries that experience negative inflation rates. Table A6 in the Appendix shows that the effect of reputation is similar to the main results in Table 1 when eight countries that have experienced negative inflation rates are excluded from the sample. 


\section{Conclusion}

This paper measures CB reputation using the IMD's Executive Opinion Survey on CB policy and shows that a high reputation indeed lowers the level of inflation in a cross-section and panel of countries. Arellano-Bond's (1991) difference GMM model which uses 3-year averaged data during 1995-2016 confirms the causal relationship between reputation and the inflation level. The size of reputational effects is economically significant: a one-point increase in reputation (which has a scale of $0-10$, S.D. $\approx 1$ ) leads to a one to two percent point decrease in the level of annual inflation (\%) in non-IT countries. ${ }^{6}$ ) The effects of reputation on the volatility of inflation and unemployment rates are found to be less robust than those on inflation rates. Whenever the effects are significant, however, a high reputation is associated with a low volatility of inflation and a low level of unemployment rates.

This paper also finds that the inflation-stabilizing effect of reputation is larger in non-IT and developing countries than in IT and advanced countries. The sizeable impact of reputation in non-IT countries implies that reputation is especially important in countries without official commitment mechanisms such as IT, as Barro and Gordon (1983) claim. But at the same time, this paper finds that reputation still plays an important role in IT countries: high reputation is associated with a tight anchoring of inflation expectations to the inflation targets in IT countries. Another result to note is that CB reputation remains an important determinant of inflation in low-inflation economies, defined as those whose 3-year-average inflation rates were never above 5 percent during 1995-2016. With regard to the channel through which reputational forces work, this paper finds suggestive evidence that reputation affects inflation through inflation expectations.

This paper also finds that the relationship between reputation and inflation-unemployment is bi-directional: high inflation is estimated to lower $\mathrm{CB}$

6) The result varies depending on the estimation method. Arellano-Bond Difference GMM results suggest a 1.1 percent point decrease in the inflation rate, while the cross-section OLS estimation results suggest an approximately two percent point decrease in the inflation rate. 
reputation in the GMM model.

This paper contributes to the literature on monetary policy, reputation, and credibility in several ways.

i. We introduce a reputation measure which is based solely on private agents' perception of $\mathrm{CB}$ policy, allowing us to measure reputation directly.

ii. Using the direct measure, this paper provides the first empirical evidence that economic agents' trust in CB policy is truly key to inflation dynamics. In contrast, prior empirical studies on credibility derive the credibility index indirectly from inflation expectations or market interest rates and hence have limited power to test Barro-Gordon's (1983) hypothesis. Another closely related study is by Christelis et al. (2016); using survey data for Dutch households, they show that stronger trust in the ECB may lower inflation expectations. This paper confirms and extends Christelis et al.'s (2016) work, which examines heterogeneous inflation expectations in a cross-section of Dutch individuals, using inflation record data in a panel of 62 countries.

This paper offers several important policy implications by analyzing the determinants of reputation. Cross-sectional and (dynamic) panel regression results suggest that reputations are affected by inflation rates (-), unemployment rates (-), the occurrence of financial crises (-), CB governor turnover rates (-), communication as measured by the frequency of $\mathrm{CB}$ speeches $(+)$, and the introduction of IT (+). The negative effects of inflation, unemployment rates, and financial crisis on $\mathrm{CB}$ reputation suggest that, in order to enhance reputation, CBs should focus on achieving their primary objectives -price stability, employment sustainability, and financial stability. The positive association between the number of $\mathrm{CB}$ speeches and reputation indicates that communication with the public may contribute to improving reputation. The negative association of the turnover rate of $\mathrm{CB}$ governors with reputation suggests that actual $\mathrm{CB}$ independence may play a role in shaping public trust in CBs. The positive association between the indicator variable for adopting IT and reputation suggests that a monetary policy regime that ensures the credibility of monetary policy may raise reputation.

The limitations of this paper are as follows. First, the reputation measure 
from the IMD has several limitations. The survey only targets executives (or producers), not households or consumers. And since the sample size of respondents is small, the measure can be affected by changes in the respondents. (In 2016, a total of 5,400 executives participated in the IMD survey.) Second, the sample countries are limited to the 62 relatively open and developed countries where the IMD survey data are available. Thirdly and importantly, while this paper accepts that reputation is an endogenous variable (and hence uses predetermined values and employs 2SLS and GMM methods to alleviate the endogeneity problem), the full dynamics of reputation-building and inflation performance are not investigated. As the survey data from the IMD accumulate, researchers may verify the dynamics by using, for example, a Panel VAR method that fully takes the endogenous reputation-building process into consideration. 


\section{References}

Kim, K. H. (2012), "Pass-through Effects of Overseas Prices to Domestic Prices (in Korean)," Bank of Korea Discussion Paper Series, No. 2012-14.

Alesina, A., \& Summers, L. H. (1993), "Central Bank Independence and Macroeconomic Performance: Some Comparative Evidence," Journal of Money, Credit and Banking, Vol. 25(2), pp. 151-162.

Arellano, M., \& Bond, S. (1991), "Some Tests of Specification for Panel Data: Monte Carlo Evidence and an Application to Employment Equations," The Review of Economic Studies, Vol. 58(2), pp. 277-297.

Arifovic, J., \& Sargent, T. J. (2003), "Laboratory Experiments with an Expectational Phillips Curve," Evolution and Procedures in Central Banking, pp. 23-55.

Arnone, M., Laurens, B. J., Segalotto, J. F., \& Sommer, M. (2007), "Central Bank Autonomy: Lessons from Global Trends," IMF Working Paper, No. $07 / 88$.

Barro, R. J. (1986), "Reputation in a Model of Monetary Policy with Incomplete Information," Journal of Monetary Economics, Vol. 17(1), pp. 3-20.

Barro, R. J., \& Gordon, D. B. (1983), "Rules, Discretion and Reputation in a Model of Monetary Policy," Journal of Monetary Economics, Vol. 12(1), pp. 101-121.

Blinder, A. S. (2000), "Central-Bank Credibility: Why Do We Care? How Do We Build It?" The American Economic Review, Vol. 90(5), pp. 1421-1431.

Bomfim, A. N., \& Rudebusch, G. D. (2000), "Opportunistic and Deliberate Disinflation under Imperfect Credibility," Journal of Money, Credit and Banking, pp. 707-721. 
Bordo, M., \& Siklos, P. (2014), "Central Bank Credibility, Reputation and Inflation Targeting in Historical Perspective," National Bureau of Economic Research, No. w20693.

Bordo, M. D., \& Siklos, P. L. (2015), "Central Bank Credibility: An Historical and Quantitative Exploration," National Bureau of Economic Research, No. w20824.

Brito, R. D., \& Bystedt, B. (2010), "Inflation Targeting in Emerging Economies: Panel Evidence," Journal of Development Economics, Vol. 91(2), pp. 198-210.

Bursian, D., \& Fürth, S. (2015), “Trust me! I am a European Central Banker," Journal of Money, Credit and Banking, Vol. 47(8), pp. 1503-1530.

Cecchetti, S. G., \& Krause, S. (2002), "Central Bank Structure, Policy Efficiency, and Macroeconomic Performance: Exploring Empirical Relationships," Review-Federal Reserve Bank of Saint Louis, Vol. 84(4), pp. 47-60.

Christelis, D., Georgarakos, D., Jappelli, T., \& van Rooij, M. (2016), "Trust in the Central Bank and Inflation Expectations," CSEF Working Paper, No. 458.

Crowe, C., \& Meade, E. E. (2008), "Central Bank Independence and Transparency: Evolution and Effectiveness," European Journal of Political Economy, Vol. 24(4), pp. 763-777.

Cukierman, A., \& Gerlach, S. (2003), "The Inflation Bias Revisited: Theory and Some International Evidence," The Manchester School, Vol. 71(5), pp. 541-565.

Cukierman, A., \& Meltzer, A. H. (1986), "A Theory of Ambiguity, Credibility, and Inflation under Discretion and Asymmetric Information, Econometrica: Journal of the Econometric Society, Vol. 54(5), pp. 1099-1128. 
Cukierman, A., Web, S. B., \& Neyapti, B. (1992), "Measuring the Independence of Central Banks and Its Effect on Policy Outcomes," The World Bank Economic Review, Vol. 6(3), pp. 353-398.

Deniz, P., Tekce, M., \& Yilmaz, A. (2016), "Investigating the Determinants of Inflation: A Panel Data Analysis," International Journal of Financial Research, Vol. 7(2), pp. 233.

Duffy, J. M., \& Heinemann, F. (2016), “Central Bank Reputation, Cheap Talk and Transparency as Substitutes for Commitment: Experimental Evidence," SFB 649 Discussion Paper, No. 2016-053.

Ehrmann, M., Soudan, M., \& Stracca, L. (2012), “Explaining EU Citizens' Trust in the ECB in Normal and Crisis Times, ECB Working Paper, No. 1501.

Faust, J., \& Svensson, L. E. (2001), "Transparency and Credibility: Monetary Policy with Unobservable Goals," International Economic Review, Vol. 42(2), pp. 369-397.

Fischer, J. A., \& Hahn, V. (2008), "Determinants of Trust in the European Central Bank," SSE/EFI Working Paper Series in Economics and Finance, No. 695.

Goldberg, L. S., \& Klein, M. W. (2010), "Evolving Perceptions of Central Bank Credibility: The European Central Bank Experience," In NBER International Seminar on Macroeconomics 2010, University of Chicago Press, pp. 153-182.

Gonçalves, C. E. S., \& Carvalho, A. (2009), "Inflation Targeting Matters: Evidence from OECD Economies' Sacrifice Ratios," Journal of Money, Credit and Banking, Vol. 41(1), pp. 233-243.

Hwang, I. D. (2017), "Which Type of Trust Matters?: Interpersonal vs. Institutional vs. Political Trust," Bank of Korea WP 2017-15.

Kril, Z., Leiser, D., \& Spivak, A. (2016), "What Determines the Credibility 
of the Central Bank of Israel in the Public Eye?" International Journal of Central Banking.

Levieuge, G., Lucotte, Y., \& Ringuedé, S. (2015), “Central Bank Credibility and the Expectations Channel: Evidence Based on a New Credibility Index,” NBP Working Papers, No. 209.

Lustenberger, T., \& Rossi, E. (2018), "Does Central Bank Transparency and Communication Affect Financial and Macroeconomic Forecasts?" Swiss National Bank.

Mariscal, I. B. F., Wong, W., \& Howells, P. (2011), "Measuring the Policymaker's Credibility: The Bank of England in 'nice' and 'not-so-nice' Times," No. 20111110.

Mehrotra, A., \& Yetman, J. (2014), "Decaying Expectations: What Inflation Forecasts Tell Us about the Anchoring of Inflation Expectations," BIS Working Papers, No. 464.

Milton Friedman (1963), "Inflation Causes and Consequences," Asian Publishing House.

Orphanides, A., \& Williams, J. (2004), "Imperfect Knowledge, Inflation Expectations, and Monetary Policy," In the Inflation-targeting Debate, University of Chicago Press, pp. 201-246.

Tas, B. K. O., \& Peker, M. C. (2017), "Inflation Target Credibility: Do the Financial Markets Find the Targets Believable?" Oxford Bulletin of Economics and Statistics, Vol. 79(6), pp. 1125-1147.

Walsh, C. E. (1995), "Optimal Contracts for Central Bankers," The American Economic Review, pp. 150-167.

Wälti, S. (2012), "Trust No More? The Impact of the Crisis on Citizens' Trust in Central Banks," Journal of International Money and Finance, Vol. 31(3), pp. 593-605. 


\section{Appendix}

Table A1. List of 62 Countries and Consumer Prices Inflation ${ }^{1)}$ (Annual, \%)

\begin{tabular}{|c|c|c|c|c|c|c|c|c|c|c|c|}
\hline & $\begin{array}{c}\text { IT } \\
\text { adoption } \\
\text { year }^{2}\end{array}$ & $\begin{array}{l}\text { Developed } \\
\text { countries }^{3)}\end{array}$ & $\begin{array}{c}t=1 \\
(1995 \\
-97)\end{array}$ & $\begin{array}{c}t=2 \\
(1998 \\
-00)\end{array}$ & $\begin{array}{l}\mathrm{t}=3 \\
(2001 \\
-03)\end{array}$ & $\begin{array}{l}t=4 \\
(2004 \\
-06)\end{array}$ & $\begin{array}{l}\mathrm{t}=5 \\
(2007 \\
-09)\end{array}$ & $\begin{array}{l}\mathrm{t}=6 \\
(2010 \\
-12)\end{array}$ & $\begin{array}{l}\mathrm{t}=7 \\
(2013 \\
-15)\end{array}$ & $\begin{array}{c}\mathrm{t}=8 \\
(2016)\end{array}$ & $\begin{array}{c}\pi_{t}<5 \% \\
\forall t=1, \ldots, 8\end{array}$ \\
\hline Argentina & & 0 & 1.4 & -0.4 & 12.7 & 8.3 & 7.9 & 10.1 & 10.6 & & \\
\hline Australia & 1993 & 1 & 2.5 & 2.3 & 3.4 & 2.9 & 2.8 & 2.6 & 2.1 & 1.3 & Yes \\
\hline Austria & & 1 & 1.8 & 1.3 & 1.9 & 1.9 & 2.0 & 2.5 & 1.5 & 0.9 & Yes \\
\hline Belgium & & 1 & 1.7 & 1.5 & 1.9 & 2.2 & 2.1 & 2.9 & 0.7 & 2.0 & Yes \\
\hline Brazil & 1999 & 0 & 29.6 & 5.0 & 10.0 & 5.9 & 4.7 & 5.7 & 7.2 & 8.7 & \\
\hline Bulgaria & & 0 & 414.0 & 10.5 & 5.1 & 6.2 & 7.8 & 3.2 & -0.2 & -0.8 & \\
\hline Canada & 1991 & 1 & 1.8 & 1.8 & 2.5 & 2.0 & 1.6 & 2.1 & 1.3 & 1.4 & Yes \\
\hline Chile & 1991 & 0 & 7.2 & 4.1 & 3.0 & 2.5 & 4.4 & 2.6 & 3.5 & 3.8 & \\
\hline $\begin{array}{l}\text { China } \\
\text { Mainland }\end{array}$ & & 0 & 9.3 & -0.7 & 0.4 & 2.4 & 3.3 & 3.8 & 2.0 & 2.0 & \\
\hline Colombia & 1999 & 0 & 20.1 & 12.9 & 7.1 & 5.1 & 5.6 & 3.0 & 3.3 & 7.5 & \\
\hline Croatia & & 0 & 4.2 & 5.0 & 2.4 & 2.9 & 3.8 & 2.2 & 0.5 & -1.1 & \\
\hline $\begin{array}{l}\text { Czech } \\
\text { Republic }\end{array}$ & & 0 & 8.8 & 5.6 & 2.2 & 2.4 & 3.4 & 2.2 & 0.7 & 0.6 & \\
\hline Denmark & & 1 & 2.1 & 2.4 & 2.3 & 1.6 & 2.1 & 2.5 & 0.6 & 0.2 & Yes \\
\hline Estonia & & 0 & 20.8 & 5.2 & 3.6 & 3.9 & 5.6 & 4.0 & 0.7 & 0.1 & \\
\hline Finland & & 1 & 0.9 & 2.0 & 1.7 & 0.9 & 2.2 & 2.5 & 0.8 & 0.4 & Yes \\
\hline France & & 1 & 1.7 & 0.9 & 1.9 & 1.9 & 1.5 & 1.9 & 0.5 & 0.2 & Yes \\
\hline Germany & & 1 & 1.7 & 1.0 & 1.5 & 1.6 & 1.7 & 1.7 & 0.9 & 0.5 & Yes \\
\hline Greece & & 0 & 7.6 & 3.5 & 3.5 & 3.2 & 2.8 & 3.2 & -1.3 & -0.8 & \\
\hline $\begin{array}{l}\text { Hong Kong } \\
\text { SAR }\end{array}$ & & 0 & 7.0 & -1.6 & -2.4 & 0.9 & 2.3 & 3.9 & 3.9 & 2.4 & \\
\hline Hungary & 2001 & 0 & 23.3 & 11.3 & 6.4 & 4.7 & 6.1 & 4.8 & 0.5 & 0.4 & \\
\hline Iceland & 2001 & 1 & 1.9 & 3.4 & 4.5 & 4.6 & 9.9 & 4.9 & 2.5 & 1.7 & \\
\hline India & & 0 & 8.8 & 7.3 & 4.0 & 4.7 & 8.5 & 10.1 & 7.5 & 4.9 & \\
\hline Indonesia & & 0 & 7.9 & 27.5 & 10.0 & 9.9 & 7.0 & 4.9 & 6.4 & 3.5 & \\
\hline Ireland & & 1 & 1.9 & 3.2 & 4.3 & 2.9 & 1.5 & 1.1 & 0.1 & 0.0 & Yes \\
\hline Israel & 1992 & 0 & 10.1 & 3.9 & 2.5 & 1.0 & 2.8 & 2.6 & 0.5 & -0.5 & \\
\hline Italy & & 1 & 3.8 & 2.0 & 2.6 & 2.1 & 2.0 & 2.4 & 0.5 & -0.1 & Yes \\
\hline Japan & & 1 & 0.6 & -0.1 & -0.6 & 0.0 & 0.0 & -0.3 & 1.3 & -0.1 & Yes \\
\hline Jordan & & 0 & 4.0 & 1.5 & 1.7 & 4.4 & 6.5 & 4.6 & 2.3 & -0.8 & \\
\hline Kazakhstan & & 0 & 77.6 & 9.5 & 6.9 & 7.7 & 11.7 & 6.9 & 6.4 & & \\
\hline Korea Rep. & 1998 & 0 & 4.6 & 3.5 & 3.4 & 2.9 & 3.3 & 3.1 & 1.1 & 1.0 & Yes \\
\hline Latvia & & 0 & 17.0 & 3.2 & 2.5 & 6.5 & 9.7 & 1.8 & 0.3 & 0.1 & \\
\hline Lithuania & & 0 & 24.4 & 2.3 & 0.2 & 2.5 & 7.0 & 2.8 & 0.1 & 0.9 & \\
\hline Luxembourg & & 1 & 1.6 & 1.7 & 2.3 & 2.5 & 2.0 & 2.8 & 0.9 & 0.3 & Yes \\
\hline Malaysia & & 0 & 3.2 & 3.2 & 1.4 & 2.7 & 2.7 & 2.2 & 2.5 & 2.1 & Yes \\
\hline
\end{tabular}




\begin{tabular}{|c|c|c|c|c|c|c|c|c|c|c|c|}
\hline & \multicolumn{10}{|c|}{$\begin{array}{c}\text { Central Bank Reputation and Inflation-Unemployment Performance: } \\
\text { Empirical Evidence from an Executive Survey of } 62 \text { Countries }\end{array}$} & \multirow[b]{2}{*}{$\begin{array}{c}\pi_{t}<5 \% \\
\forall t=1, . ., 8\end{array}$} \\
\hline & $\begin{array}{c}\text { IT } \\
\text { adoption }_{\text {year }^{2)}}\end{array}$ & $\begin{array}{l}\text { Developed } \\
\text { countries }^{3)}\end{array}$ & $\begin{array}{c}t=1 \\
(1995 \\
-97)\end{array}$ & $\begin{array}{c}\mathrm{t}=2 \\
(1998 \\
-00)\end{array}$ & $\begin{array}{c}t=3 \\
(2001 \\
-03)\end{array}$ & $\begin{array}{c}t=4 \\
(2004 \\
-06)\end{array}$ & $\begin{array}{c}t=5 \\
(2007 \\
-09)\end{array}$ & $\begin{array}{c}t=6 \\
(2010 \\
-12)\end{array}$ & $\begin{array}{c}t=7 \\
(2013 \\
-15)\end{array}$ & $\begin{array}{c}t=8 \\
(2016)\end{array}$ & \\
\hline Mexico & 1999 & 0 & 30.0 & 14.0 & 5.3 & 4.1 & 4.8 & 3.9 & 3.5 & 2.8 & \\
\hline Mongolia & & 0 & 27.8 & 9.5 & 4.1 & 8.7 & 13.5 & 11.5 & 9.1 & 0.6 & \\
\hline Netherlands & & 1 & 2.0 & 2.2 & 3.2 & 1.4 & 1.8 & 2.0 & 1.4 & 0.3 & Yes \\
\hline $\begin{array}{l}\text { New } \\
\text { Zealand }\end{array}$ & 1990 & 1 & 2.4 & 1.5 & 2.1 & 2.9 & 2.8 & 2.5 & 0.8 & 0.5 & Yes \\
\hline Norway & 2001 & 1 & 2.1 & 2.6 & 2.3 & 1.4 & 2.2 & 1.5 & 2.1 & 3.6 & Yes \\
\hline Peru & 2002 & 0 & 10.4 & 4.8 & 1.5 & 2.4 & 3.5 & 2.9 & 3.2 & 3.6 & \\
\hline Philippines & 2002 & 0 & 6.6 & 6.4 & 3.5 & 5.6 & 5.1 & 3.9 & 2.8 & 1.8 & \\
\hline Poland & 1998 & 0 & 21.0 & 9.7 & 2.7 & 2.3 & 3.5 & 3.5 & 0.0 & -0.6 & \\
\hline Portugal & & 0 & 3.1 & 2.6 & 3.7 & 2.5 & 1.5 & 2.6 & 0.2 & 0.6 & Yes \\
\hline Qatar & & 0 & 4.2 & 2.3 & 1.3 & 9.1 & 8.0 & 0.5 & 2.7 & 2.9 & \\
\hline Romania & & 0 & 75.3 & 50.2 & 24.1 & 9.2 & 6.1 & 5.1 & 1.5 & -1.5 & \\
\hline Russia & & 0 & 86.7 & 44.7 & 17.0 & 11.1 & 11.6 & 6.8 & 10.0 & 7.1 & \\
\hline Saudi Arabia & & 0 & 2.0 & -0.9 & -0.1 & 1.1 & 6.4 & 4.7 & 2.8 & 3.5 & \\
\hline Singapore & & 0 & 1.7 & 0.4 & 0.4 & 1.0 & 3.1 & 4.2 & 1.0 & -0.5 & Yes \\
\hline $\begin{array}{l}\text { Slovak } \\
\text { Republic }\end{array}$ & & 0 & 7.3 & 9.8 & 6.4 & 4.9 & 3.0 & 2.8 & 0.3 & -0.5 & \\
\hline Slovenia & & 0 & 10.5 & 7.6 & 7.2 & 2.8 & 3.4 & 2.1 & 0.5 & -0.1 & \\
\hline South Africa & 2000 & 0 & 8.2 & 5.8 & 6.9 & 3.1 & 8.6 & 5.0 & 5.5 & 6.3 & \\
\hline Spain & & 1 & 3.4 & 2.5 & 3.2 & 3.3 & 2.2 & 2.5 & 0.3 & -0.2 & Yes \\
\hline Sweden & 1993 & 1 & 1.2 & 0.5 & 2.2 & 0.7 & 1.7 & 1.7 & -0.1 & 1.0 & Yes \\
\hline Switzerland & & 1 & 1.0 & 0.8 & 0.8 & 1.0 & 0.9 & 0.1 & -0.5 & -0.4 & Yes \\
\hline Taiwan & & 0 & 2.5 & 1.0 & -0.2 & 1.5 & 1.5 & 1.4 & 0.6 & 1.4 & Yes \\
\hline Thailand & 2000 & 0 & 5.7 & 3.3 & 1.4 & 4.0 & 2.3 & 3.4 & 1.1 & 0.2 & \\
\hline Turkey & 2006 & 0 & 84.7 & 68.1 & 41.6 & 10.1 & 8.5 & 8.0 & 8.0 & 7.8 & \\
\hline UAE & & 0 & 3.4 & 1.8 & 2.9 & 6.8 & 8.3 & 0.8 & 2.5 & 1.8 & \\
\hline Ukraine & & 0 & 157.7 & 20.5 & 6.0 & 10.6 & 18.0 & 6.0 & 20.2 & 13.9 & \\
\hline $\begin{array}{l}\text { United } \\
\text { Kingdom }\end{array}$ & 1992 & 1 & 2.3 & 1.2 & 1.3 & 1.9 & 2.7 & 3.5 & 1.4 & 0.6 & Yes \\
\hline USA & & 1 & 2.7 & 2.4 & 2.2 & 3.1 & 2.1 & 2.3 & 1.1 & 1.3 & Yes \\
\hline Venezuela & & 0 & 69.9 & 25.2 & 22.0 & 17.1 & 25.7 & 25.1 & 70.8 & & \\
\hline
\end{tabular}

Notes: 1) Source: World Development Indicators

2) Source: Bank of Korea (2012), "Monetary Policy in Korea"

3) Countries that are classified as industrial countries in Cukierman et al. (1992) 
Table A2. Descriptions and Sources of Data

\begin{tabular}{|c|c|c|c|c|c|c|c|}
\hline & $\begin{array}{c}\text { Variable } \\
\text { (averaged year) }\end{array}$ & Obs & Mean & $\begin{array}{l}\text { Std. } \\
\text { Dev. }\end{array}$ & Min & Max & Description, Source \\
\hline \multirow{11}{*}{ 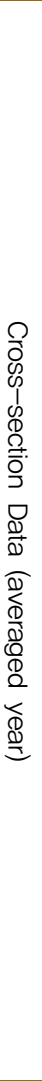 } & $\begin{array}{l}\text { INFLATION } \\
(2000-16)\end{array}$ & 62 & 0.0377 & 0.0352 & 0.000040 & 0.220 & $\begin{array}{l}\text { Transformed inflation }=\pi /(100+\pi) \\
\pi \text { is consumer prices inflation (annual \%) } \\
\text { World Development Indicators (WDI) }\end{array}$ \\
\hline & $\begin{array}{l}\text { S.D. of } \\
\text { INFLATION } \\
\text { (2000-16) }\end{array}$ & 62 & 0.0247 & 0.0217 & 0.0066 & 0.106 & $\begin{array}{l}\text { Standard deviation of transformed } \\
\text { inflation, WDI } \\
\text { (Sample S.D. from the 16-year average) }\end{array}$ \\
\hline & $\begin{array}{l}\text { REPUTATION } \\
\text { (1995-99) }\end{array}$ & 62 & 6.632 & 1.042 & 3.715 & 8.582 & $\begin{array}{l}\text { IMD World Competitiveness Yearbook. } \\
\text { Survey on "Central Bank Policy" (0-10 } \\
\text { scale). Average during } 1995-1999 \text { ( } 47 \\
\text { countries). For countries where the } \\
\text { survey on central bank policy began in } \\
2000 \text { or after (15 countries), the average } \\
\text { figures for the first year of the survey } \\
\text { through } 2016 \text { are used. }\end{array}$ \\
\hline & $\begin{array}{l}\text { INFLATION } \\
\text { TARGETING_1999 }\end{array}$ & 62 & 0.210 & 0.410 & 0 & 1 & $\begin{array}{l}\text { An indicator variable for adopting IT as of } 1999 \\
\text { (See Table A1 for the IT adoption year) }\end{array}$ \\
\hline & $\begin{array}{l}\text { GROWTH } \\
(2000-16)\end{array}$ & 62 & 3.437 & 2.032 & 0.169 & 10.243 & Real GDP growth rate (annual, \%), WDI \\
\hline & $\begin{array}{l}\text { OPENNESS } \\
(2000-16)\end{array}$ & 62 & 96.879 & 70.154 & 25.687 & 381.269 & (Export+Import)/GDP, \%, WDI \\
\hline & $\begin{array}{l}\text { In(GDP per } \\
\text { capita, 1999) }\end{array}$ & 62 & 8.929 & 1.314 & 6.098 & 10.851 & WDI \\
\hline & $\begin{array}{l}\text { INFLATION } \\
(1980-99)\end{array}$ & 62 & 0.148 & 0.149 & 0.006 & 0.594 & WDI \\
\hline & $\begin{array}{l}\text { COMMUNICATION } \\
(1998-2014)\end{array}$ & 57 & 0.674 & 1.072 & 0.00 & 6.79 & $\begin{array}{l}\text { Average number of } \mathrm{CB} \text { speeches in a } \\
\text { month collected by the BIS, Source: } \\
\text { Lustenberger and Rossi(2017) }\end{array}$ \\
\hline & $\begin{array}{l}\text { TRANSPARENCY } \\
-1998\end{array}$ & 53 & 0.528 & 0.177 & 0.10 & 0.90 & $\begin{array}{l}\text { Based on survey responses targeting } \\
\text { central bankers, } \\
\text { Source: Fry et al. (2000) in Crowe and } \\
\text { Meade (2008) }\end{array}$ \\
\hline & $\begin{array}{l}\text { UNEMPLOYMENT } \\
\text { RATE(2000-16) }\end{array}$ & 62 & 7.735 & 4.012 & 1.259 & 24.754 & WDI (ILO estimate) \\
\hline \multirow{9}{*}{ 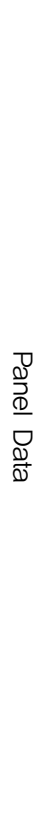 } & $I_{N F L A T I O N}$ & 501 & 0.0456 & 0.0686 & -0.0250 & 0.6151 & Transformed inflation (3-year average, \%) \\
\hline & $\begin{array}{l}\text { S.D. } \\
\text { INFET } T I O N_{i t}\end{array}$ & 440 & 0.0197 & 0.0351 & 0.0002 & 0.3266 & $\begin{array}{l}\text { Standard deviation of transformed } \\
\text { inflation, WDI } \\
\text { (Deviation of annual inflation from the } \\
\text { 3-year average) }\end{array}$ \\
\hline & REPUTA TION & 440 & 6.3022 & 1.2210 & 0.5600 & 8.6720 & IMD (see above description) \\
\hline & $G D P_{-} G A P_{i t}$ & 440 & 0.00044 & 0.01163 & -0.05090 & 0.05223 & $\begin{array}{l}\text { GDP (constant, WDI) / Potential GDP, } \\
\text { Author estimated potential GDP using HP } \\
\text { filtering (lamda=6.25) }\end{array}$ \\
\hline & UNEMP RATE & 504 & 7.807 & 4.533 & 0.220 & 26.647 & $\begin{array}{l}\text { Unemployment, total (\% of total labor } \\
\text { force), WDI }\end{array}$ \\
\hline & $\begin{array}{l}\text { MONEY } \\
\text { GROWTH }\end{array}$ & 356 & 18.187 & 56.603 & -10.431 & 1040.2 & Broad money growth (annual \%), WDI \\
\hline & $\begin{array}{l}\text { EFFECTIVE } \\
\text { EX RATE }\end{array}$ & 366 & 95.48 & 13.38 & 46.80 & 143.63 & $\begin{array}{l}\text { Real effective exchange rate index } \\
(2010 \stackrel{100) \text {, WDI }}{ }\end{array}$ \\
\hline & $\begin{array}{l}\text { INFLA TION } \\
\text { TARGETING }_{i t}\end{array}$ & 504 & 0.308 & 0.462 & 0 & 1 & $\begin{array}{l}\text { Dummy variable for adopting IT for the period } \\
\text { (see Table A1 for details) }\end{array}$ \\
\hline & $\begin{array}{l}\text { FINANCIAL } \\
\text { CRISIS } \\
\text { DUMMIES }\end{array}$ & - & - & - & 0 & 1 & $\begin{array}{l}16 \text { dummy variables for } 16 \text { countries. } \\
\text { Each dummy variable has a value of one } \\
\text { if the country experiences an economic } \\
\text { crisis during the period. } \\
\text { Based on the "List of economic crises" in } \\
\text { wikipedia.org }\end{array}$ \\
\hline
\end{tabular}



Empirical Evidence from an Executive Survey of 62 Countries

Table A3. Is the Reputation Measure from IMD a Reliable Proxy for Central Bank Reputation?

Reputation, Inflation, Unemployment, Communication, and Central Bank Independence

\begin{tabular}{|c|c|c|c|c|c|}
\hline \multirow{2}{*}{ VARIABLES } & \multicolumn{2}{|c|}{ Dependent Variable } & \multicolumn{3}{|c|}{ REPUTATION (average 2000-16) } \\
\hline & (1) & (2) & (3) & (4) & (5) \\
\hline INFLATION_1980_99 & $\begin{array}{r}-3.457^{* * *} \\
(0.912)\end{array}$ & $\begin{array}{r}-3.163^{* * *} \\
(0.960)\end{array}$ & $\begin{array}{r}-2.601^{* *} \\
(1.051)\end{array}$ & $\begin{array}{l}-0.670 \\
(1.073)\end{array}$ & $\begin{array}{l}-0.999 \\
(1.047)\end{array}$ \\
\hline UNEMP_1995_99 & & $\begin{array}{l}-0.0372 \\
(0.0248)\end{array}$ & $\begin{array}{r}-0.0458 * \\
(0.0261)\end{array}$ & $\begin{array}{r}-0.0475^{*} \\
(0.0265)\end{array}$ & $\begin{array}{l}-0.0163 \\
(0.0182)\end{array}$ \\
\hline INFLATION TARGETING (as of 1999) & & $\begin{array}{r}0.583^{* *} \\
(0.225)\end{array}$ & $\begin{array}{r}0.512^{* *} \\
(0.228)\end{array}$ & $\begin{array}{r}0.621^{* *} \\
(0.251)\end{array}$ & $\begin{array}{l}0.612^{*} \\
(0.328)\end{array}$ \\
\hline In(GDP per capita, as of 1999) & & & $\begin{array}{l}-0.0101 \\
(0.0766)\end{array}$ & $\begin{array}{l}-0.0633 \\
(0.0660)\end{array}$ & $\begin{array}{l}-0.132 \\
(0.106)\end{array}$ \\
\hline COMMUNICATION_1998_2014 & & & $\begin{array}{r}0.110^{*} \\
(0.0585)\end{array}$ & $\begin{array}{c}0.194^{* *} \\
(0.0763)\end{array}$ & $\begin{array}{c}0.242^{* * *} \\
(0.0783)\end{array}$ \\
\hline GOVERNOR TURNOVER RATES_1950_89 & & & & $\begin{array}{r}-1.607^{* *} \\
(0.667)\end{array}$ & $\begin{array}{r}-2.824^{* *} \\
(1.374)\end{array}$ \\
\hline OPENNESS_1980_99 & & & & $\begin{array}{r}0.00469^{* * *} \\
(0.00160)\end{array}$ & $\begin{array}{r}0.00473^{* * *} \\
(0.00134)\end{array}$ \\
\hline TRANSPARENCY_1998 & & & & & $\begin{array}{l}-0.939 \\
(0.566)\end{array}$ \\
\hline EAST ASIA & & & & & $\begin{array}{r}0.522 \\
(0.374)\end{array}$ \\
\hline LATIN & & & & & $\begin{array}{r}1.121 \\
(0.767)\end{array}$ \\
\hline NORDIC & & & & & $\begin{array}{l}0.544^{*} \\
(0.316)\end{array}$ \\
\hline EURO & & & & & $\begin{array}{l}-0.145 \\
(0.328)\end{array}$ \\
\hline Constant & $\begin{array}{r}6.727^{* * *} \\
(0.126)\end{array}$ & $\begin{array}{r}6.869^{* * *} \\
(0.196)\end{array}$ & $\begin{array}{r}6.937^{* * *} \\
(0.735)\end{array}$ & $\begin{array}{r}7.104^{* * *} \\
(0.540)\end{array}$ & $\begin{array}{r}8.151^{* * *} \\
(0.997)\end{array}$ \\
\hline Observations & 62 & 62 & 57 & 49 & 43 \\
\hline R-squared & 0.235 & 0.309 & 0.325 & 0.383 & 0.620 \\
\hline
\end{tabular}

Robust standard errors in parentheses, $* * * p<0.01, * * p<0.05, * p<0.1$

Notes: INFLATION_1980_99 is the average of 'CPI inflation / $100+$ CPI inflation' during 1980-99. UNEMP_1995_99 is an average unemployment rate during 1995-99. INFLATION TARGETING is an indicator variable for adopting inflation targeting as of 1999. COMMUNICATION_1998_2014 is the average number of central bank speeches per month as collected by the Bank for International Settlements (BIS) (source: Lustenberger and Rossi, 2018). GOVERNOR TURNOVER RATES_1950_89 is an average number of changes of central bank governor during 1950-89 and is based on Cukierman et al. (1992) and Vuletin and Zhu (2011). High values mean frequent changes of governor (or low level of actual independence). OPENNESS_1980_99 is the share of exports and imports in GDP. TRANSPARENCY_1998 is based on survey responses targeting central bankers (source: Fry et al.(2000) in Crowe and Meade (2008)). The survey was conducted by the BOE in 1998. 
Table A4. Cross-Section Robustness Check: Median Regression

Reputation $\Rightarrow$ Inflation \& Unemployment

\begin{tabular}{|c|c|c|c|c|c|c|c|c|c|}
\hline \multirow[t]{2}{*}{ Dep Var= } & \multicolumn{3}{|c|}{$\begin{array}{c}\text { INFLATION } \\
(\pi /(100+\pi), 2000-16)\end{array}$} & \multicolumn{3}{|c|}{ S.D. of INFLATION (2000-16) } & \multicolumn{3}{|c|}{$\begin{array}{l}\text { UNEMPLOYMENT RATE } \\
(2000-16)\end{array}$} \\
\hline & (1) & (2) & (3) & (4) & (5) & (6) & (7) & (8) & (9) \\
\hline \multirow[t]{2}{*}{$\begin{array}{l}\text { REPUTATION } \\
\text { (1995-99) }\end{array}$} & $-0.0137^{* * *}$ & $-0.00755^{* *}$ & $-0.00577^{*}$ & $-0.00730^{* * *}$ & $-0.00710^{* * *}$ & $-0.00536^{* *}$ & -0.868 & -0.662 & 0.180 \\
\hline & $(0.00329)$ & $(0.00374)$ & $(0.00340)$ & $(0.00191)$ & $(0.00201)$ & $(0.00250)$ & $(0.568)$ & $(0.735)$ & $(0.495)$ \\
\hline \multirow{2}{*}{$\begin{array}{l}\text { INFLATION } \\
\text { TARGETING } \\
\text { _1999 }\end{array}$} & & -0.00267 & $-0.0124^{*}$ & & -0.00522 & $-0.00866^{*}$ & & & \\
\hline & & $(0.00784)$ & $(0.00698)$ & & $(0.00420)$ & $(0.00514)$ & & & \\
\hline \multirow[t]{2}{*}{$\begin{array}{l}\text { GROWTH } \\
(2000-16)\end{array}$} & & 0.00219 & 0.00124 & & 0.00160 & 0.00179 & & & $-0.564^{* *}$ \\
\hline & & $(0.00194)$ & $(0.00172)$ & & $(0.00104)$ & $(0.00127)$ & & & $(0.273)$ \\
\hline \multirow[t]{2}{*}{$\begin{array}{l}\text { OPENNESS } \\
(2000-16)\end{array}$} & & $-3.14 \mathrm{e}-05$ & $2.34 \mathrm{e}-05$ & & $2.22 \mathrm{e}-05$ & $4.46 \mathrm{e}-05$ & & -0.00684 & 0.00204 \\
\hline & & $(4.90 e-05)$ & $(4.23 e-05)$ & & $(2.63 e-05)$ & $(3.11 \mathrm{e}-05)$ & & $(0.00921)$ & $(0.00666)$ \\
\hline \multirow[t]{2}{*}{$\begin{array}{l}\text { In(GDP per } \\
\text { capita, 1999) }\end{array}$} & & $-0.00601^{*}$ & -0.000803 & & $7.53 e-05$ & 0.00159 & & -0.149 & $-1.189^{* *}$ \\
\hline & & $(0.00358)$ & $(0.00328)$ & & $(0.00192)$ & $(0.00241)$ & & $(0.571)$ & $(0.486)$ \\
\hline \multirow[t]{2}{*}{ EAST ASIA } & & & $-0.0258^{* *}$ & & & -0.0117 & & & -1.033 \\
\hline & & & $(0.00993)$ & & & $(0.00731)$ & & & $(1.555)$ \\
\hline \multirow[t]{2}{*}{ LATIN } & & & 0.00270 & & & 0.00394 & & & 1.033 \\
\hline & & & $(0.00998)$ & & & $(0.00735)$ & & & (1.429) \\
\hline \multirow[t]{2}{*}{ NORDIC } & & & -0.00196 & & & -0.00132 & & & -0.777 \\
\hline & & & $(0.0102)$ & & & $(0.00751)$ & & & (1.613) \\
\hline \multirow[t]{2}{*}{ EURO } & & & $-0.0126^{*}$ & & & -0.00305 & & & $2.602^{* *}$ \\
\hline & & & $(0.00719)$ & & & $(0.00529)$ & & & (1.070) \\
\hline \multirow[t]{2}{*}{$\begin{array}{l}\text { INFLATION } \\
(1980-99)\end{array}$} & & & $0.0994^{* * *}$ & & & $0.0411^{* *}$ & & & \\
\hline & & & $(0.0261)$ & & & $(0.0192)$ & & & \\
\hline \multirow[t]{2}{*}{ Constant } & $0.124^{* * *}$ & $0.134^{* * *}$ & $0.0697^{* *}$ & $0.0680^{* * *}$ & $0.0609^{* * *}$ & 0.0318 & $12.97^{* * *}$ & $13.40^{* * *}$ & $17.56^{* * *}$ \\
\hline & $(0.0221)$ & $(0.0302)$ & $(0.0345)$ & $(0.0128)$ & $(0.0162)$ & $(0.0254)$ & (3.810) & (4.680) & (4.139) \\
\hline Observations & 62 & 62 & 62 & 62 & 62 & 62 & 62 & 62 & 62 \\
\hline
\end{tabular}

Standard errors in parentheses, ${ }^{* * *} p<0.01,{ }^{* *} p<0.05,{ }^{*} p<0.1$

Note: A STATA code "qreg" is used. 

Empirical Evidence from an Executive Survey of 62 Countries

Table A5. Cross-Section Heterogeneity: Low-income 31 (1 $1^{\text {st }}$ Panel) vs. High-income 31 Countries(2 ${ }^{\text {nd }}$ Panel)

First Panel

\begin{tabular}{|c|c|c|c|c|c|c|c|c|c|}
\hline \multirow[t]{2}{*}{ Dep Var= } & \multicolumn{3}{|c|}{ INFLATION (2000-16) } & \multicolumn{3}{|c|}{ S.D. of INFLATION (2000-16) } & \multicolumn{3}{|c|}{$\begin{array}{l}\text { UNEMPLOYMENT RATE } \\
(2000-16)\end{array}$} \\
\hline & (1) & (2) & (3) & (4) & (5) & (6) & (7) & (8) & (9) \\
\hline \multirow{2}{*}{$\begin{array}{l}\text { REPUTATION } \\
\text { (1995-99) }\end{array}$} & $-0.0270^{* * *}$ & $-0.0278^{* * *}$ & $-0.0287^{* *}$ & $-0.0139^{* * *}$ & $-0.0155^{* * *}$ & $-0.0138^{* *}$ & 0.0744 & -0.224 & 0.372 \\
\hline & $(0.00817)$ & $(0.00972)$ & $(0.0110)$ & $(0.00418)$ & $(0.00452)$ & $(0.00649)$ & $(0.544)$ & $(0.631)$ & $(0.840)$ \\
\hline \multirow{2}{*}{$\begin{array}{l}\text { REPUTATION } \\
\text { (1995-99) } \\
\text { XINFLATION }\end{array}$} & & $0.0254^{* *}$ & $0.0237^{*}$ & & $0.0194^{* * *}$ & $0.0203^{* * *}$ & & -0.252 & -0.130 \\
\hline & & $(0.0109)$ & $(0.0130)$ & & $(0.00617)$ & $(0.00654)$ & & $(0.331)$ & $(0.272)$ \\
\hline \multirow{2}{*}{$\begin{array}{l}\text { INFLAATION } \\
\text { TARGETING } \\
\text { _1999 }\end{array}$} & & $-0.194^{* *}$ & $-0.188^{* *}$ & & $-0.149^{* * *}$ & $-0.154^{* * *}$ & & & \\
\hline & & $(0.0783)$ & $(0.0881)$ & & $(0.0444)$ & $(0.0470)$ & & & \\
\hline \multirow[t]{2}{*}{$\begin{array}{l}\text { GROWTH } \\
(2000-16)\end{array}$} & & -0.000841 & 0.00330 & & -0.00151 & 0.000318 & & & -1.218 \\
\hline & & $(0.00456)$ & $(0.00560)$ & & $(0.00264)$ & $(0.00416)$ & & & $(0.773)$ \\
\hline \multirow[t]{2}{*}{$\begin{array}{l}\text { OPENNESS } \\
(2000-16)\end{array}$} & & $-0.000415^{* * *}$ & $-0.000333^{*}$ & & -0.000152 & -0.000105 & & -0.0156 & $-0.0547^{*}$ \\
\hline & & $(0.000139)$ & $(0.000164)$ & & $(8.96 e-05)$ & $(0.000113)$ & & $(0.0230)$ & $(0.0293)$ \\
\hline \multirow[t]{2}{*}{$\begin{array}{l}\text { In(GDP per } \\
\text { capita, 1999) }\end{array}$} & & 0.0106 & 0.0125 & & 0.00768 & 0.0107 & & $1.819^{* *}$ & 0.448 \\
\hline & & $(0.0118)$ & $(0.0131)$ & & $(0.00656)$ & $(0.00992)$ & & $(0.865)$ & (1.257) \\
\hline \multirow[t]{2}{*}{ EAST ASIA } & & & $-0.0477^{*}$ & & & -0.00575 & & & -0.297 \\
\hline & & & $(0.0231)$ & & & $(0.0165)$ & & & (2.839) \\
\hline \multirow[t]{2}{*}{ LATIN } & & & 0.0162 & & & -0.00534 & & & $-4.451^{*}$ \\
\hline & & & $(0.0248)$ & & & $(0.0178)$ & & & (2.272) \\
\hline NORDIC & & & - & & & - & & & - \\
\hline \multirow[t]{2}{*}{ EURO } & & & -0.0129 & & & -0.00539 & & & $4.266^{* *}$ \\
\hline & & & (0.0195) & & & $(0.0101)$ & & & (1.825) \\
\hline \multirow[t]{2}{*}{$\begin{array}{l}\text { INFLATION } \\
(1980-99)\end{array}$} & & & -0.00772 & & & 0.0389 & & & \\
\hline & & & $(0.0540)$ & & & $(0.0411)$ & & & \\
\hline \multirow[t]{2}{*}{ Constant } & $0.221^{* * *}$ & $0.189^{* * *}$ & 0.158 & $0.120^{* * *}$ & $0.0942^{*}$ & 0.0410 & $8.530^{* * *}$ & -2.173 & 13.62 \\
\hline & $(0.0539)$ & $(0.0569)$ & (0.0996) & $(0.0279)$ & $(0.0507)$ & $(0.0769)$ & (2.972) & (6.266) & (9.596) \\
\hline Observations & 31 & 31 & 31 & 31 & 31 & 31 & 31 & 31 & 31 \\
\hline $\mathrm{R}$-squared & 0.445 & 0.632 & 0.681 & 0.311 & 0.515 & 0.548 & 0.000 & 0.096 & 0.360 \\
\hline
\end{tabular}

Robust standard errors in parentheses. ${ }^{* * *} \mathrm{p}<0.01, * * \mathrm{p}<0.05, * \mathrm{p}<0.1$ 
Second Panel

\begin{tabular}{|c|c|c|c|c|c|c|c|c|c|}
\hline \multirow[t]{2}{*}{ Dep Var= } & \multicolumn{3}{|c|}{ INFLATION (2000-16) } & \multicolumn{3}{|c|}{ S.D. of INFLATION (2000-16) } & \multicolumn{3}{|c|}{$\begin{array}{l}\text { UNEMPLOYMENT RATE } \\
(2000-16)\end{array}$} \\
\hline & (1) & (2) & (3) & (4) & (5) & (6) & (7) & (8) & (9) \\
\hline \multirow[t]{2}{*}{$\begin{array}{l}\text { REPUTATION } \\
\text { (1995-99) }\end{array}$} & -0.00130 & -0.00125 & -0.00331 & -0.00168 & $-0.00400^{* *}$ & $-0.00435^{* * *}$ & -0.563 & 0.175 & -0.341 \\
\hline & $(0.00218)$ & $(0.00371)$ & (0.00238) & $(0.00179)$ & $(0.00157)$ & $(0.00137)$ & $(0.638)$ & (0.672) & $(0.655)$ \\
\hline \multirow{2}{*}{$\begin{array}{l}\text { REPUTATION } \\
\text { (1995-99) } \\
\times \text { INFLATION }\end{array}$} & & 0.00233 & -0.00110 & & $0.00524^{*}$ & 0.00365 & & -0.206 & 0.0158 \\
\hline & & $(0.00360)$ & $(0.00415)$ & & $(0.00285)$ & $(0.00243)$ & & $(0.183)$ & $(0.171)$ \\
\hline \multirow{2}{*}{$\begin{array}{l}\text { INFLATION } \\
\text { TARGETING } \\
\text { _1999 }\end{array}$} & & -0.0190 & 0.00122 & & $-0.0448^{* *}$ & $-0.0367^{* *}$ & & & \\
\hline & & $(0.0271)$ & $(0.0291)$ & & (0.0212) & (0.0173) & & & \\
\hline \multirow[t]{2}{*}{$\begin{array}{l}\text { GROWTH } \\
(2000-16)\end{array}$} & & $0.00229^{* * *}$ & $0.00187^{*}$ & & $0.00380^{* * *}$ & $0.00351^{* * *}$ & & & $-0.582^{* * *}$ \\
\hline & & (0.000581) & $(0.000903)$ & & $(0.000534)$ & $(0.000576)$ & & & $(0.200)$ \\
\hline \multirow[t]{2}{*}{$\begin{array}{l}\text { OPENNESS } \\
(2000-16)\end{array}$} & & $-2.24 \mathrm{e}-05^{*}$ & $2.64 \mathrm{e}-05$ & & $-1.34 \mathrm{e}-06$ & $2.23 e-05$ & & $-0.00923^{* *}$ & 0.00190 \\
\hline & & $(1.17 e-05)$ & $(1.76 e-05)$ & & $(1.49 \mathrm{e}-05)$ & $(2.07 e-05)$ & & $(0.00427)$ & $(0.00594)$ \\
\hline \multirow[t]{2}{*}{$\begin{array}{l}\text { In(GDP per } \\
\text { capita, 1999) }\end{array}$} & & -0.00296 & $-0.0117^{* * *}$ & & -0.00325 & $-0.00695^{*}$ & & $-3.037^{*}$ & $-3.059^{*}$ \\
\hline & & $(0.00579)$ & (0.00396) & & $(0.00351)$ & $(0.00364)$ & & (1.734) & $(1.744)$ \\
\hline \multirow[t]{2}{*}{ EAST ASIA } & & & $-0.0204^{* * *}$ & & & $-0.0104^{*}$ & & & -2.029 \\
\hline & & & (0.00703) & & & (0.00588) & & & (1.692) \\
\hline LATIN & & & - & & & - & & & - \\
\hline \multirow[t]{2}{*}{ NORDIC } & & & 0.00480 & & & 0.00151 & & & 0.0109 \\
\hline & & & $(0.00617)$ & & & $(0.00214)$ & & & (0.769) \\
\hline \multirow[t]{2}{*}{ EURO } & & & -0.00632 & & & -0.00427 & & & 1.895 \\
\hline & & & $(0.00627)$ & & & $(0.00355)$ & & & (1.191) \\
\hline \multirow[t]{2}{*}{$\begin{array}{l}\text { INFLATION } \\
(1980-99)\end{array}$} & & & -0.0129 & & & 0.0221 & & & \\
\hline & & & (0.0545) & & & $(0.0230)$ & & & \\
\hline \multirow[t]{2}{*}{ Constant } & $0.0292^{*}$ & 0.0557 & $0.161^{* * *}$ & $0.0272^{* *}$ & $0.0688^{*}$ & $0.109^{* * *}$ & $10.50^{* *}$ & $37.12^{* *}$ & $40.51^{*}$ \\
\hline & (0.0168) & (0.0438) & $(0.0502)$ & (0.0128) & $(0.0356)$ & $(0.0384)$ & $(4.791)$ & (18.05) & (20.32) \\
\hline Observations & 31 & 31 & 31 & 31 & 31 & 31 & 31 & 31 & 31 \\
\hline R-squared & 0.012 & 0.241 & 0.561 & 0.019 & 0.716 & 0.834 & 0.019 & 0.211 & 0.577 \\
\hline
\end{tabular}

Robust standard errors in parentheses, ${ }^{* * *} \mathrm{p}<0.01,{ }^{* *} \mathrm{p}<0.05, * \mathrm{p}<0.1$

Note: Income is based on per capita GDP in 1999. 

Empirical Evidence from an Executive Survey of 62 Countries

\section{Table A6. Cross-Section Further Results:}

Countries that experienced negative inflation rates were excluded

\begin{tabular}{|c|c|c|c|c|c|c|c|c|c|}
\hline \multirow[t]{2}{*}{ Dep Var= } & \multicolumn{3}{|c|}{$\begin{array}{c}\text { INFLATION } \\
(\pi /(100+\pi), 2000-16)\end{array}$} & \multicolumn{3}{|c|}{ S.D. of INFLATION (2000-16) } & \multicolumn{3}{|c|}{$\begin{array}{l}\text { UNEMPLOYMENT RATE } \\
(2000-16)\end{array}$} \\
\hline & (1) & (2) & (3) & (4) & (5) & (6) & (7) & (8) & (9) \\
\hline \multirow[t]{2}{*}{$\begin{array}{l}\text { REPUTATION } \\
\text { (1995-99) }\end{array}$} & & $-0.0231^{* *}$ & $-0.0206^{* *}$ & $-0.0121^{* * *}$ & $-0.0144^{* * *}$ & $-0.0110^{* *}$ & $-0.615^{*}$ & -0.206 & -0.00142 \\
\hline & (0.00568) & (0.00895) & (0.00934) & (0.00298) & $(0.00396)$ & $(0.00508)$ & $(0.323)$ & $(0.494)$ & $(0.515)$ \\
\hline \multirow{2}{*}{$\begin{array}{l}\text { REPUTATION } \\
\text { (1995-99) } \\
\text { XINFLATION }\end{array}$} & & $0.0163^{*}$ & $0.0185^{* *}$ & & $0.0117^{* * *}$ & $0.0122^{* *}$ & & -0.117 & -0.00404 \\
\hline & & (0.00829) & $(0.00915)$ & & $(0.00400)$ & (0.00491) & & $(0.160)$ & $(0.221)$ \\
\hline \multirow{2}{*}{$\begin{array}{l}\text { INFLATION } \\
\text { TARGETING } \\
\text { _1999 }\end{array}$} & & $-0.125^{* *}$ & $-0.152^{* *}$ & & $-0.0919^{* * *}$ & $-0.101^{* * *}$ & & & \\
\hline & & (0.0602) & $(0.0675)$ & & (0.0288) & $(0.0365)$ & & & \\
\hline \multirow[t]{2}{*}{$\begin{array}{l}\text { GROWTH } \\
(2000-16)\end{array}$} & & 0.000998 & 0.000320 & & 0.00178 & 0.00175 & & & $-0.678^{* *}$ \\
\hline & & $(0.00159)$ & (0.00158) & & $(0.00147)$ & $(0.00140)$ & & & (0.303) \\
\hline \multirow[t]{2}{*}{$\begin{array}{l}\text { OPENNESS } \\
(2000-16)\end{array}$} & & $-6.42 \mathrm{e}-05$ & $-1.16 e-05$ & & $-1.01 e-05$ & $1.17 \mathrm{e}-05$ & & $-0.0115^{*}$ & -0.00846 \\
\hline & & $(5.66 \mathrm{e}-05)$ & $(4.06 e-05)$ & & $(3.55 e-05)$ & $(2.99 e-05)$ & & $(0.00659)$ & $(0.00754)$ \\
\hline \multirow[t]{2}{*}{$\begin{array}{l}\text { In(GDP per } \\
\text { capita, 1999) }\end{array}$} & & -0.000410 & 0.00312 & & 0.00180 & $0.00528^{* *}$ & & -0.332 & $-1.221^{* * *}$ \\
\hline & & $(0.00416)$ & $(0.00381)$ & & $(0.00246)$ & $(0.00259)$ & & $(0.493)$ & $(0.442)$ \\
\hline \multirow[t]{2}{*}{ EAST ASIA } & & & -0.00698 & & & -0.00396 & & & -1.178 \\
\hline & & & $(0.0110)$ & & & $(0.00617)$ & & & $(1.402)$ \\
\hline \multirow[t]{2}{*}{ LATIN } & & & 0.0290 & & & 0.00271 & & & -0.524 \\
\hline & & & $(0.0257)$ & & & $(0.0146)$ & & & (1.392) \\
\hline \multirow[t]{2}{*}{ NORDIC } & & & -0.00812 & & & -0.00882 & & & -1.917 \\
\hline & & & $(0.00965)$ & & & $(0.00666)$ & & & (1.507) \\
\hline \multirow[t]{2}{*}{ EURO } & & & $-0.0190^{* *}$ & & & -0.00907 & & & 1.975 \\
\hline & & & (0.00923) & & & $(0.00547)$ & & & (1.623) \\
\hline \multirow[t]{2}{*}{$\begin{array}{l}\text { INFLATION } \\
(1980-99)\end{array}$} & & & 0.0257 & & & 0.0549 & & & \\
\hline & & & $(0.0523)$ & & & $(0.0387)$ & & & \\
\hline \multirow[t]{2}{*}{ Constant } & $0.189^{* * *}$ & $0.204^{* * *}$ & $0.156^{* *}$ & $0.106^{* * *}$ & $0.103^{* * *}$ & 0.0435 & $11.91^{* * *}$ & $13.38^{* * *}$ & $21.51^{* * *}$ \\
\hline & (0.0402) & (0.0338) & (0.0583) & $(0.0214)$ & (0.0278) & $(0.0357)$ & (2.202) & (3.195) & (3.906) \\
\hline Observations & 54 & 54 & 54 & 54 & 54 & 54 & 54 & 54 & 54 \\
\hline R-squared & 0.455 & 0.536 & 0.663 & 0.339 & 0.468 & 0.583 & 0.028 & 0.069 & 0.258 \\
\hline
\end{tabular}

Robust standard errors in parentheses, ${ }^{* * *} p<0.01,{ }^{* *} p<0.05,{ }^{*} p<0.1$

Notes: Eight countries that experienced negative inflation rates in terms of three-year average during 2001-2015 ( $t=3-7$ in Table A1) are dropped from the sample. They are as follows: Bulgaria, Greece, Hong Kong, Japan, Saudi Arabia, Sweden, Switzerland, and Taiwan. 


\section{Table A7. Panel Data: Two-Way Relationship Inflation, Unemployment rate $=>$ Reputation}

\begin{tabular}{|c|c|c|c|c|c|c|}
\hline \multirow{3}{*}{ VARIABLES } & \multicolumn{6}{|c|}{ Dep. Variable $=$ REPUTA TION } \\
\hline & \multicolumn{4}{|c|}{ Fixed effect } & \multirow{2}{*}{$\begin{array}{c}\begin{array}{c}\text { Random } \\
\text { effect }\end{array} \\
(5)\end{array}$} & \multirow{2}{*}{$\begin{array}{l}\text { AB Diff } \\
\text { GMM } \\
(6)\end{array}$} \\
\hline & (1) & (2) & (3) & (4) & & \\
\hline \multirow[t]{2}{*}{$I_{N F L A T I O N}$} & $-4.405^{* * *}$ & $-4.208^{* * *}$ & $-4.261^{* * *}$ & -2.378 & $-6.354^{* *}$ & $-9.238^{*}$ \\
\hline & $(1.318)$ & $(1.314)$ & $(1.346)$ & $(1.695)$ & (2.929) & (4.982) \\
\hline \multirow[t]{2}{*}{ S.D._INFLATION ${ }_{i t}$} & & -2.565 & -1.166 & -0.432 & -1.211 & 4.610 \\
\hline & & $(1.876)$ & $(1.877)$ & (3.343) & $(4.986)$ & (7.989) \\
\hline \multirow{2}{*}{$G D P_{-} G A P_{i t}$} & & $6.063^{*}$ & 4.263 & $11.47^{* * *}$ & $16.41^{* *}$ & $17.11^{* *}$ \\
\hline & & $(3.080)$ & (2.823) & (3.690) & (7.804) & $(6.250)$ \\
\hline \multirow[t]{2}{*}{$U N E M P R A T E_{i t}$} & & $-0.0909^{* * *}$ & $-0.0863^{* * *}$ & $-0.0694^{* * *}$ & -0.00972 & $-0.0769^{* *}$ \\
\hline & & $(0.0208)$ & $(0.0199)$ & $(0.0180)$ & $(0.0135)$ & $(0.0280)$ \\
\hline \multirow[t]{2}{*}{ CRISIS DUMMY $Y_{i t}$} & & & $-0.599^{* * *}$ & $-0.578^{* * *}$ & -0.499 & -0.668 \\
\hline & & & $(0.156)$ & $(0.168)$ & $(0.491)$ & $(0.644)$ \\
\hline \multirow[t]{2}{*}{ REPUTA TION $_{i t-1}$} & & & & $0.309^{* * *}$ & $0.762^{* * *}$ & $0.485^{* * *}$ \\
\hline & & & & $(0.0645)$ & $(0.0596)$ & $(0.100)$ \\
\hline \multirow[t]{2}{*}{$M O N E Y$ GROWTH $H_{i t}$} & & & & & 0.0116 & -0.00203 \\
\hline & & & & & $(0.00782)$ & $(0.0104)$ \\
\hline \multirow[t]{2}{*}{$\begin{array}{l}\text { EFFECTIVE } \\
E X R A T E_{i t}\end{array}$} & & & & & -0.00596 & -0.00231 \\
\hline & & & & & $(0.00478)$ & $(0.00748)$ \\
\hline \multirow[t]{2}{*}{$\begin{array}{l}\text { INFLA TION } \\
\text { TARGETING } G_{i t}\end{array}$} & & & & & -0.0143 & 0.125 \\
\hline & & & & & $(0.136)$ & $(0.220)$ \\
\hline \multirow[t]{2}{*}{ Constant } & $7.147^{* * *}$ & $7.886^{* * *}$ & $7.823^{* * *}$ & $5.446^{* * *}$ & $2.194^{* * *}$ & $4.091^{* * *}$ \\
\hline & $(0.144)$ & $(0.201)$ & $(0.175)$ & $(0.505)$ & $(0.579)$ & $(0.999)$ \\
\hline Time Fixed Effects & $\mathrm{O}$ & $\mathrm{O}$ & $\mathrm{O}$ & $\mathrm{O}$ & $\mathrm{O}$ & $\mathrm{O}$ \\
\hline Country Fixed Effects & O & $\mathrm{O}$ & O & 0 & - & 0 \\
\hline Observations & 437 & 377 & 377 & 315 & 164 & 164 \\
\hline Number of Country $(\mathrm{N})$ & 62 & 62 & 62 & 60 & 30 & 30 \\
\hline $\mathrm{R}$-squared & 0.198 & 0.315 & 0.345 & 0.416 & - & - \\
\hline$A R(1)$ test ( $p$-value) & - & - & - & - & - & 0.006 \\
\hline$A R(2)$ test ( $p$-value) & - & - & - & - & - & 0.370 \\
\hline Sargan test ( $p-$ value) & - & - & - & - & - & 0.000 \\
\hline Hansen $J$ test ( $p-$ value) & - & - & - & - & - & 1.000 \\
\hline
\end{tabular}

Robust standard errors in parentheses. ${ }^{* * *} p<0.01, * * p<0.05, * p<0.1$ 
Table A8. Panel Data Robustness Check 1 (More Controls):

Financial Crisis and Eurozone Indicator Variables \& Openness Variable Included

\begin{tabular}{|c|c|c|c|c|c|c|c|c|c|}
\hline \multirow{3}{*}{$\begin{array}{c}\text { Dep Var= } \\
\text { VARIABLES }\end{array}$} & \multicolumn{3}{|c|}{$I_{N F L A T I O N_{i t}}$} & \multicolumn{3}{|c|}{ S.D._INFLA TION } & \multicolumn{3}{|c|}{$\begin{array}{c}\text { UNEMPLOYMENT } \\
\text { RATE } \\
\end{array}$} \\
\hline & \multicolumn{2}{|c|}{ Fixed Effect Panel } & \multirow{2}{*}{$\begin{array}{l}\begin{array}{l}\text { AB Diff } \\
\text { GMM }\end{array} \\
(3)\end{array}$} & \multicolumn{2}{|c|}{$\begin{array}{l}\text { Fixed Effect } \\
\text { Panel }\end{array}$} & \multirow{2}{*}{$\begin{array}{l}\text { AB Diff } \\
\text { GMM } \\
(6)\end{array}$} & \multicolumn{2}{|c|}{$\begin{array}{l}\text { Fixed Effect } \\
\text { Panel }\end{array}$} & \multirow{2}{*}{$\begin{array}{l}\begin{array}{l}\text { AB Diff } \\
\text { GMM }\end{array} \\
(9)\end{array}$} \\
\hline & $(1)$ & (2) & & (4) & (5) & & (7) & (8) & \\
\hline \multirow[t]{2}{*}{ REPUTA TION } & $-0.0113^{* *}$ & $-0.0165^{* * *}$ & $-0.00836^{* *}$ & $-0.00719^{*}$ & $-0.00634^{*}$ & -0.00664 & $-0.948^{* *}$ & $-0.826 * *$ & k $\quad-0.464$ \\
\hline & $(0.00484)$ & $(0.00602)$ & $(0.00351)$ & $(0.00375)$ & $(0.00327)$ & $(0.00455)$ & $(0.380)$ & $(0.396)$ & $(0.294)$ \\
\hline \multirow[t]{2}{*}{$G D P_{-} G A P_{i t}$} & & -0.163 & $0.524^{* *}$ & & -0.153 & 0.240 & & $-75.02^{* * *}$ & ${ }^{k}-79.86^{* * *}$ \\
\hline & & $(0.231)$ & $(0.208)$ & & $(0.156)$ & $(0.205)$ & & $(11.45)$ & (20.74) \\
\hline \multirow[t]{2}{*}{ UNEMP RATE } & & $-0.00399^{* *}$ & -0.00118 & & 0.000297 & $3.05 e-05$ & & & \\
\hline & & $(0.00166)$ & $(0.00125)$ & & (0.000402) & $(0.000848)$ & & & \\
\hline \multirow[t]{2}{*}{ OPENNESS $S_{i t}$} & & 0.000199 & -0.000148 & & $2.49 \mathrm{e}-05$ & $-8.72 e-05$ & & $0.0238^{* *}$ & ${ }^{k}-0.0103$ \\
\hline & & $(0.000158)$ & $(0.000134)$ & & $(4.97 e-05)$ & $(0.000105)$ & & $(0.00955)$ & $(0.0108)$ \\
\hline \multirow[t]{2}{*}{$\begin{array}{l}\text { DEPENDENT } \\
\text { VARIABLE }\end{array}$} & & & $0.387^{* * *}$ & & & $0.292^{* * *}$ & & & $0.552^{* * *}$ \\
\hline & & & (0.0566) & & & (0.0984) & & & $(0.107)$ \\
\hline \multirow[t]{2}{*}{$\begin{array}{l}\text { MONEY } \\
\text { GROWTH }\end{array}$} & & & $0.000510^{*}$ & & & $-1.75 e-05$ & & & $-0.0588^{* *}$ \\
\hline & & & (0.000258) & & & $(0.000291)$ & & & (0.0271) \\
\hline \multirow[t]{2}{*}{$\begin{array}{l}E F F E C T I V E \\
E X R A T E_{i t}\end{array}$} & & & $-0.000361^{* *}$ & & & -0.000166 & & & -0.0257 \\
\hline & & & (0.000168) & & & (0.000183) & & & $(0.0156)$ \\
\hline \multirow[t]{2}{*}{$\begin{array}{l}\text { INFLA TION } \\
\text { TARGETING }_{i t}\end{array}$} & & & -0.00787 & & & -0.00703 & & & 0.665 \\
\hline & & & $(0.00696)$ & & & $(0.00610)$ & & & $(0.854)$ \\
\hline \multirow[t]{2}{*}{$I N F L A T I O N_{i t}$} & & & & & & & & $-11.38^{* * *}$ & 6.528 \\
\hline & & & & & & & & $(3.868)$ & (5.092) \\
\hline \multirow[t]{2}{*}{$E U R O Z O N E_{i t}$} & 0.00905 & 0.00437 & & 0.00202 & 0.00380 & & -1.221 & -0.942 & \\
\hline & (0.0118) & $(0.0114)$ & & (0.00492) & $(0.00519)$ & & $(0.940)$ & $(0.862)$ & \\
\hline $\begin{array}{l}\text { FINANCIAL } \\
\text { CRISIS DUMMIES }\end{array}$ & $\mathrm{O}$ & $\mathrm{O}$ & $\mathrm{O}$ & $\mathrm{O}$ & $\mathrm{O}$ & $\mathrm{O}$ & $\mathrm{O}$ & $\mathrm{O}$ & $\mathrm{O}$ \\
\hline $\begin{array}{l}\text { Time Fixed } \\
\text { Effects }\end{array}$ & O & $\mathrm{O}$ & $\mathrm{O}$ & $\mathrm{O}$ & $\mathrm{O}$ & $\mathrm{O}$ & O & $\mathrm{O}$ & $\mathrm{O}$ \\
\hline $\begin{array}{l}\text { County Fixed } \\
\text { Effects }\end{array}$ & $\mathrm{O}$ & $\mathrm{O}$ & $\mathrm{O}$ & $\mathrm{O}$ & $\mathrm{O}$ & $\mathrm{O}$ & $\mathrm{O}$ & $\mathrm{O}$ & O \\
\hline \multirow[t]{2}{*}{ Constant } & $0.155^{* * *}$ & $0.209^{* * *}$ & $0.122^{* *}$ & $0.0727^{* *}$ & $0.0634^{* * *}$ & 0.0826 & $14.46^{* * *}$ & $13.10^{* * *}$ & 9.268** \\
\hline & (0.0392) & $(0.0490)$ & $(0.0482)$ & $(0.0297)$ & $(0.0233)$ & $(0.0541)$ & (2.390) & $(2.938)$ & (3.537) \\
\hline Observations( $\left(N^{*} t\right)$ & 437 & 378 & 169 & 377 & 377 & 169 & 440 & 378 & 169 \\
\hline Number of Country(N) & 62 & 62 & 31 & 62 & 62 & 31 & 62 & 62 & 31 \\
\hline $\mathrm{R}$-squared & 0.262 & 0.284 & - & 0.289 & 0.295 & - & 0.184 & 0.340 & - \\
\hline AR(1) Test ( $p$-value) & - & - & 0.022 & - & - & 0.013 & - & - & 0.019 \\
\hline AR(2) Test ( $p$-value) & - & - & 0.914 & - & - & 0.604 & - & - & 0.218 \\
\hline Sargan Test (p-value) & - & - & 0.037 & - & - & 0.000 & - & - & 0.000 \\
\hline Hensen J Test (p-value) & - & - & 1.000 & - & - & 1.000 & - & - & 1.000 \\
\hline
\end{tabular}

Robust standard errors in parentheses, ${ }^{* * *} \mathrm{p}<0.01,{ }^{* *} \mathrm{p}<0.05,{ }^{*} \mathrm{p}<0.1$

Note: Most financial crisis dummies are estimated to have significant negative signs (results are omitted). 
Table A9. Panel Data Robustness Check 2 (Estimation Method):

Random-Effect Panel Model Estimated

\begin{tabular}{|c|c|c|c|c|c|c|c|c|c|}
\hline \multirow{2}{*}{$\begin{array}{c}\text { Dep Var= } \\
\text { VARIABLES }\end{array}$} & \multicolumn{3}{|c|}{$I N F L A T I O N_{i t}$} & \multicolumn{3}{|c|}{ S.D._INFLATION } & \multicolumn{3}{|c|}{$\begin{array}{c}\text { UNEMPLOYMENT } \\
R A T E_{i t} \\
\end{array}$} \\
\hline & (1) & (2) & (3) & (4) & (5) & (6) & (7) & (8) & (9) \\
\hline \multirow[t]{2}{*}{ REPUTA TION } & $-0.0163^{* * *}$ & $-0.0177^{* * *}$ & $-0.00657^{* * *}$ & $-0.00968^{* * *}$ & $-0.00879^{* * *}$ & $-0.00420^{* *}$ & $-0.931^{* * *}$ & $-1.351^{* * *}$ & -0.179 \\
\hline & $(0.00471)$ & (0.00483) & $(0.00216)$ & $(0.00264)$ & $(0.00288)$ & $(0.00214)$ & $(0.312)$ & $(0.353)$ & $(0.122)$ \\
\hline \multirow[t]{2}{*}{$G D P_{-} G A P_{i t}$} & & $0.420^{*}$ & 0.330 & & 0.0151 & -0.0303 & & $-60.30^{* * *}$ & $-88.09^{* * *}$ \\
\hline & & $(0.229)$ & $(0.204)$ & & $(0.196)$ & $(0.163)$ & & $(15.57)$ & (20.05) \\
\hline \multirow[t]{2}{*}{$U N E M P R A T E_{i t}$} & & $-0.00179^{*}$ & 0.000226 & & -0.000447 & $5.28 e-05$ & & & \\
\hline & & $(0.000925)$ & $(0.000443)$ & & $(0.000313)$ & $(0.000140)$ & & & \\
\hline \multirow[t]{2}{*}{$\begin{array}{l}E F F E C T I V E \\
E X R A T E_{i t}\end{array}$} & & $-0.00147^{* * *}$ & $-0.000276^{* *}$ & & $-0.000549^{* * *}$ & -0.000114 & & $-0.0612^{* * *}$ & 0.00901 \\
\hline & & $(0.000395)$ & $(0.000108)$ & & (0.000198) & $(8.55 e-05)$ & & $(0.0166)$ & $(0.0106)$ \\
\hline \multirow[t]{2}{*}{$\begin{array}{l}\text { MONEY } \\
\text { GROWTH }\end{array}$} & & & $0.00110^{* * *}$ & & & 0.000147 & & & $\begin{array}{r}-0.0599 \\
* * *\end{array}$ \\
\hline & & & $(0.000256)$ & & & $(0.000227)$ & & & $(0.0210)$ \\
\hline \multirow[t]{2}{*}{$\begin{array}{l}\text { INFLATION } \\
\text { TARGETING } \\
\text { it }\end{array}$} & & & $-0.00607^{*}$ & & & $-0.00465^{*}$ & & & 0.306 \\
\hline & & & (0.00339) & & & $(0.00254)$ & & & $(0.188)$ \\
\hline \multirow[t]{2}{*}{$\begin{array}{l}D E P E N D E N T \\
V A R I A B L E_{i t-1}\end{array}$} & & & $0.398^{* * *}$ & & & $0.282^{* * *}$ & & & $0.920 * * *$ \\
\hline & & & $(0.0441)$ & & & (0.103) & & & $(0.0708)$ \\
\hline \multirow[t]{2}{*}{$I_{N F L A T I O N}$} & & & & & & & & $-13.63^{* *}$ & $9.654^{*}$ \\
\hline & & & & & & & & $(5.835)$ & $(5.055)$ \\
\hline \multirow[t]{2}{*}{ Constant } & $0.117^{* * *}$ & $0.289^{* * *}$ & $0.0758^{* * *}$ & $0.0734^{* * *}$ & $0.125^{* * *}$ & $0.0527^{* *}$ & $12.74^{* * *}$ & $23.24^{* * *}$ & 0.354 \\
\hline & $(0.0304)$ & $(0.0690)$ & $(0.0229)$ & $(0.0174)$ & $(0.0387)$ & $(0.0261)$ & (2.150) & (3.627) & $(1.878)$ \\
\hline Time Fixed-Effect & $\mathrm{O}$ & $\mathrm{O}$ & $\mathrm{O}$ & $\mathrm{O}$ & $\mathrm{O}$ & $\mathrm{O}$ & $\mathrm{O}$ & $\mathrm{O}$ & $\mathrm{O}$ \\
\hline Observations & 437 & 288 & 169 & 377 & 288 & 169 & 440 & 288 & 169 \\
\hline Number of Country(N) & 62 & 45 & 31 & 62 & 45 & 31 & 62 & 45 & 31 \\
\hline
\end{tabular}

Robust standard errors in parentheses, *** $\mathrm{p}<0.01, * * \mathrm{p}<0.05, * \mathrm{p}<0.1$ 

Empirical Evidence from an Executive Survey of 62 Countries

Table A10. Panel Data Robustness Check 3 (Data Frequency):

Yearly Data (Instead of 3-year Averaged Data) Used

\begin{tabular}{|c|c|c|c|c|c|c|c|}
\hline \multirow{3}{*}{$\begin{array}{l}\text { Dep Var= } \\
\text { VARIABLES }\end{array}$} & \multicolumn{4}{|c|}{$I_{N F L A T I O N}$} & \multicolumn{3}{|c|}{ UNEMPLOYMENT RATE } \\
\hline & \multicolumn{3}{|c|}{ Fixed Effect Panel } & \multirow{2}{*}{$\begin{array}{c}\begin{array}{c}\text { AB Diff } \\
\text { GMM }\end{array} \\
(4)\end{array}$} & \multicolumn{2}{|c|}{ Fixed Effect Panel } & \multirow{2}{*}{$\begin{array}{c}\begin{array}{c}\text { AB Diff } \\
\text { GMM }\end{array} \\
(7)\end{array}$} \\
\hline & (1) & (2) & (3) & & (5) & (6) & \\
\hline \multirow[t]{2}{*}{ REPUTA TION ${ }_{i t}$} & $-0.0124^{* *}$ & $-0.0104^{* *}$ & -0.00292 & $-0.00673^{* *}$ & $-0.773^{* * *}$ & $-0.170^{* * *}$ & -0.0637 \\
\hline & (0.00482) & $(0.00486)$ & (0.00190) & $(0.00258)$ & $(0.261)$ & $(0.0613)$ & $(0.0618)$ \\
\hline \multirow{2}{*}{$G D P_{-} G A P_{i t}$} & & -0.163 & $-0.242^{*}$ & -0.212 & & $-16.61^{* * *}$ & $-14.27^{* * *}$ \\
\hline & & $(0.140)$ & $(0.142)$ & $(0.132)$ & & (3.960) & (3.970) \\
\hline \multirow[t]{2}{*}{$\begin{array}{l}\text { EFFECTIVE } \\
\text { EX RATE }\end{array}$} & & $-0.00129^{* * *}$ & $-0.000700^{* * *}$ & $-0.000812^{* * *}$ & & 0.00543 & $0.00879^{*}$ \\
\hline & & $(0.000367)$ & $(0.000210)$ & (0.000223) & & $(0.00439)$ & $(0.00470)$ \\
\hline \multirow{2}{*}{ UNEMP RATE } & & $-0.00307^{* * *}$ & $-0.00169^{*}$ & $-0.00142^{*}$ & & & \\
\hline & & $(0.000650)$ & $(0.000857)$ & $(0.000715)$ & & & \\
\hline \multirow{2}{*}{$\begin{array}{l}\text { MONEY } \\
\text { GROWTH }\end{array}$} & & & 0.000295 & 0.000262 & & -0.00962 & -0.0103 \\
\hline & & & $(0.000177)$ & $(0.000174)$ & & $(0.00608)$ & $(0.00645)$ \\
\hline \multirow{2}{*}{$\begin{array}{l}\text { INFLA TION } \\
\text { TARGETING } \\
\text { it }\end{array}$} & & & -0.0109 & -0.00287 & & 0.00730 & 0.114 \\
\hline & & & $(0.00788)$ & $(0.00460)$ & & $(0.310)$ & $(0.141)$ \\
\hline \multirow{2}{*}{$\begin{array}{l}\text { DEPENDENT } \\
\text { VARIABLE }\end{array}$} & & & $0.420^{* * *}$ & $0.468^{* * *}$ & & $0.789^{* * *}$ & $0.916^{* * *}$ \\
\hline & & & (0.0904) & $(0.120)$ & & (0.0293) & $(0.0319)$ \\
\hline \multirow[t]{2}{*}{$I_{N F L A T I O N}$} & & & & & & 2.295 & 2.486 \\
\hline & & & & & & (1.963) & (1.628) \\
\hline \multirow[t]{2}{*}{ Constant } & $0.161^{* * *}$ & $0.271^{* * *}$ & $0.120^{* * *}$ & $0.146^{* * *}$ & $13.34^{* * *}$ & $2.671^{* * *}$ & -0.307 \\
\hline & $(0.0378)$ & $(0.0641)$ & $(0.0327)$ & $(0.0434)$ & $(1.660)$ & $(0.672)$ & (0.588) \\
\hline $\begin{array}{l}\text { Time Fixed } \\
\text { Effects }\end{array}$ & $\mathrm{O}$ & $\mathrm{O}$ & $\mathrm{O}$ & $\mathrm{O}$ & $\mathrm{O}$ & $\mathrm{O}$ & $\mathrm{O}$ \\
\hline $\begin{array}{l}\text { County Fixed } \\
\text { Effects }\end{array}$ & $\mathrm{O}$ & $\mathrm{O}$ & $\mathrm{O}$ & $\mathrm{O}$ & $\mathrm{O}$ & $\mathrm{O}$ & $\mathrm{O}$ \\
\hline Observations $\left(N^{*} t\right)$ & 1,172 & 854 & 546 & 546 & 1,177 & 546 & 546 \\
\hline Number of Country(N) & 62 & 45 & 31 & 31 & 62 & 31 & 31 \\
\hline $\mathrm{R}$-squared & 0.198 & 0.326 & 0.549 & - & 0.133 & 0.781 & - \\
\hline AR(1) Test ( $p$-value) & - & - & - & 0.067 & - & - & 0.003 \\
\hline AR(2) Test ( $p$-value) & - & - & - & 0.016 & - & - & 0.176 \\
\hline Sargan Test ( $p$-value) & - & - & - & 0.000 & - & - & 0.000 \\
\hline Hansen J Test ( $p$-value) & - & - & - & 1.000 & - & - & 1.000 \\
\hline
\end{tabular}

Robust standard errors in parentheses. ${ }^{* * *} \mathrm{p}<0.01,{ }^{* *} \mathrm{p}<0.05,{ }^{*} \mathrm{p}<0.1$ 
Table A11. Role of Reputation in Low-Inflation Economies:

Sample Limited to Those Countries Whose Inflation Rates Are Never above 5 Percent* during 1995-2016

\begin{tabular}{|c|c|c|c|c|c|c|c|c|c|c|}
\hline \multirow{3}{*}{$\begin{array}{c}\text { Dep Var= } \\
\text { VARIABLES }\end{array}$} & \multicolumn{4}{|c|}{$I N F L A T I O N_{i t}$} & \multicolumn{3}{|c|}{ S.D._INFLATION $N_{i t}$} & \multicolumn{3}{|c|}{$\begin{array}{c}\text { UNEMPLOYMENT } \\
R A T E_{i t}\end{array}$} \\
\hline & \multicolumn{3}{|c|}{ Fixed Effect Panel } & \multirow{2}{*}{$\begin{array}{c}\begin{array}{c}\text { AB Diff } \\
\text { GMM }\end{array} \\
(4)\end{array}$} & \multicolumn{2}{|c|}{$\begin{array}{l}\text { Fixed Effect } \\
\text { Panel }\end{array}$} & \multirow{2}{*}{$\begin{array}{c}\begin{array}{c}\text { AB Diff } \\
\text { GMM }\end{array} \\
(7)\end{array}$} & \multicolumn{2}{|c|}{$\begin{array}{l}\text { Fixed Effect } \\
\text { Panel }\end{array}$} & \multirow{2}{*}{$\begin{array}{c}\text { AB } \\
\text { Diff } \\
\text { GMM } \\
(10)\end{array}$} \\
\hline & $(1)$ & (2) & (3) & & (5) & (6) & & (8) & (9) & \\
\hline \multirow{2}{*}{$R E P U T A T I O N_{i t}$} & $-0.00932^{* *}$ & $-0.00910^{* *}$ & -0.00298 & $-0.0163^{* *}$ & $-0.00946^{* *}$ & $-0.00927^{*}$ & $-0.0160^{* * *}$ & $-1.236^{* * *}$ & $-1.244^{* *}$ & -0.298 \\
\hline & $(0.00372)$ & $(0.00422)$ & $(0.00355)$ & $(0.00524)$ & $(0.00417)$ & $(0.00446)$ & $(0.00335)$ & $(0.397)$ & $(0.435)$ & $(0.449)$ \\
\hline \multirow[t]{2}{*}{$G D P_{-} G A P_{i t}$} & & $1.063^{* *}$ & $1.476^{*}$ & $1.819^{*}$ & & 0.736 & 0.790 & & $-132.7^{*}$ & $-165.1^{* *}$ \\
\hline & & (0.393) & $(0.777)$ & $(0.841)$ & & $(0.704)$ & $(0.836)$ & & $(63.66)$ & $(60.82)$ \\
\hline \multirow[t]{2}{*}{$\begin{array}{l}\text { EFFECTIVE } \\
E X R A T E_{i t}\end{array}$} & & $-0.000670^{*}$ & $-0.000533^{*}$ & -0.000386 & & -0.000606 & -0.000528 & & -0.00245 & 0.00406 \\
\hline & & $(0.000338)$ & $(0.000246)$ & $(0.000221)$ & & $(0.000406)$ & $(0.000396)$ & & $(0.0235)$ & $(0.0306)$ \\
\hline \multirow[t]{2}{*}{$U N E M P R A T E_{i t}$} & & $-0.00169^{* * *}$ & 0.00106 & 0.00113 & & 0.000613 & $4.49 e-05$ & & & \\
\hline & & $(0.000560)$ & $(0.00203)$ & $(0.00171)$ & & $(0.000777)$ & $(0.000903)$ & & & \\
\hline \multirow[t]{2}{*}{$\begin{array}{l}\text { MONEY } \\
\text { GROWTH }\end{array}$} & & & 0.000183 & 0.000554 & & -0.000347 & -0.000169 & & -0.00755 & -0.00413 \\
\hline & & & $(0.000158)$ & $(0.000340)$ & & $(0.000282)$ & $(0.000266)$ & & $(0.0221)$ & $(0.0225)$ \\
\hline \multirow[t]{2}{*}{$\begin{array}{l}D E P E N D E N T \\
V A R I A B L E_{i t-1}\end{array}$} & & & 0.0641 & 0.165 & & 0.144 & $0.429^{*}$ & & $0.305^{* * *}$ & $0.422^{* * *}$ \\
\hline & & & $(0.222)$ & $(0.176)$ & & $(0.238)$ & $(0.208)$ & & $(0.0890)$ & (0.109) \\
\hline \multirow[t]{2}{*}{$\begin{array}{l}\text { INFLATION } \\
\text { TARGETING }\end{array}$} & & & & -0.00403 & & & -0.00325 & & & 2.337 \\
\hline & & & & (0.00929) & & & $(0.00315)$ & & & $(1.747)$ \\
\hline \multirow[t]{2}{*}{ INFLATION } & & & & & & & & & $22.96 *$ & 17.97 \\
\hline & & & & & & & & & $(11.35)$ & (13.42) \\
\hline \multirow[t]{2}{*}{ Constant } & $0.0876^{* * *}$ & $0.159^{* * *}$ & $0.0907^{* *}$ & $0.159^{* * *}$ & $0.0687^{* *}$ & $0.129^{*}$ & $0.179^{* *}$ & $17.56^{* * *}$ & $13.77^{* *}$ & 4.355 \\
\hline & $(0.0231)$ & $(0.0519)$ & $(0.0372)$ & $(0.0354)$ & $(0.0263)$ & $(0.0657)$ & $(0.0636)$ & (2.752) & $(5.229)$ & (5.630) \\
\hline $\begin{array}{l}\text { Time Fixed } \\
\text { Effects }\end{array}$ & $\mathrm{O}$ & $\mathrm{O}$ & $\mathrm{O}$ & $\mathrm{O}$ & $\mathrm{O}$ & $\mathrm{O}$ & $\mathrm{O}$ & $\mathrm{O}$ & $\mathrm{O}$ & $\mathrm{O}$ \\
\hline $\begin{array}{l}\text { County Fixed } \\
\text { Effects }\end{array}$ & $\mathrm{O}$ & $\mathrm{O}$ & $\mathrm{O}$ & $\mathrm{O}^{\mathrm{a}}$ & O & $\mathrm{O}$ & $\mathrm{O}^{\mathrm{a}}$ & $\mathrm{O}$ & $\mathrm{O}$ & $\mathrm{O}^{\mathrm{a}}$ \\
\hline Observations $\left(N^{*} t\right)$ & 174 & 130 & 61 & 61 & 150 & 61 & 61 & 175 & 61 & 61 \\
\hline Number of Country(N) & 25 & 20 & 12 & 12 & 25 & 12 & 12 & 25 & 12 & 12 \\
\hline R-squared & 0.303 & 0.420 & 0.373 & - & 0.198 & 0.324 & - & 0.209 & 0.552 & - \\
\hline AR(1) Test ( $p$-value) & - & - & - & 0.055 & - & - & 0.219 & - & - & 0.105 \\
\hline AR(2) Test ( $p$-value) & - & - & - & 0.202 & - & - & 0.107 & - & - & 0.513 \\
\hline Sargan Test ( $p$-value) & - & - & - & 0.078 & - & - & 0.001 & - & - & 0.000 \\
\hline Hansen J Test (p-value) & - & - & - & 1.000 & - & - & 1.000 & - & - & 1.000 \\
\hline
\end{tabular}

Robust standard errors in parentheses. *** $\mathrm{p}<0.01, * * \mathrm{p}<0.05, * \mathrm{p}<0.1$

Notes: * Inflation rates are based on 3 year average data in Table A1.

a) Since this paper estimates the first differenced equation, country fixed effects cancel out. 
Figure A1. Trends of Average and Median REPUTATION of 62 Countries

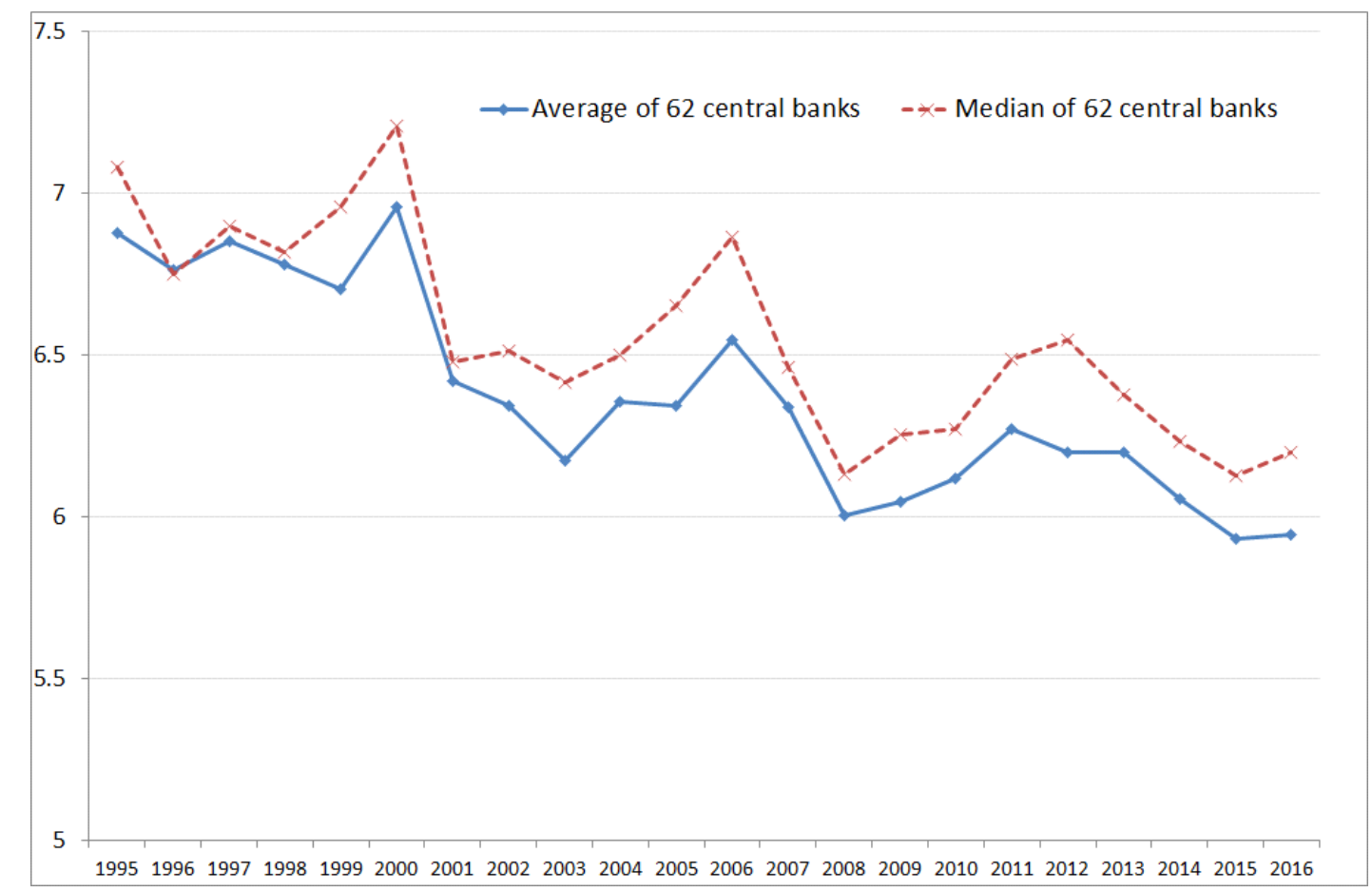

Source: IMD World Competitiveness Yearbook (1995-2016), Executive Opinion Survey on central bank policy. The data has a scale of $0-10$; high values indicate a positive perception of central bank policy. 
Figure A2. IMD Reputation Measures and Policy Rates (US \& Germany)

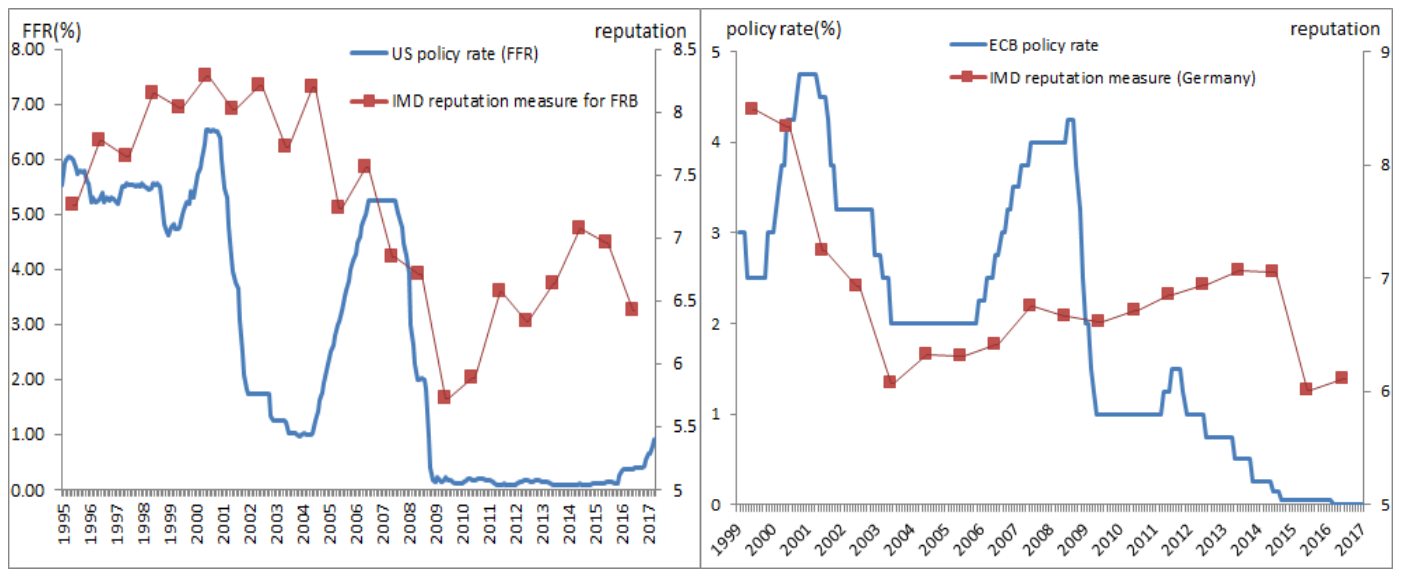

Source: IMD, St. Louis Fed, ECB

Figure A3. Central Bank Independence and Reputation Measure (IMD)

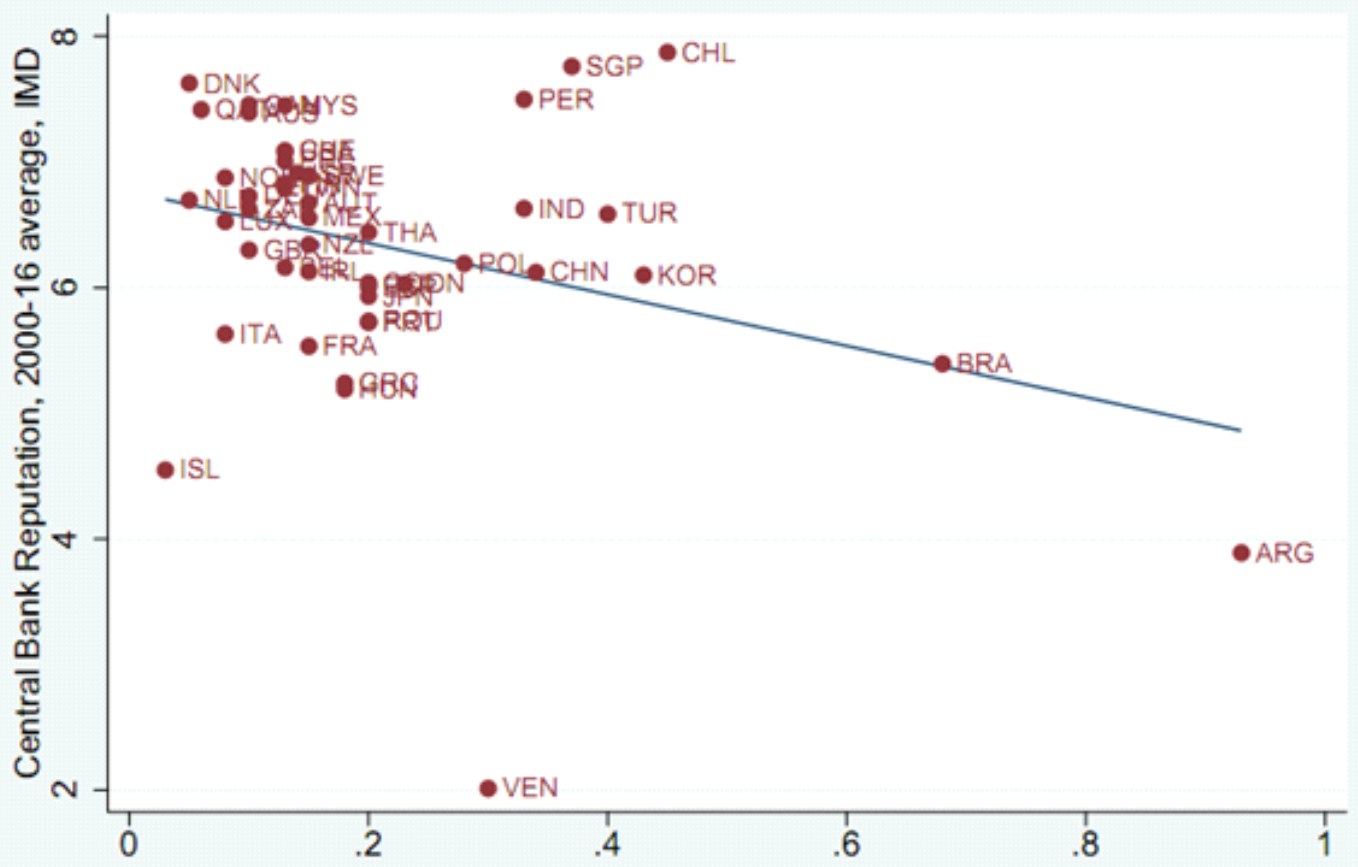

Turnover Rates of central bank governor,1950-89, Cukierman et al. 1992

Notes: High turnover rates mean frequent changes of $C B$ governors or low actual $C B$ independence. This figure illustrates that frequent changes of $C B$ governors (during 1950-89) are negatively associated with $C B$ reputation (average during 2000-16). The linear line reflects the OLS regression coefficient: REPUTATION $=6.76^{* * *}-2.05 \times$ TURNOVER_RATES $* *\left(\mathrm{~N}=46, \mathrm{R}^{2}=0.106\right)$. A median regression result, which is robust to outliers, also shows a similar outcome: REPUTATION $=6.88^{* * *}-2.18 \times$ TURNOVER_RATES** $(\mathrm{N}=46$, Pseudo $R^{2}=0.098$ ). A figure for the quantile regression result is presented in Figure $A 4$. 
Figure A4. Central Bank Independence and Reputation: Simple Quantile Regression Results

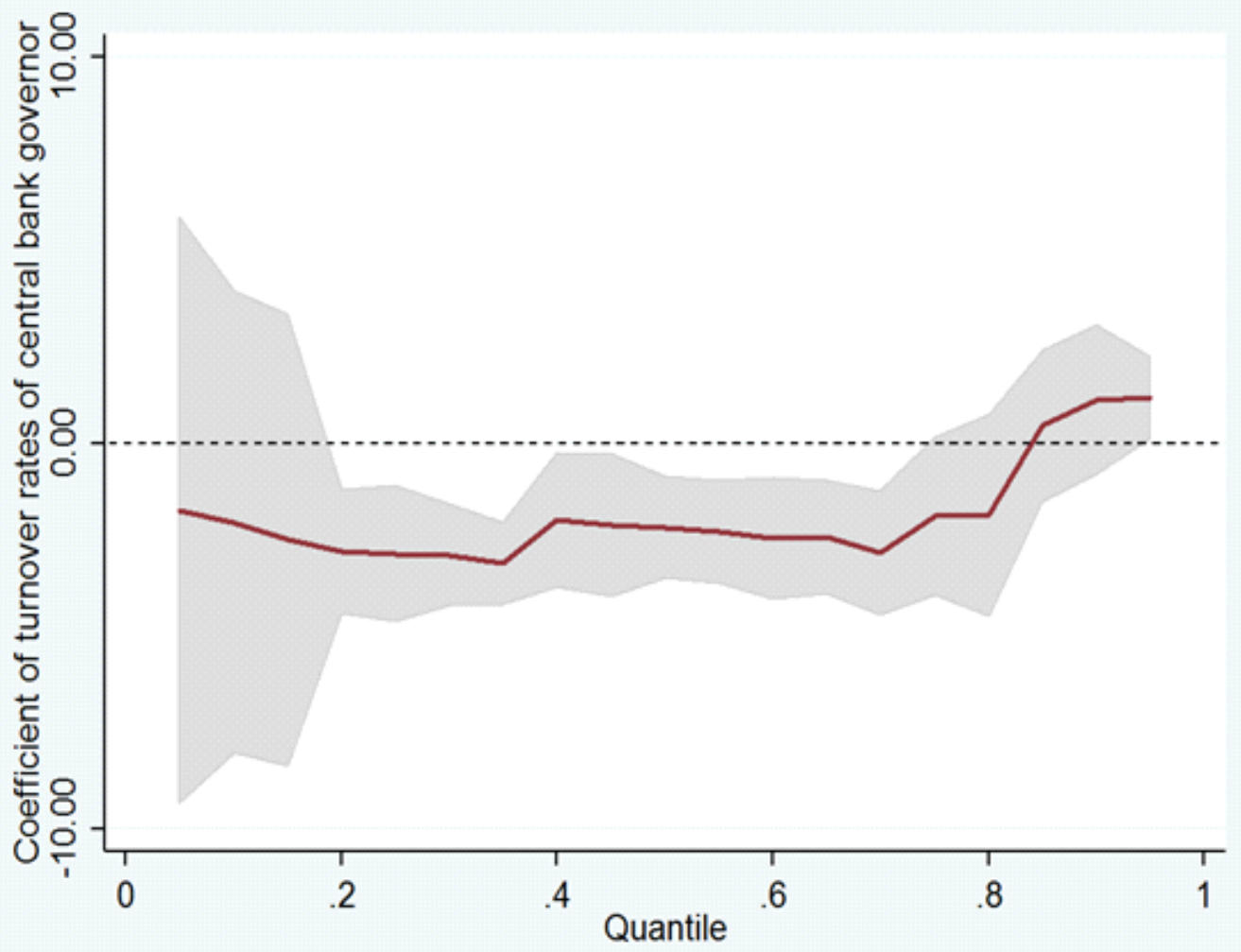

Notes: See the notes in Figure A3. This figure illustrates the quantile regression results (coefficients of turnover rates and their 95\% confidence interval) when the dependent variable is REPUTATION (2000-16), and an explanatory variable is GOVERNOR TURNOVER_RATES. It shows that turnover rates of central bank governors during 1950-89 are negatively associated with the central bank reputation measure from the IMD. 
Figure A5. Reputation and Inflation Expectations (\%)

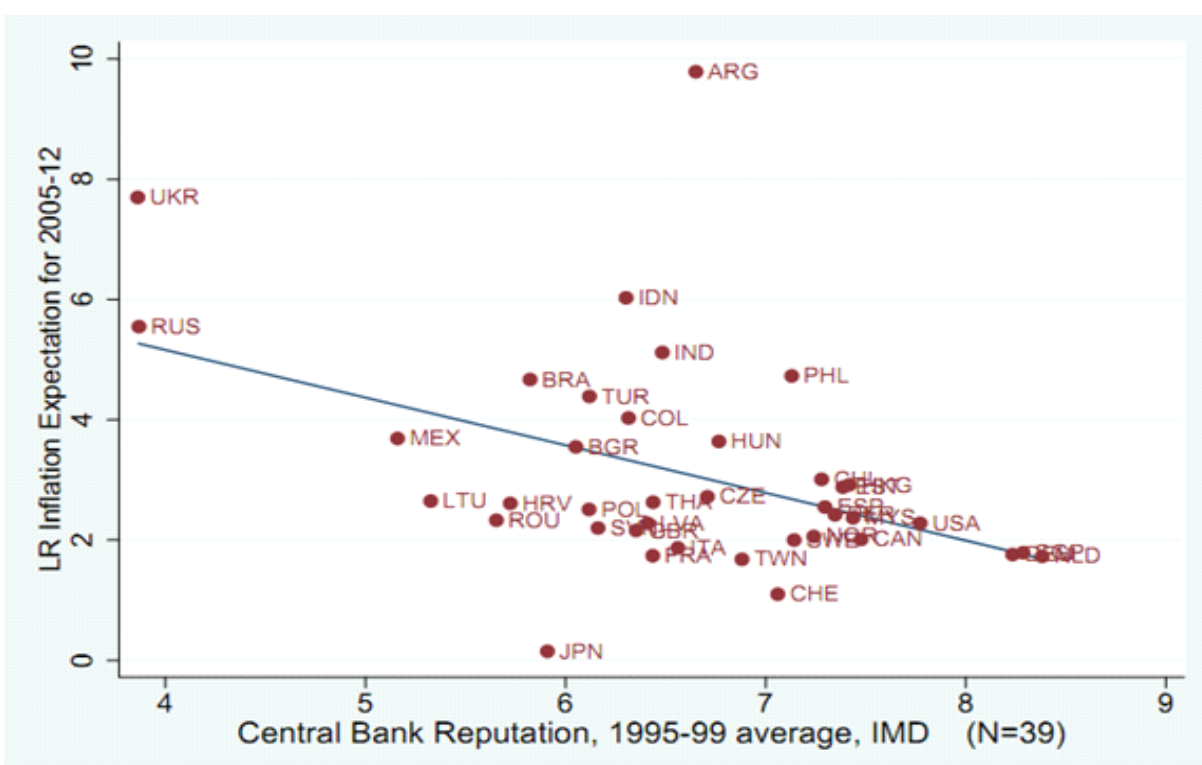

Notes: Long-run inflation expectation data are $\pi^{*}$ in the Table 2 of Mehrotra and Yetman (2014, p. 12), which is based on inflation expectations of professional forecasters of Consensus Economics. Venezuela, which is identified as an outlier by Mehrotra and Yetman, is excluded from the sample.

Figure A6. Reputation and Standard Errors of Inflation Expectations

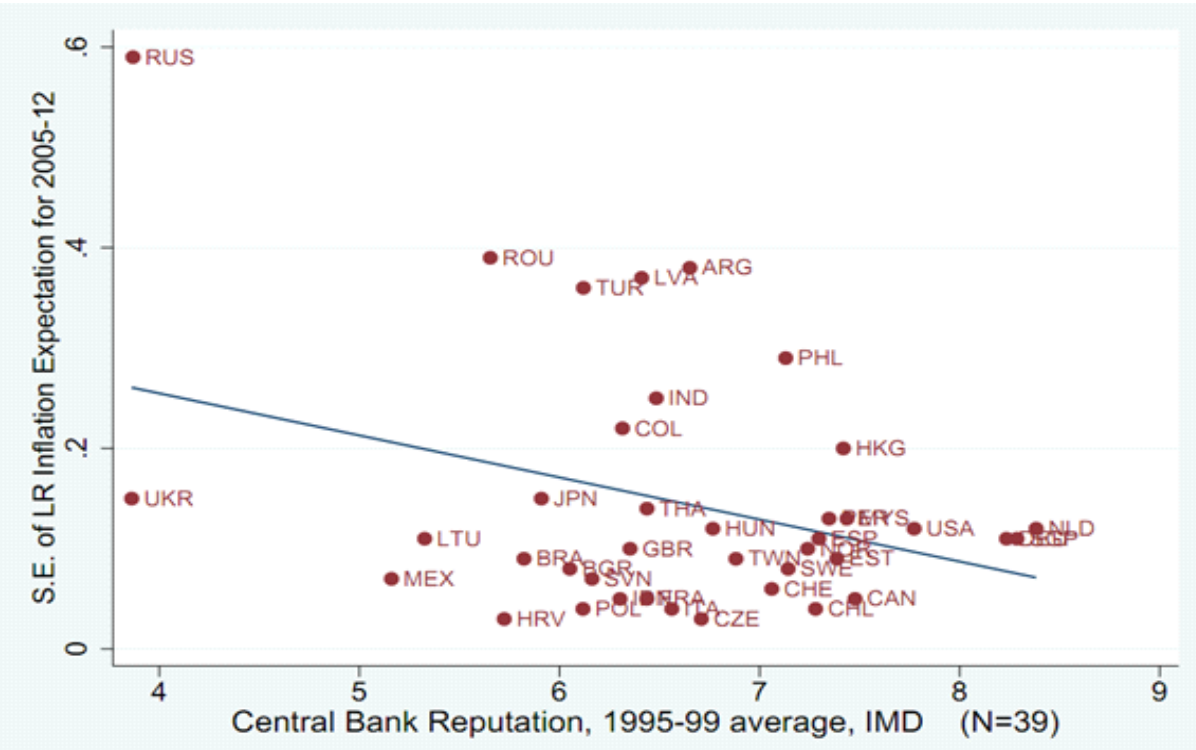

Notes: Standard Errors of long-run inflation expectation data are standard errors of estimated long-run inflation expectations $\left(\pi^{*}\right)$. (They are "s.e. $\left(\pi^{*}\right)^{\prime \prime}$ in the Table 2 of Mehrotra and Yetman (2014, p. 12)). Venezuela, which is identified as an outlier by Mehrotra and Yetman, is excluded from the sample. 


\section{$<$ Abstract in Korean $>$ \\ 중앙은행 평판과 정책 성과: 62개국 고위경영자 서베이 분석}

\section{황인도*}

Barro and Gordon의 연구 이후 중앙은행 평판과 인플레이션 성과에 관한 이 론적 연구는 많았지만, 동 관계에 관하여 엄밀하게 실증분석한 연구는 많지 않았 다. 본 논문은 중앙은행 평판에 관한 새로운 데이터 -중앙은행 정책 수행에 관해 각국 현지 경영자를 대상으로 매년 설문조사한 자료(총 62개국, 1995-2016년)-를 이용하여 중앙은행 평판이 인플레이션과 실업 성과에 미치는 영향을 실증분석 하 였다. 분석 결과 중앙은행 평판은 인플레이션을 결정하는 중요 요소의 하나인 것 으로 나타났다. 고정효과 패널 모형 및 Arellano-Bond의 차분 일반화적률법 추정 결과, 지난 20 년간 중앙은행 평판이 높은 나라는 산출갭과 실업률이 일정할 때 인 플레이션은 더 낮게 유지되는 등 더 나은 인플레이션 성과를 나타내었다. 동 결과 는 통화량 증가율, 과거 인플레이션 수준, 환율, 금융위기 더미변수 등 다양한 변 수를 추가하더라도 강건한 것으로 나타났다. 이밖에 본고는 중앙은행 평판 수준 이 인플레이션 기대의 물가목표 안착과 연관되어 있음을 보였다. 중앙은행 평판 수준이 물가의 변동성이나 실업률에 미치는 영향은 강건성이 약한 것으로 나타났 다. 본고는 또한 인플레이션 수준이 높으면 중앙은행 평판이 하락하는 역의 인과 관계도 성립한다는 증거를 발견하였다.

핵심 주제어: 평판, 신뢰, 통화정책, 기대인플레이션의 안착

JEL Classification: E31, E52, E58, N10

\footnotetext{
* 한국은행 경제연구원 미시제도연구실 연구위원(전화: 02-759-5366, E-mail: hid@bok.or.kr)

본 논문의 작성과정에서 유익한 논평과 제안을 해주신 논문 심의위원이신 송승주 전 금융통화연 구실장, 김병기 미시제도연구실장, 김기호 거시경제연구실 연구위원, 이동원 조사국 물가연구팀 과장님과 $\mathrm{BOK}$ 경제연구 외부심사위원께 감사드립니다.
} 


\section{$\mathrm{BOK}$ 경제연구 발간목록}

한국은행 경제연구원에서는 Working Paper인 『BOK 경제연구』를 수시로 발간하고 있습니다. 『BOK 경제연구』는 주요 경제 현상 및 정책 효과에 대한 직관적 설명 뿐 아니라 깊이 있는 이론 또는 실증 분석을 제공함으로써 엄밀한 논증에 초점을 두는 학술논문 형태의 연구이며 한국은행 직원 및 한국은행 연구용역사업의 연구 결과물이 수록되고 있습니다.

${ }^{\circledR B O K}$ 경제연구』는 한국은행 경제연구원 홈페이지(http://imer.bok.or.kr)에서 다운로드하여 보실 수 있습니다.

제2015-1글로벌 금융위기 이후 주요국 통화정책 운영체계의 변화

2 미국 장기시장금리 변동이 우리나라 금리기간구조에 미치는 영향 분석 및 정책적 시사점

3 직간접 무역연계성을 통한 해외충격의 우리나라 수출입 파급효과 분석

4 통화정책 효과의 지역적 차이

5 수입중간재의 비용효과를 고려한 환율변동과 수출가격 간의 관계

6 중앙은행의 정책금리 발표가 주식시장 유동성에 미치는 영향

7 은행 건전성지표의 변동요인과 거시건전성 규제의 영향

8 Price Discovery and Foreign Participation in The Republic of Korea's Government Bond Futures and Cash Markets

9 규제가 노동생산성에 미치는 영향: 한국의 산업패널 자료를 이용한 실증분석

10 인구 고령화와 정년연장 연구 (세대 간 중첩모형(OLG)을 이용한 정량 분석)

11 예측조합 및 밀도함수에 의한 소비자물가 상승률 전망

12 인플레이션 동학과 통화정책

13 Failure Risk and the Cross-Section of Hedge Fund Returns

14 Global Liquidity and Commodity Prices
김병기·김인수

강규호·오형석

최문정·김근영

김기호

김경민

이지은

강종구

Jaehun Choi · Hosung Lim • Rogelio Jr. Mercado • Cyn-Young Park

이동렬·최종일·이종한

홍재화·강태수

김현학

우준명

Jung-Min Kim

Hyunju Kang •

Bok-Keun $\mathrm{Yu}$. Jongmin $\mathrm{Yu}$ 


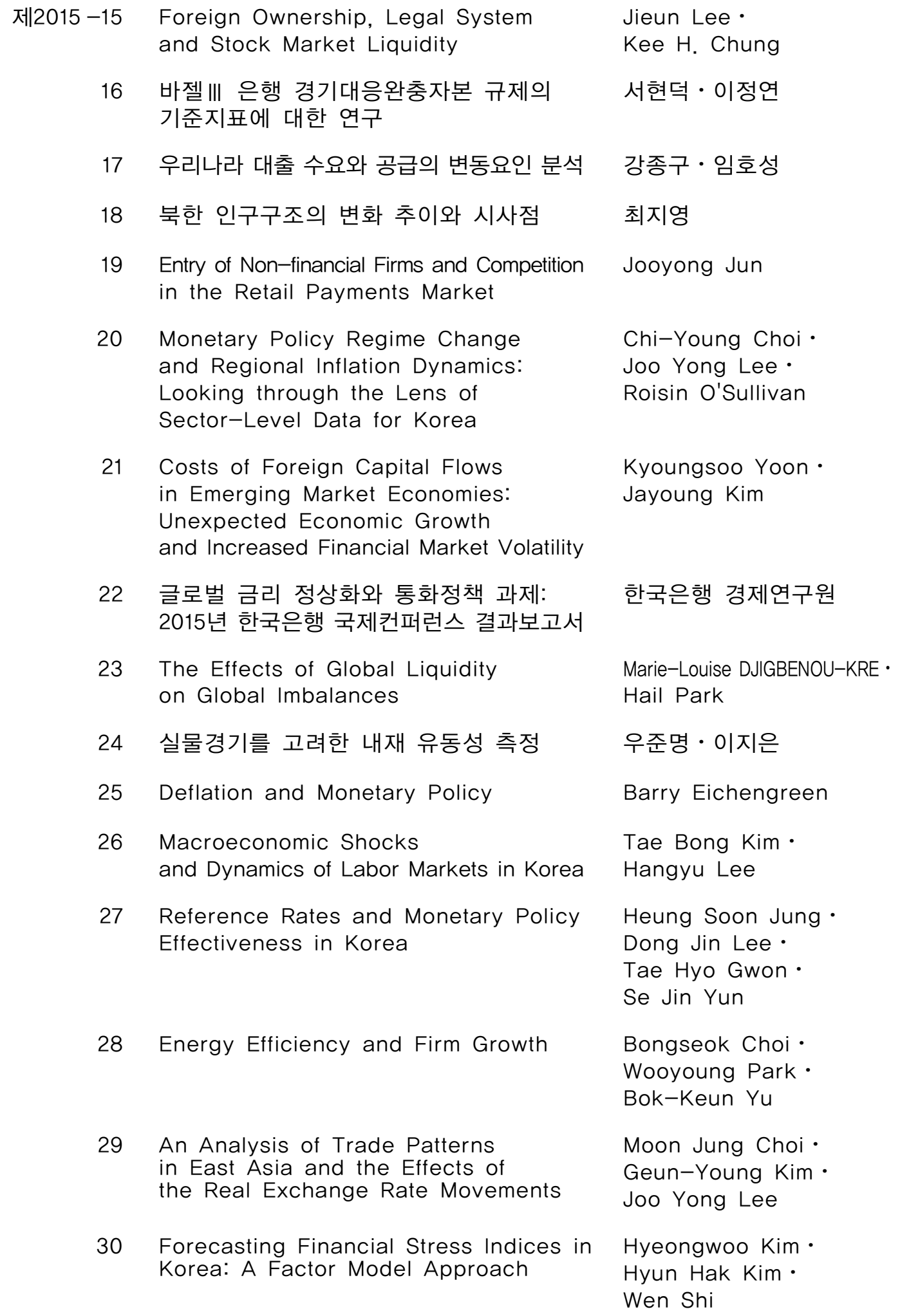

22 글로벌 금리 정상화와 통화정책 과제: 2015년 한국은행 국제컨퍼런스 결과보고서

23 The Effects of Global Liquidity on Global Imbalances

24 실물경기를 고려한 내재 유동성 측정

25 Deflation and Monetary Policy

26 Macroeconomic Shocks

and Dynamics of Labor Markets in Korea

27 Reference Rates and Monetary Policy Effectiveness in Korea

Jieun Lee $\cdot$

Kee $\mathrm{H}$. Chung

서현덕·이정연

강종구·임호성

최지영

Jooyong Jun

Chi-Young Choi

Joo Yong Lee .

Roisin O'Sullivan

Kyoungsoo Yoon • Jayoung Kim

한국은행 경제연구원

Marie-Louise DJIGBENOU-KRE -

Hail Park

우준명·이지은

Barry Eichengreen

Tae Bong Kim •

Hangyu Lee

Heung Soon Jung •

Dong Jin Lee.

Tae Hyo Gwon •

Se Jin Yun

Bongseok Choi

Wooyoung Park •

Bok-Keun Yu

Moon Jung Choi •

Geun-Young Kim •

Joo Yong Lee

Hyeongwoo Kim •

Hyun Hak Kim •

Wen Shi 
제2016-1 The Spillover Effects of U.S. Monetary

Policy on Emerging Market Economies:

Breaks, Asymmetries and Fundamentals

2 Pass-Through of Imported Input Prices to Domestic Producer Prices: Evidence from Sector-Level Data

3 Spillovers from U.S. Unconventional Monetary Policy and Its Normalization to Emerging Markets: A Capital Flow Perspective

4 Stock Returns and Mutual Fund Flows in the Korean Financial Market:

A System Approach

5 정책금리 변동이 성별·세대별 고용률에 미치는 영향

6 From Firm-level Imports to Aggregate Productivity: Evidence from Korean Manufacturing Firms Data

7 자유무역협정(FTA)이 한국 기업의 기업내 무역에 미친 효과

8 The Relation Between Monetary and Macroprudential Policy

9 조세피난처 투자자가 투자 기업 및 주식 시장에 미치는 영향

10 주택실거래 자료를 이용한 주택부문 거시 건전성 정책 효과 분석

11 Does Intra-Regional Trade Matter in Regional Stock Markets?: New Evidence from Asia-Pacific Region

12 Liability, Information, and Anti-fraud Investment in a Layered Retail Payment Structure

13 Testing the Labor Market Dualism in Korea

14 북한 이중경제 사회계정행렬 추정을 통한 비공식부문 분석
Geun-Young Kim •

Hail Park •

Peter Tillmann

JaeBin Ahn.

Chang-Gui Park •

Chanho Park

Sangwon Suh .

Byung-Soo Koo

Jaebeom Kim •

Jung-Min Kim

정성엽

JaeBin Ahn •

Moon Jung Choi

전봉걸 - 김은숙 - 이주용

Jong Ku Kang

정호성·김순호

정호성·이지은

Sei-Wan Kim •

Moon Jung Choi

Kyoung-Soo Yoon •

Jooyong Jun

Sungyup Chung •

Sunyoung Jung

최지영 


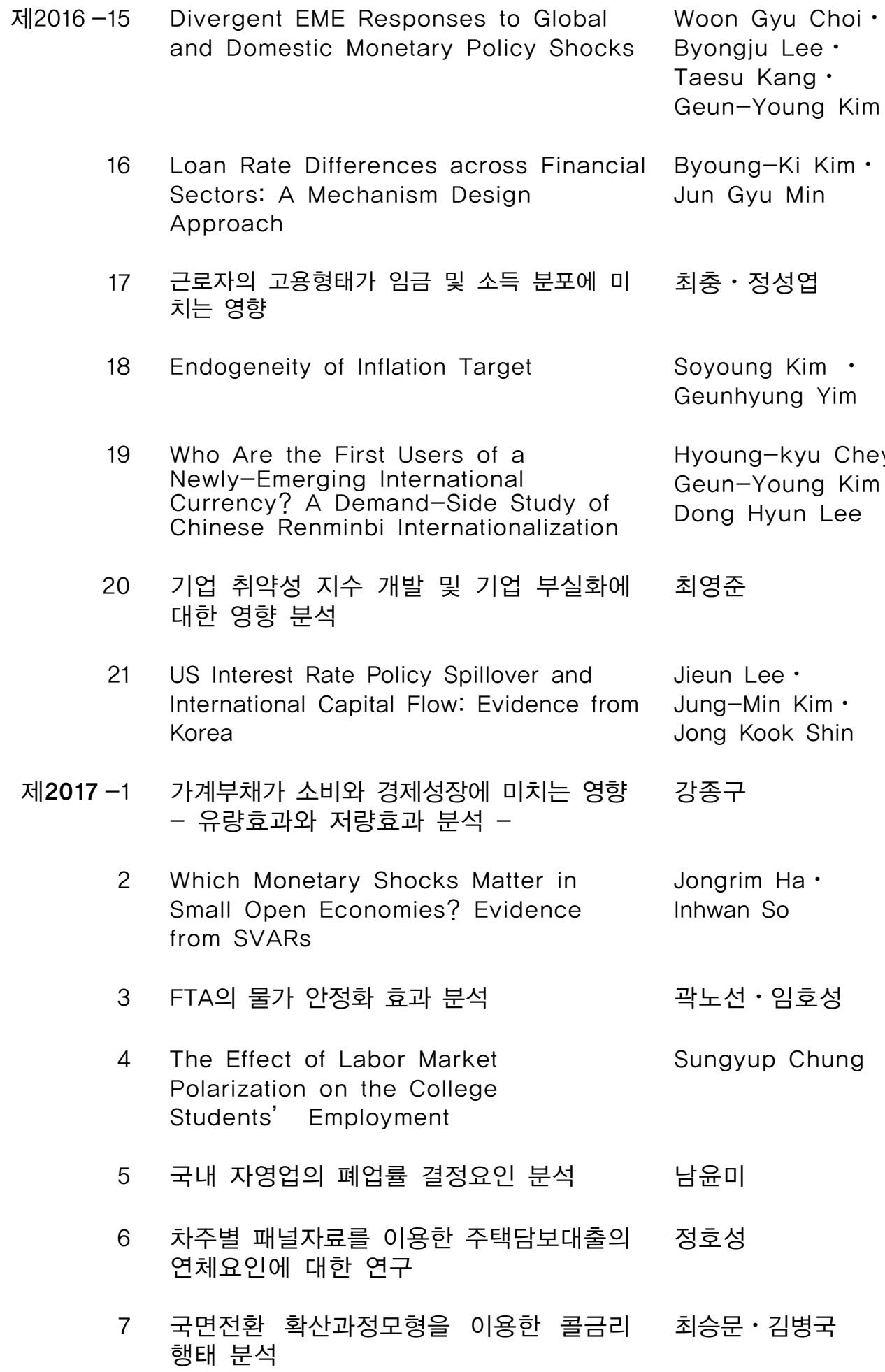

7 국면전환 확산과정모형을 이용한 콜금리 최승문-김병국 행태 분석 


\begin{tabular}{|c|c|c|}
\hline 제2017 -8 & $\begin{array}{l}\text { Behavioral Aspects of Household } \\
\text { Portfolio Choice: Effects of Loss } \\
\text { Aversion on Life Insurance Uptake } \\
\text { and Savings }\end{array}$ & In Do Hwang \\
\hline 9 & 신용공급 충격이 재화별 소비에 미치는 영향 & 김광환·최석기 \\
\hline 10 & 유가가 손익분기인플레이션에 미치는 영향 & 김진용·김준철 $\cdot$ 임형준 \\
\hline 11 & $\begin{array}{l}\text { 인구구조변화가 인플레이션의 장기 추세에 } \\
\text { 미치는 영향 }\end{array}$ & 강환구 \\
\hline 12 & $\begin{array}{l}\text { 종합적 상환여건을 반영한 과다부채 } \\
\text { 가계의 리스크 요인 분석 }\end{array}$ & 이동진·한진현 \\
\hline 13 & $\begin{array}{l}\text { Crowding out in a Dual Currency Regime? } \\
\text { Digital versus Fiat Currency }\end{array}$ & $\begin{array}{l}\text { KiHoon Hong } \cdot \\
\text { Kyounghoon Park } \\
\text { Jongmin Yu }\end{array}$ \\
\hline 14 & $\begin{array}{l}\text { Improving Forecast Accuracy of } \\
\text { Financial Vulnerability: Partial Least } \\
\text { Squares Factor Model Approach }\end{array}$ & $\begin{array}{l}\text { Hyeongwoo Kim } \\
\text { Kyunghwan Ko }\end{array}$ \\
\hline 15 & $\begin{array}{l}\text { Which Type of Trust Matters?: } \\
\text { Interpersonal vs. Institutional vs. } \\
\text { Political Trust }\end{array}$ & In Do Hwang \\
\hline 16 & 기업특성에 따른 연령별 고용행태 분석 & 이상욱·권철우·남윤미 \\
\hline 17 & $\begin{array}{l}\text { Equity Market Globalization and } \\
\text { Portfolio Rebalancing }\end{array}$ & $\begin{array}{l}\text { Kyungkeun Kim } \cdot \\
\text { Dongwon Lee }\end{array}$ \\
\hline 18 & $\begin{array}{l}\text { The Effect of Market Volatility on } \\
\text { Liquidity and Stock Returns in the } \\
\text { Korean Stock Market }\end{array}$ & Jieun Lee $\cdot \mathrm{KeeH}$.Chung \\
\hline 19 & $\begin{array}{l}\text { Using Cheap Talk to Polarize or Unify } \\
\text { a Group of Decision Makers }\end{array}$ & Daeyoung Jeong \\
\hline 20 & $\begin{array}{l}\text { 패스트트랙 기업회생절차가 법정관리 기업의 } \\
\text { 이자보상비율에 미친 영향 }\end{array}$ & 최영준 \\
\hline 21 & 인구고령화가 경제성장에 미치는 영향 & 안병권·김기호·육승환 \\
\hline 22 & $\begin{array}{l}\text { 고령화에 대응한 인구대책: OECD사례를 중심 } \\
\text { 으로 }\end{array}$ & 김진일 · 박경훈 \\
\hline
\end{tabular}




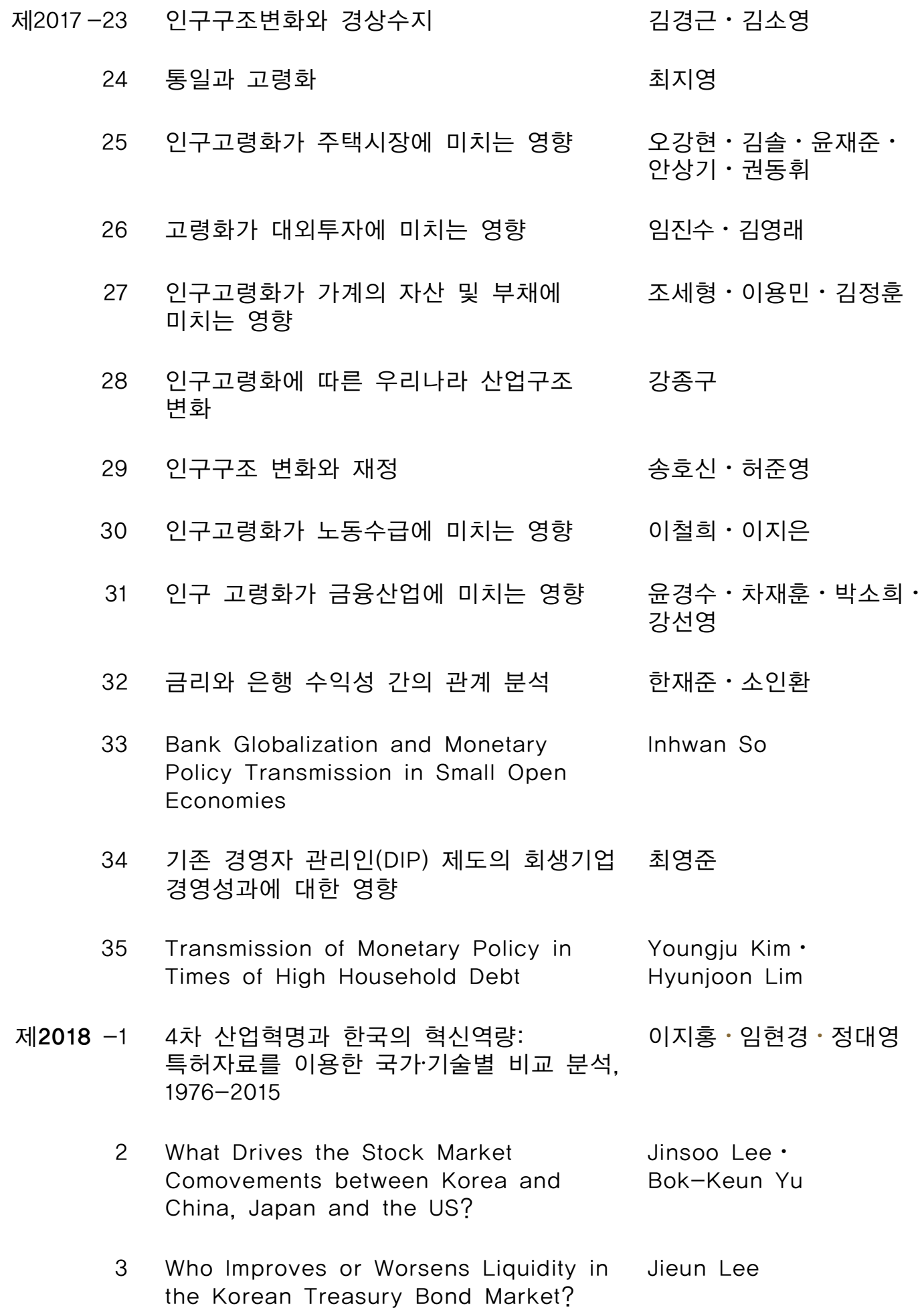

2 What Drives the Stock Market Comovements between Korea and China, Japan and the US?

3 Who Improves or Worsens Liquidity in the Korean Treasury Bond Market? 


\begin{tabular}{|c|c|c|}
\hline 제2018 -4 & $\begin{array}{l}\text { Establishment Size and Wage } \\
\text { Inequality: The Roles of Performance } \\
\text { Pay and Rent Sharing }\end{array}$ & Sang-yoon Song \\
\hline 5 & $\begin{array}{l}\text { 가계대출 부도요인 및 금융업권별 } \\
\text { 금융취약성: 자영업 차주를 중심으로 }\end{array}$ & 정호성 \\
\hline 6 & $\begin{array}{l}\text { 직업훈련이 청년취업률 제고에 미치는 } \\
\text { 영향 }\end{array}$ & 최충·김남주 · 최광성 \\
\hline 7 & 재고투자와 경기변동에 대한 동학적 분석 & 서병선·장근호 \\
\hline 8 & $\begin{array}{l}\text { Rare Disasters and Exchange Rates: } \\
\text { An Empirical Investigation of South } \\
\text { Korean Exchange Rates under Tension } \\
\text { between the Two Koreas }\end{array}$ & $\begin{array}{l}\text { Cheolbeom Park } \\
\text { Suyeon Park }\end{array}$ \\
\hline 9 & $\begin{array}{l}\text { 통화정책과 기업 설비투자 } \\
\text { - 자산가격경로와 대차대조표경로 분석 - }\end{array}$ & 박상준 · 육승환 \\
\hline 10 & $\begin{array}{l}\text { Upgrading Product Quality: } \\
\text { The Impact of Tariffs and Standards }\end{array}$ & Jihyun Eum \\
\hline 11 & 북한이탈주민의 신용행태에 관한 연구 & 정승호·민병기·김주원 \\
\hline 12 & $\begin{array}{l}\text { Uncertainty Shocks and Asymmetric } \\
\text { Dynamics in Korea: A Nonlinear } \\
\text { Approach }\end{array}$ & $\begin{array}{l}\text { Kevin Larcher } \\
\text { Jaebeom Kim } \\
\text { Youngju Kim }\end{array}$ \\
\hline 13 & $\begin{array}{l}\text { 북한경제의 대외개방에 따른 경제적 후생 } \\
\text { 변화 분석 }\end{array}$ & 정혁·최창용·최지영 \\
\hline 14 & $\begin{array}{l}\text { Central Bank Reputation and } \\
\text { Inflation-Unemployment Performance: } \\
\text { Empirical Evidence from an Executive } \\
\text { Survey of } 62 \text { Countries }\end{array}$ & In Do Hwang \\
\hline
\end{tabular}

